\title{
Bajo el signo de Aljubarrota: la parábola emblemática y caballeresca de Juan I de Castilla (1379-1390)
}

\author{
Under the Sign of Aljubarrota: Juan I of Castile's \\ Emblematic and Chivalric Parable (1379-1390)
}

\author{
Álvaro Fernández de Córdova Miralles \\ Universidad de Navarra \\ afdecordova@unav.es
}

\begin{abstract}
RESUMEN
Este artículo estudia las divisas y órdenes caballerescas surgidas durante el reinado de Juan I de Castilla (1379-1390), atendiendo a las circunstancias políticas, el ceremonial regio y la simbólica del poder desarrollados por la nueva dinastía Trastámara. De acuerdo con la política caballeresca de Enrique II, su hijo impulsó la orden de la Banda ligándola a la Corona, y enriqueció su emblemática personal con criaturas quiméricas (dragón, grifo, halcón) que proyectaban mensajes proféticos y exaltadores de su poder. La derrota de Aljubarrota (1385) supuso un punto de inflexión con la creación de las divisas del Espíritu Santo y la Rosa que intensificaron la dimensión cristiana de su caballería en el marco de la reforma militar y la renovación religiosa reactivada al final de su reinado.
\end{abstract}

Palabras clave: Divisas reales, Órdenes caballerescas, Ceremonias, Juan I de Castilla, Simbología política, Orden de la Banda, Divisa de la Paloma, Divisa de la Rosa.

\begin{abstract}
This study examines emblems and orders of chivalry that emerged during the reign of Juan I of Castile (1379-1390) within the context of political events, royal ceremony and the symbolism of power developed by the new Trastamara dynasty. Following Enrique II's chivalric program, his son fomented the Order of the Sash (Orden de la Banda) linking it to the Crown and adding to its emblems chimerical beasts (dragon, griffin, falcon) that projected prophetic and laudable messages of his power. The defeat of Aljubarrota (1385) was a turning point as new emblems were created such as that of the Holy Ghost and the Rose which emphasized the Christian dimension of his orders of chivalry in the framework of a military reform and religious renovation undertaken at the end of his reign.
\end{abstract}

Key words: Royal Emblems, Orders of Chivalry, Ceremonies, Juan I of Castile, Political Symbolism, Order of the Sash, Emblem of the Holy Spirit, Emblem of the Rose.

Sumario: 1. Introducción: emblemática y caballería en la Castilla Trastámara. 2. La disputada herencia de la Banda. 2.1. Una insignia caballeresca para un rey sin trono. 2.2. El nuevo orden de Juan I: trasformaciones ceremoniales. 2.3. La Banda de Juan I de Castilla: mutaciones caballerescas. 3. De bestias y héroes: criaturas quiméricas de una dinastía profética. 3.1. La profecía del dragón. 3.2. El grifo dorado de los Trastámara. 3.3. El halcón explayado de la conquista. 4. Una caballería reinventada en tiempo de reformas. 4.1. Los caballeros del Espíritu Santo. 4.2. Los escuderos de la Rosa. 5. Conclusiones. 


\section{INTRODUCCIÓN: EMBLEMÁTICA Y CABALLERÍA EN LA CASTILLA TRASTÁMARA}

Pocos podían imaginar que cuando se extinguía la vida de aquel rey de pequeña conplisión, e muchas dolençias aplastado por el caballo que le derribara, finalizaba uno de los períodos más creativos de la caballería y la emblemática castellana ${ }^{1}$. Una paradoja más del singular reinado de Juan I Trastámara (1379-1390), considerado un período germinal en la configuración política y representativa de la monarquía ${ }^{2}$. Aquel monarca que se presentó enfermo al campo de batalla de Aljubarrota había emprendido la compleja tarea de incorporar el nuevo lenguaje de las divisas a la simbólica de un poder ardorosamente conquistado y frágilmente asentado ${ }^{3}$. Tal proyecto no podía, no pudo, reducirse a un engranaje institucional mejor o peor armado por sus letrados. Necesitaba expresarse en el lenguaje caballeresco de aquella aristocracia que le diera la victoria y contribuyó, con sus formas de expresión y agregación, a levantar el

${ }^{1}$ Este artículo forma parte del proyecto de investigación Teología politica de las monarquías hispanas bajomedievales: un estudio comparativo (HAR2011-30265), aprobado y financiado por el Ministerio de Ciencia e Innovación del Gobierno de España. Agradecemos las sugerencias y datos aportados por Faustino Menéndez Pidal, Alfonso de Ceballos-Escalera y Gila, Eduardo Pardo de Guevara y Valdés, y Rafael Domínguez Casas sobre la emblemática castellana de esta época; las precisiones de Francisco Cañas Gálvez, y los sugestivos comentarios de Miguel Metelo de Seixas, Laurent Hablot y D'Arcy Jonathan Dacre Boulton relativos a las posibles conexiones castellanas con la restante emblemática europea. También agradezco a Esteban Iraburu y a Andrés José Murcia sus oportunas correcciones al texto. Un resumen de este trabajo con algunos desarrollos específicos en FERnÁndez de CóRdova Miralles, Los emblemas de la conquista: armas y divisas de Juan I Trastámara ante la sucesión portuguesa, "Armas e troféus. Revista de história, heráldica, genealogía e arte", (2014), pp. 229-269. La descripción de Juan I procede de la Divina retribución sobre la caída de España en tiempo del Rey Don Juan el primero (1479) del bachiller Palma; usamos la edición paleográfica de Scott WARD, Historiography, Prophecy, And Literature: Divina Retribución and its Underlying Ideological Agenda, Ph.D., Indiana University, 2009, p. 262.

${ }^{2}$ Sobre el monarca es preciso partir de los estudios de Luis SuÁrez Fernández, Historia del reinado de Juan I de Castilla. Estudio y documentos, vols. I-II, Madrid, 1977-1982; ID., Juan I de Trastámara: 1379-1390, Burgos, 1994; las cuentas recogidas por María Luisa de Villalobos y MARTínez-Pontrémuli, Las gestiones hacendísticas de Diego López de Estúñiga, camarero de Juan I (Contribución al estudio de la economía y fiscalidad castellanas bajo los primeros Trastámaras), "Hispania: Revista española de historia", 43-153 (1983), pp. 194 y 202. Una actualizada revisión bibliográfica e historiográfica en César Olivera Serrano, La Península bajo los primeros Trastámara (1350-1406), "e-Humanista. Journal of Iberian Studies": peer-reviewed electronic journal, 10 (2008), pp. 1-30 [http://www.ehumanista.ucsb. edu/volumes/volume_10/pdf/1\%20Olivera.pdf]; y las recientes y valiosas aportaciones de Francisco de Paula Cañas Gálvez, La Casa de Juan I de Castilla: aspectos domésticos y ámbitos privados de la realeza castellana a finales del siglo XIV (ca. 1370-1390), "En la España Medieval”, 34 (2011), pp. 133180; ID., Structure et organisation de la Maison du roi de Castille pendant la seconde moitié du XIVe siècle. Les majordomes et la Chambre royale de Jean Irr (1379-1390, en Les entourages princiers à la fin du Moyen Âge (A. Beauchamp, ed.), Madrid, 2013, pp. 113-129.

${ }^{3}$ Son básicos los trabajos de Luis SuÁRez Fernández, Monarquía hispana y revolución Trastámara, Madrid, 1994; Julio Valdeón Baruque, Los Trastámara. El triunfo de una dinastía bastarda Madrid, 2001; Carlos Estepa DíEz, Rebelión y rey legítimo en las luchas entre Pedro I y Enrique II, en Lucha política: condena y legitimación en la España medieval (M. I. Alfonso; J. Escalona Monge; G. Martin, coords.), Lyon, 2004, pp. 43-62. 
andamiaje político de las monarquías tardomedievales ${ }^{4}$.

Tradicionalmente relegadas al preterido rincón de los "heraldistas", el estudio de las divisas y las órdenes caballerescas ha sido recuperado en las últimas décadas por una historiografía atenta a su relación con el pensamiento político y las formas representativas del poder. Los trabajos de Michel Pastoureau, D'Arcy Jonathan Dacre Boulton, Colette Beaune, Werner Paravicini o Laurent Hablot, han despejado el panorama mostrando la importancia de estas marcas que comenzaron a difundirse entre los príncipes como consecuencia de profundas trasformaciones en la mentalidad y la identidad aristocrática a mediados del siglo $\mathrm{XIV}^{5}$. Su estudio no resulta sencillo. Exige una metodología multidisciplinar que debe integrar el discurso caballeresco, la evolución nobiliaria y los mecanismos de representación del poder, y al mismo tiempo atender a una gran variedad de fuentes que van desde la producción literaria e historiográfica (crónicas, lírica de cancionero, narrativa), a la documentación (nombramientos, privilegios reales, cuentas de la casa real), y los testimonios artísticos e iconográficos (manuscritos, sepulcros, monasterios y palacios de fundación regia).

La divisa ha sido definida como la marca propia de un individuo, o de un grupo de personas, constituida por una figura (animal, planta, objeto) acompañada o no de una sentencia (mote o lema), cuya composición y utilización no están sometidas a reglas precisas $^{6}$. Estos emblemas personales que en Francia e Inglaterra reciben el nombre

${ }^{4}$ Algunos trabajos que abordan las ricas interferencias culturales e ideológicas entre caballería y realeza a fines de la Edad Media: Luis SuÁrez Fernández, Nobleza y monarquía: entendimiento y rivalidad. El proceso de construcción de la Corona española. Madrid, 2003; Jesús Demetrio RodRíGuez VELASCO, El debate sobre la caballería en el siglo XV: la tratadística caballeresca castellana en su marco europeo, Salamanca, 1996; La chevalerie en Castille à la fin du Moyen Âge: aspects sociaux, idéologiques et imaginaires (G. Martin; A. Pérez Martín, et alii, dirs.), París, 2001; Joaquín YARZA LuACES, La nobleza ante el rey: los grandes linajes castellanos y el arte en el siglo XV, Madrid, 2003.

${ }^{5} \mathrm{Cfr}$. Michel Pastoureau, Aux origines de l'embleme: la crise de l'héraldique européenne aux XIV et XV siècles, en Emblemes et divises de la Renaissance, París, 1981, pp. 129-139; ID., Arma senescunt, insignia florescunt. Note sur les origines de l'emblème, en Figures et couleurs, París, 1986, pp. 51-57; ID., L'emblématique princière à la fin du Moyen Age, essai de lexique et de typologie, en Héraldique et emblématique de la maison de Savoie (XIVE-XVE s.), Lausanne, 1994, pp. 11-43; Colette Beaune, Costumes et pouvoir en France à la fin du Moyen Age: les devises royales vers 1400, "Revue des sciences humaines", 55 (1981), pp. 125-146; Ronald W. Lightвown, Mediaeval European Jewellery, Victoria and Albert Museum, Londres, 1992; Front Cover, Holger Kruse, Werner PARAVICINI, Andreas RANFT, Ritterorden und Adelsgesellschaften im spätmittelalterlichen Deutschland. Ein systelatisches Verzeichnis, Bern/Francfort am Main, 1991, completado en 1997; D’Arcy Jonathan Dacre Boulton, The knights of the crown: the monarchical orders of knighthood in later medieval Europe, 1325-1520, Nueva York, 2000; ID., Knighthood and Nobility in the Lay Orders and Nobiliary Societies, en As ordens militares e as ordens de cavaleria na construção do mundo ocidental. Actas do IV Encontro sobre Ordens Militares, (I. C. Ferreira Fernandes, coord.), Lisboa, 2005, pp. 643-665; y la excelente tesis de Laurent HавLот, La devise, mise en signe du prince, mise en scene du pouvoir. Les devises et l'emblématique des princes en France et en Europe à la fin du Moyen Age, vols. I-II, Université de Poitiers, 2001; véase ahora su sitio web: base-devise.edel.univ-poitiers.fr [http://base-devise.edel.univpoitiers.fr/index.php?id=1431].

${ }^{6}$ El badge o bage era una figura emblemática empleada aisladamente que no poseía la sentencia o lema que solía acompañar a la devise (divisa). Esta distinción, sin embargo, no puede mantenerse en Castilla, donde no existe el primero de estos términos, empleándose "divisa" o "devisa" para referirse a figuras emblemáticas con o sin lema. Por esta razón, en el presente trabajo usaremos el genérico "divisa" para referirnos a las dos realidades emblemáticas; sobre las precisiones terminológicas cfr. 
de bage o badges cuando no van acompañados de sentencia, servían como signos privados, insignias lúdicas, marcas de posesión $\mathrm{y}$, en periodos de enfrentamiento político, signos de reconocimiento e incorporación a la clientela de los príncipes. Grabadas inicialmente en adornos caballerescos, la divisa acabó colonizando los antiguos espacios heráldicos hasta crear un nuevo sistema semiológico que fue rápidamente asumido por el poder real. A diferencia de las armerías -que representaban el poder monárquico en su continuidad histórica- la divisa permitía referirse al titular de la Corona, subrayando la dimensión personalista del poder, quizá el "cuerpo físico" del rey según la célebre teoría de Kantorowicz, aunque también pudiera heredarse y asumir valores dinásticos como tendremos oportunidad de comprobar ${ }^{7}$. La corte castellana de fines de la Edad Media fue sensible a este proceso, y no tardó en convertirse en un laboratorio de experimentación caballeresca donde surgieron nuevas formulaciones icónicas que han sido examinadas por Faustino Menéndez Pidal, Alfonso Ceballos Escalera y Rafael Domínguez Casas, entre otros ${ }^{8}$.

Michel Pastoureau, L'art héraldique au Moyen Âge, París, 2009, pp. 213-214, y 230-231; НавLot, La devise, mise en signe du prince, ob. cit., pp. 23-35; ver también la argumentación de Boulton, The knights of the crown, ob. cit., pp. 3-5; ID., Advanced Heraldic Studies: An Introduction Part I. A New Conception of an Interdisciplinary Field of Scholarship, "Alta Studia Heraldica”, 2 (2009), pp. 1-54; ID., Advanced Heraldic Studies: An Introduction Part II. The Terminology of the Field: Its Nature, History, and Inadequacies Division A. The First Two Periods, c. 1170 - c. 1335, "Alta Studia Heraldica", 3 (2010), pp. 1-54. [ambos trabajos disponibles en la dirección: http://ash.heraldry.ca.]

7 Ernst H. Kantorowicz, Los dos cuerpos del rey: un estudio de teología política medieval, Madrid, 1985; véase su aplicación en Christian de MérIndol, Essai sur la distinction des espaces par le décor à l'époque médiévale: iconologie et topographie, en Aux marches du palais" Qu'est-ce qu'un palais médiéval? (A. A. Renoux, ed.), Le Mans, 2001, pp. 63-76; Laurent HaвLOT, Le décor emblématique chez les princes de la fin du Moyen Âge: un outil pour construire et qualifier l'espace, en Construction de l'espace au Moyen Âge: pratiques et représentation, París, 2007, pp. 147-165.

${ }^{8}$ Faustino Menéndez Pidal de Navascués, El escudo de España, Madrid, 2004, pp. 42-46, 89-98, 156-160, 192-195 y 199-216; ID., Lectura heráldica de la representación regia, "Torre de los Lujanes", 40 (1999), pp. 79-93; ID., Heráldica de la casa real de León y de Castilla (siglos XII-XVI), Madrid, 2011; Alfonso De Ceballos-Escalera y GILA, Las divisas en la heráldica castellana del siglo XV "Hidalguía", 192 (1985), pp. 665-688; Emiliano GonzÁlez DíEz, y Félix J. Martínez Llorente, El blasón heráldico de los reinos de León y Castilla, Valladolid, 2006, pp. 222-254; Rafael Marcos Domínguez CAsas, Las divisas reales: estética y propaganda, en Isabel La Católica y su época (L. A. Ribot García; J. VALDEón Baruque; E. Maza Zorrilla, coords.), vol. 1, Valladolid, 2007, pp. 335-360; desde la literatura Alberto Montaner Frutos, Emblemática caballeresca e identidad del caballero, en Libros de caballerías (de «Amadís» al "Quijote»). Poética, lectura, representación e identidad (E. V. Carro Carvajal, L. Puerto Moro; M. SÁnchez Pérez, eds.), Salamanca, 2002, pp. 267-306; interesantes reflexiones desde la semántica del poder en David Nogales Rincón, La significación política de la emblemática real en los albores de la Edad Moderna (1418-1518). Emblemas reales y nueva Historia política, en Imagen y cultura. La interpretación de las imágenes como Historia cultural, vol. II, Valencia, 2008, pp. 11891206; Álvaro FERNÁNDEZ De CóRdova Miralles, Las divisas del rey: escamas y ristres en la corte de Juan II de Castilla (1405-1454), "Reales Sitios", 191 (2012), pp. 22-37; ID., Los emblemas de la conquista, op cit., pp. 229-269; ID., "El emblema de la Banda entre la identidad dinástica y la pugna política en la Castilla bajomedieval (c. 1366-1454)", Emblemata. Revista Aragonesa de Emblemática (en prensa); ID., El cordón y la piña: signos regios e innovación emblemática en tiempos de Enrique III y Catalina de Lancaster (1390-1418) (en preparación); para el espacio aragonés cfr. Guillermo Joaquín de OsMA, Las divisas del Rey en los pavimentos de 'obra de Manises' del Castillo de Nápoles (años 1446-1458), Madrid, 1912, pp. 38-86; Juan Vicente García Marsilla, El poder visible. Demanda y funciones del arte en la corte de Alfonso el Magnánimo, "Ars Longa, Cuadernos de Arte", 7-8 (1996-1997), pp. 3347; Jaume Riera i Sans, J., Els heralds i les divises del rei Marti (1356-1410), "Paratge", 14 (2002), 
Poco sabemos sobre los orígenes de este proceso en el que las divisas, de simples marcas aisladas, acabaron uniéndose a las armerías y llegaron a relegarlas a un segundo plano en tiempos de los Reyes Católicos ${ }^{9}$. Este trabajo pretende explorar su período fundacional, que arranca con la traumática experiencia de una guerra civil (1366-1369) y se extiende al reinado de Juan I (1379-1390): treinta años en que la nueva dinastía restauró el patrimonio caballeresco de Alfonso XI para reinventar después su propia caballería con nuevos signos emblemáticos y formas clientelares de agregación. La batalla de Aljubarrota (1385) marca el punto de inflexión de este proceso creativo al desencadenar una serie de mutaciones simbólicas que modificaron el rostro de la monarquía. El objetivo de estas páginas es reconstruir su historia.

\section{LA DISPUTADA HERENCIA DE LA BANDA}

\subsection{UNA INSIGNIA CABALLERESCA PARA UN REY SIN TRONO}

La política caballeresca de Enrique II (1367-1379) está ligada a la tradición heredada de su padre Alfonso XI, que proporcionaba valiosos elementos de continuidad para legitimar su traumático acceso al trono ${ }^{10}$. Entre éstos se halla la

pp. 41-61; Francesca Español Bertran, El salterio y libro de horas de Alfonso el Magnánimo y el cardenal Joan de Casanova, "Locus Amoenus", 6 (2002-2003), pp. 109-111; Joan Domenge MesquidA, Regalos suntuarios: Jean de Berry y las cortes hispanas, en El intercambio artístico entre los reinos hispanos y las cortes europeas en la baja Edad Medi Media (M. C. Cosmen Alonso; M. V. Herráez Ortega; M. Pellón Gómez-Calcerrada, coords.), León, 2009, pp. 343-364; María Narbona Cárceles, Le contenu spirituel des devises princieres: le cas de Marie de Castille, reine d'Aragon (1416-1458), en International Medieval Congress. Medieval Heraldry Revisited, III. Leeds, 1 Juillet 2013 (en prensa) agradezco a su autora la consulta del trabajo antes de su publicación. Para el reino de Navarra cfr. Mikel Ramos Aguirre, Ornamentos paraheráldicos de la casa real de Navarra, "Boletín de la Real Academia Matritense de Heráldica y Genealogía", 3 (1993-1994), pp. 109-124; ID., Cimeras, colores, divisas, en Signos de identidad histórica para Navarra, vol. I, Pamplona, 1996, pp. 361-374; María NARBona CÁrCeles, Le roi de la Bonne Foy: Charles III le Noble (1387-1425) et les devises des Navarre-Évreux au XVé siècle, en Signes et couleurs des identités politiques du Moyen Âge à nos jours (D. TURREL; M. Aurell; Ch. Manigand, eds.), Rennes, 2008, pp. 477-509; ID., ;Ay!... las divisas de Carlos de Évreux, Príncipe de Viana (1421-1461), "Príncipe de Viana", 253 (2011), pp. 357-374.

${ }^{9}$ La bibliografía se ha concentrado en el final de este proceso aunque no faltan lagunas que colmar ni interpretaciones que conciliar: Juan Antonio GonzÁlez Iglesias, El humanista y los príncipes: Antonio de Nebrija, inventor de las empresas heráldicas de los Reyes Católicos, en Antonio de Nebrija: Edad Media y Renacimiento (J. A. GonzÁlez Iglesias; C. Codoñer, eds), Salamanca, 1994, pp. 5976; Juan Gil, Los emblemas de los Reyes Católicos, en Humanismo y pervivencia del mundo clásico. Homenaje al Profesor Luis Gil (J. M. Maestre Maestre; J. Pascual Barea; L. Charlo Brea, eds.), vol. II, Cádiz, 1997, pp. 385-398; José Luis Mingote Calderón, Los orígenes del yugo como divisa de Fernando el Católico: la presencia de yugos para tres animales en la iconografía, Zaragoza, 2005; Ana Isabel Carrasco Manchado, El armorial moralizado de Antonio García de Villalpando: heráldica y propaganda de los Reyes Católicos, en Estudios de genealogía, heráldica y nobiliaria (M. Á. LADERO QuesADA, coord.), Madrid, 2006, pp. 113-130.

${ }^{10}$ Frente al gobierno de Pedro I, apoyado en sectores como la mediana y pequeña nobleza, judíos y burgueses, se ha dicho que Enrique de Trastámara representaba la continuidad en las estructuras sociales, especialmente el mantenimiento de la alta nobleza que encarnaba los valores caballerescos; véanse los trabajos citados de Luis Suárez, Julio Valdeón, y Carlos Estepa. 


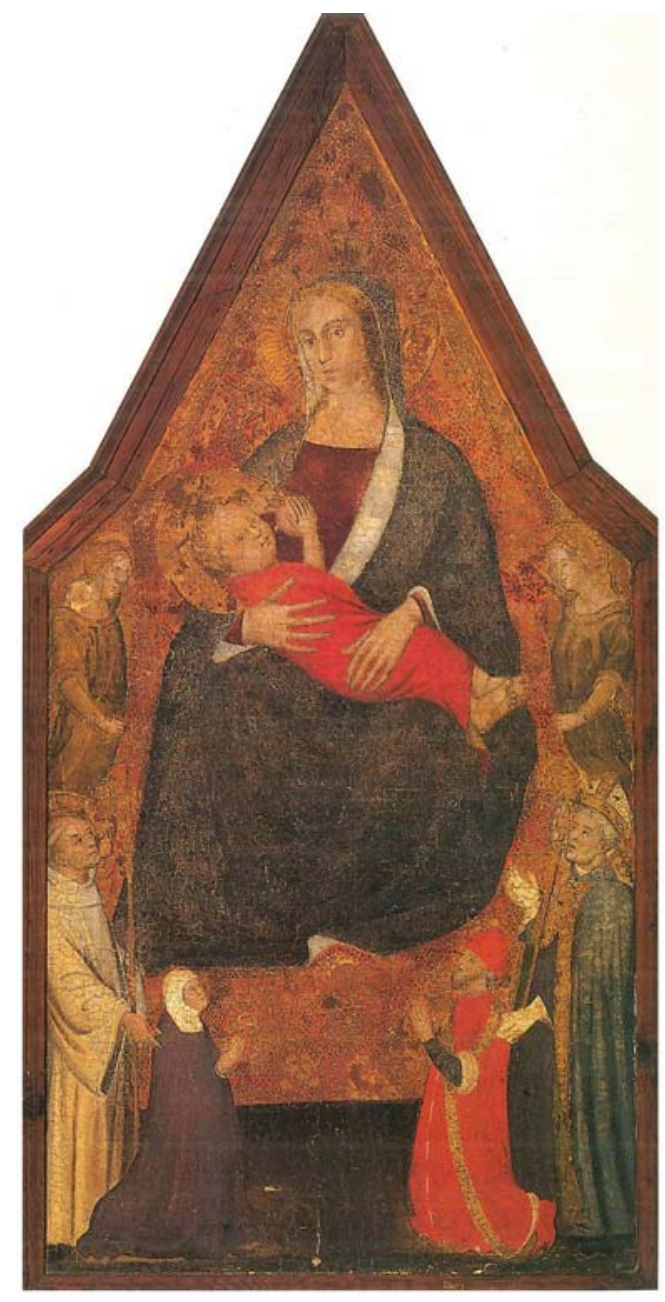

Fig. 1: Alfonso Fernández de Montemayor -vestido con túnica roja y banda dorada-como donante, junto a su esposa. Políptico de la Virgen de la leche (c. 1368-1390). Tabla central. Museo diocesano. Córdoba. orden de la Banda, considerada por Boulton la primera orden laica y monárquica del Occidente Europeo ${ }^{11}$. Para Alfonso XI la Banda supuso un exitoso experimento caballeresco para promocionar a determinados grupos urbanos con que formar un nuevo entramado cortesano frente a la nobleza rebelde ${ }^{12}$; de ahí que exigiera para el ingreso el vínculo político-feudal (vasallaje), y no el caballeresco (investidura), de acuerdo al valor nuclear de la lealtad en sus constituciones y la concepción de la orden como una extensión del cuerpo del rey. A finales del reinado de Alfonso XI y coincidiendo con la reactivación de la campaña reconquistadora, la orden sufrió profundas transformaciones con la elaboración de un reglamento, el impulso de una política restrictiva y la fijación de su heráldica y su representación figurativa: los dragantes o cabezas de dragones que muerden la banda en sus extremos, y la alteración de sus colores, banda dorada en campo de gules (rojo) que complementaba o sustituía la banda de sable (negra) en campo de plata (blanco $)^{13}$.

El conflicto sucesorio entre Pedro I y su hermanastro Enrique de Trastámara afectó a los miembros de la orden y a su representación heráldica. El primero invocó su

11 Boulton, Knighthood and Nobility, ob. cit., p. 646. Sobre la orden de la Banda cfr. Isabel GARcíA DíAz, La orden de la Banda, "Archivum Historicum Societatis Iesu", 60 (1991), pp. 29-89; Alfonso de Ceballos-Escalera y Gila, La orden y divisa de la Banda Real de Castilla, Madrid, 1993, pp. 93-95; Jesús Demetrio Rodríguez Velasco, Ciudadanía, soberanía monárquica y caballería. Poética del orden de caballería, Madrid, 2009. Para mayores indicaciones bibliográficas remitimos a nuestro trabajo El emblema de la Banda, ob. cit..

12 Isabel García DíAz, La política caballeresca de Alfonso XI, "Miscelánea Medieval Murciana", 11 (1984), pp. 117-133; Fernando Gómez Redondo, Historia de la prosa medieval castellana, II. El desarrollo de los géneros. La ficción caballeresca y el orden religioso, Madrid, 1999, pp. 1273-1274.

13 Sobre esta compleja evolución remitimos a nuestro trabajo citado. 
prestigio en los escudos que decoran los alcázares de Carmona y Sevilla (1364-1366), antes de que su rival desplegara el pendón de la Banda con un sentido legitimador (1366-1369). Ambos contendientes usaron la insignia como signo de fidelidad personal, y probablemente distinguieron sus esmaltes: Pedro I debió conservar la banda negra de los orígenes, y su hermanastro la banda dorada que usara su padre en la campaña de Salado, y porta Alfonso Fernández de Montemayor, defensor de Enrique II en Córdoba (1367), en el Políptico de la Virgen de la Leche (1368-1390) conservado en la capilla de San Pedro de la catedral cordobesa (Fig. 1).

En su deseo por atraerse fidelidades ambos contendientes entregaron la insignia a riesgo de forzar sus estatutos. Pedro I la otorgó a no cristianos como Muhammad V de Granada por su auxilio militar en la década de $1360^{14}$, y también a judíos, como proclamaba la propaganda Trastamarista ${ }^{15}$. Por su parte, Enrique aprovechó el reclamo de la orden para atraerse a la aristocracia que había abandonado a su hermanastro ${ }^{16}$. De ahí que no apelara a las leyes sucesorias para legitimar su ascenso al trono, sino a las fidelidades caballerescas y a la comunidad como delegada de Dios para designar al soberano ${ }^{17}$. Así lo refleja la secuencia ritual de su proclamación por los nobles en Calahorra (16.III.1366) y su posterior coronación en Burgos por los obispos tras su entrada en la ciudad (5.IV.1366) ${ }^{18}$. La primera ceremonia fue solicitada por sus tropas

${ }^{14}$ Muhammad V debió recibir la insignia hacia 1360, añadiendo a la banda la inscripción árabe Sólo Dios es vencedor (Wa-lū gālib illà llāhh), tal y como se aprecia en las construcciones del rey nazarí posteriores a 1362 en Granada y en la Alhambra, en azulejos vidriados del paño, la alfombra del centro del suelo del Salón de Comares, etc; y ello sin olvidar las representaciones heráldicas de la Banda castellana - con o sin dragantes- entre leones coronados, como sucede en la bóveda de la Sala de Justicia de la Alhambra y en algunos tejidos nazaríes tardíos; Florence LewIs MAY, Silk Textiles of Spain. Eighth to Fifteenth Century, Nueva York, 1957, fig. 115; Basilio Pavón Maldonado, Escudos y reyes en el Cuarto de los Leones de la Alhambra, "Al-Andalus", 35-1 (1970), pp. 179-198; ID., Notas sobre el escudo de la Orden de la Banda en los palacios de don Pedro y de Muhammad V, "Al-Andalus", 37-1 (1972), pp. 229-232; ID., Nuevas aproximaciones, ob. cit., pp. 174-176; otros autores han documentado escudos con la banda nazarí en edificaciones construidas antes de la fundación de la orden castellana; Balbina Martínez CAVIró, Los motivos decorativos, ob. cit., pp. 174-179.

${ }^{15}$ Las acusaciones contra Pedro I de adulterar los estatutos al admitir a judíos en Thomas GraY, Scalacronica, ed. H. Maxwell, Glasgow, 1908, p. 163.

16 Julio Valdeón Baruque, Enrique II, 1369-1379, Palencia, 1996, pp. 113-136.

${ }^{17}$ Joaquín Gimeno Casalduero, La imagen del monarca en la Castilla del siglo XIV: Pedro el Cruel, Enrique II y Juan I, Madrid, 1972, pp. 109-110.

${ }_{18}$ Enrique II se coronó y celebró el besamanos de honda tradición feudal, sin recurrir a la autocoronación inaugurada por Alfonso XI y demasiado "heterodoxa" para respaldar su frágil sucesión. El relato de los hechos en LóPEZ DE AyAla, Crónica de Pedro I, año 1366, cap. 3, p. 538; cap. VII, pp. 540-541; Gonzalo de Hinojosa, Continuación de la crónica de España del arzobispo Don Rodrigo Jiménez de Rada, en Colección de documentos inéditos para la Historia de España, vol. 106, Madrid, 1893, pp. 83-84; y las crónicas de Jean Froissart y Fernão Lopes que más adelante comentaremos. Véase también el comentario de Julio Valdeón Baruque, Enrique II de Castilla: la guerra civil y la consolidación del régimen (1366-1371), Valladolid, 1966, pp. 102-105; ID., Pedro I, el Cruel y Enrique de Trastámara: ¿la primera guerra civil española?, Madrid, 2002, pp. 139-144. El ritual de la autocoronación de Alfonso XI ha sido examinado e interpretado de diversas maneras por María del Pilar Ramos Vicent, Reafirmación del poder monárquico en Castilla: la coronación de Alfonso XI, Madrid, 1983; Peter Linehan, The mechanization of ritual: Alfonso XI of Castile in 1332, en Ritti e rituali nelle società medievali (J. Chiffoleau, L. Martines, A. PARAvicini Bagliani, eds.), Spoleto, 1994, pp. 309-327; ID, Historia e historiadores de la España medieval, Salamanca, 2012, pp. 583-634; José 
al ocupar la ciudad riojana y se caracterizó por el alzamiento del rey ${ }^{19}$ y la exhibición del pendón real con el grito ritual "Real, real, por el rey don Enrique"; exclamación que -según Jean Froissart- se repitió en otros enclaves del reino con formulaciones análogas: "Vive Henri, et muire dans Pierres qui nous a esté si cruels et si pervers!"20.

Desde Calahorra el nuevo monarca escribió a las ciudades explicando que los nobles le habían ofrecido la corona ${ }^{21}$, apelando a la concepción electiva de su poder que también impregna el ritual de la coronación burgalesa. Aunque en esta ceremonia se buscara la referencia de Alfonso XI, coronado en el monasterio de las Huelgas, no faltaron detalles expresivos de la influencia de los grandes ${ }^{22}$. Se escogió la fiesta de la Resurrección situando la exaltación regia en el marco del triunfo de Jesucristo sobre la muerte; mientras el cenobio de la Huelgas remitía a la más rancia tradición castellana como monasterio "fundado por los Reyes Castilla" que Enrique acondicionó con "muy grandes aparejos".

López de Ayala escribió que "coronóse alli por Rey", y Pedro Gómez Álvarez de Albornoz enfatiza que fue "cum multa gloria coronatus" 23 . Este acento sobre la solemnidad ritual no debe extrañar en una ceremonia efectuada por los prelados ante el altar de la iglesia, pues el mismo rey recordaba en 1471 la "onrra de coronamiento [...] que nos reçebimos en el altar de Sancta Maria la Real del dicho nuestro monesterio"24. El acto ha quedado inmortalizado en dos miniaturas de sendos manuscritos de la crónica de Jean Froissart: la de Arsenal 5190 (f. 100r), y la de Harley 4379 (f. 112v). En esta última composición realizada hacia 1470-1475 se representa al rey sentado en un trono muy elevado sobre un estrado y bajo dosel, en el momento en que recibe la corona de dos obispos que le bendicen al mismo tiempo (Fig. 2) ${ }^{25}$. El aislamiento de Enrique II subraya la magestad regia, mientras el resto de los cortesanos desfilan en procesión en el nivel inferior del estrado portando las insignias reales (regalia): espada, yelmo coronado, escudo con las armas reales,

Manuel Nieto Soria, La monarquía como conflicto de legitimidades, en La monarquía como conflicto en la Corona castellano-leonesa (c. 1230-1504) (J. M. NiETo SoRIA, coord.), Madrid, 2006, pp. 37-42. Una visión general de las autocoronaciones en Jaume Aurell, The Self-Coronation of Iberian Kings: A Crooked Line, "Imago temporis: medium aevum" (agradezco al autor la consulta de este trabajo en fase de publicación).

${ }^{19}$ Así lo dice el cronista portugués: "foy alçado entaõ por Rey"; Fernão Lopes, Chronica de El-Rei D. Pedro I, ed. de J. Pereira Bayam, Lisboa, 1735, p. 340.

${ }^{20}$ Jean Froissart, Chroniques, ed. de K. de Lettenhove, vol. VII, Bruselas, 1867-1877, pp. 92-93.

${ }^{21}$ Ibidem, vol. VII, p. 500.

22 Sobre las circunstancias en que se produjo cfr. Julio VAldeón Baruque, Pedro I, el Cruel y Enrique de Trastámara: ¿la primera guerra civil española?, Madrid, 2002, pp. 143-144

${ }^{23}$ Valdeón Baruque, Enrique II de Castilla: la guerra civil, ob. cit., p. 104.

${ }^{24}$ Se trata de una donación de rentas al monasterio datada en 1371; Archivo del Hospital del Rey (Burgos), leg. 3, n. 97; cfr. Amancio Rodríguez LóPEz, El Real Monasterio de las Huelgas de Burgos y el Hospital del Rey (apuntes para su historia y colección diplomática con ellos relacionada), Burgos, 1907, p. 241.

${ }^{25}$ El obispo situado a la derecha del rey le coloca la corona con su mano izquierda mientras le bendice con la derecha, mientras el otro prelado situado a la izquierda sostiene un libro (ritual) con la izquierda y le bendice con la derecha; Jean FroIssart, Chroniques; British Library (Londres); Harley 4379, f. 112v; una reproducción en Julio VALdeón BaruQue, La dinastía de los Trastámara, Madrid, 2006, p. 27. Véase el análisis de Martin NeJedLy, La Representation des pouvoirs et des hiérarchies dans les Chroniques de Jean Froissart, Villeneuve d'Ascq, 1999, pp. 88-90 y 126-128. 


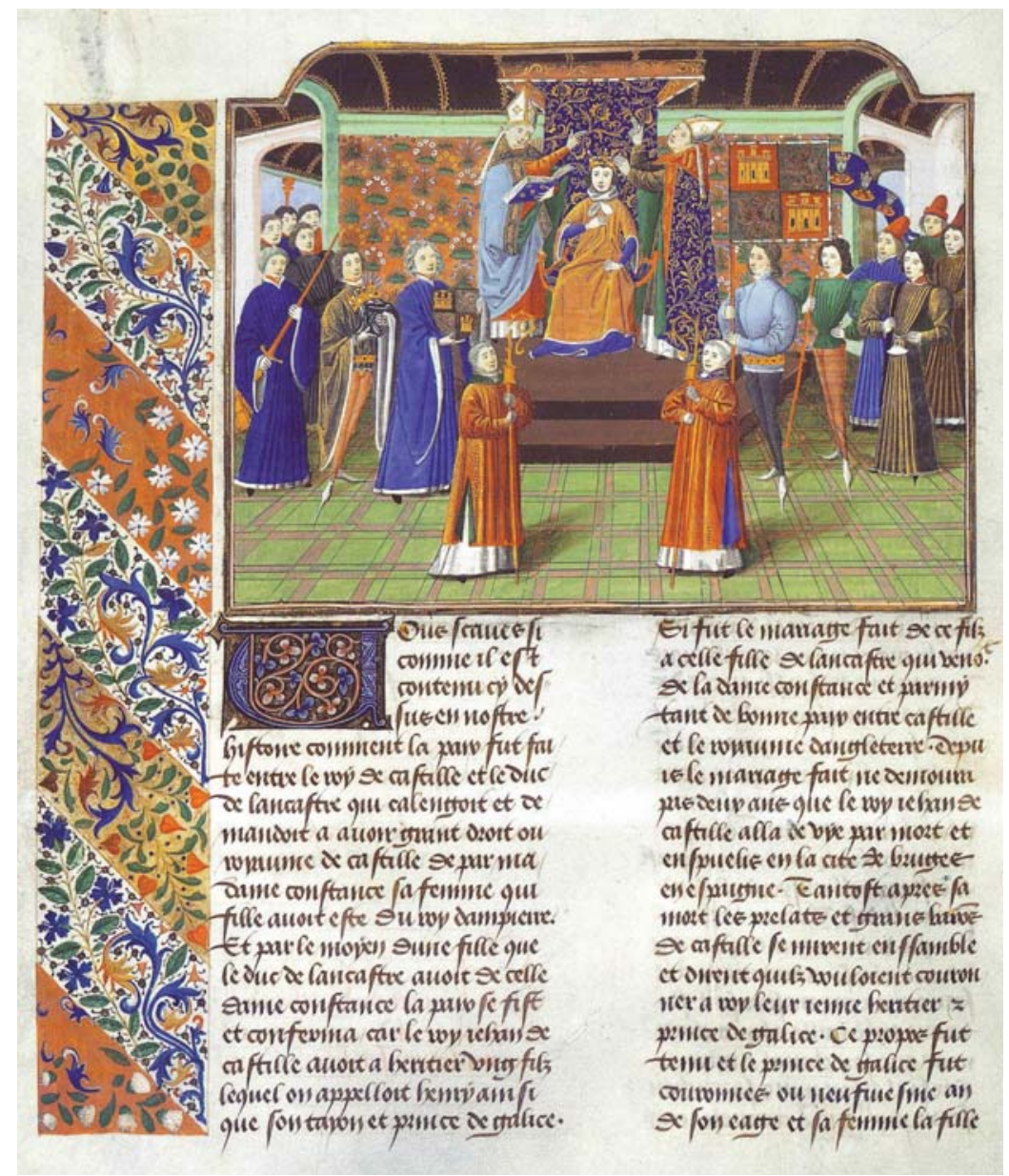

Fig. 2: Coronación del rey Enrique II de Castilla, miniatura del maestro de Harley (c. 1470-1475) en Jean Froissart, Chroniques; British Library (Londres); Harley 4379 , f. $112 \mathrm{v}$.

pendón real, y una curiosa enseña con tres rostros de reyes que podría constituir una especie de legitimación icónico-genealógica ${ }^{26}$.

Aunque se trate de una representación estereotipada y tardía, la miniatura expresa correctamente la participación aristocrática que señala Froissart y no el cronista castellano, al referirse a los nobles que "le couronnèrent à roy et le fissent tout féaulté et hommaige, et le tinrent a seigneur, et li jurèrent, présent li chevalier de Franche

${ }^{26}$ Podría tratarse de un interesante antecedente de otras manifestaciones genealógicas desarrolladas posteriomente en la corte Trastámara; David Nogales Rincón, Cultura visual y genealogía en la corte regia de Castilla durante la segunda mitad del siglo XV, e-Spania [En línea], 11 | junio 2011, puesto en línea lel 16 julio 2011, consultado el 16 juin 2013. URL : http://e-spania.revues.org/20362 ; DOI : 10.4000/e-spania.20362. 
et d'Engleterre"27. El altar del que hablara Enrique II ha quedado eclipsado en la miniatura por el estrado para enfatizar la centralidad de un rey escoltado por sus nobles y eclesiásticos. La escenificación no puede ser más elocuente del poder de la nobleza sobre unas insignias que tres décadas antes Alfonso XI había tomado directamente del altar. Su bastardo Enrique no estaba en condiciones de repetir aquel gesto inédito y tuvo que apelar a la antigua tradición castellana clausurando la ceremonia con el besamanos de los caballeros y las autoridades urbanas ${ }^{28}$.

La restauración del orden antiguo impulsado por Enrique II explica el recurso a la orden de la Banda fundada por su padre y convertida en alveolo caballeresco de la nueva monarquía. El primer Trastámara institucionalizó el oficio de alférez del pendón de la Banda vinculándolo al linaje de los López de Ayala ${ }^{29}$, y sus caballeros se convirtieron en principal fuerza de choque ocupando la vanguardia de sus tropas en la batalla de Nájera (1367) junto a los compañías franco-bretonas de Beltrán du Guesclin $^{30}$. En su esfuerzo por captar fidelidades, Enrique usó la insignia de la orden más allá de los límites prescritos concediéndola a caballeros no castellanos como la familia de los Luna que encontraron ciertas resistencias para exhibirla en Aragón. En 1367 el infante Juan (I) concedió su divisa personal a Pedro de Luna con la condición de no portar la Banda sin licencia real ${ }^{31}$; premisa que Álvaro Martínez de Luna consideró tan inaceptable que se despojó de la cruceta aragonesa, quedándose sólo con la insignia castellana, cuando Pedro IV le prohibió la simultánea ostentación de $\operatorname{ambas}^{32}$.

${ }^{27}$ Froissart sitúa erróneamente esta coronación en "Astourges" (¿Asturias?), antes de pasar a Burgos. La presencia de laicos junto a los personajes eclesiásticos en este tipo de representaciones de coronación empieza a documentarse en la miniatura francesa hacia 1315-1320; Marta SERRANo ColL, El códice AGN B-2 y la iconografía de coronaciones y exequias regias en el arte bajomedieval, en Ceremonial de la coronación, unción y exequias de los reyes de Inglaterra, Pamplona, 2008, p. 165.

${ }^{28}$ Lopes, Chronica de El-Rei D. Pedro I, ob. cit., p. 343; López de Ayala, Crónica de Pedro I, año 1366, cap. 3, p. 538; cap. VII, p. 541.

${ }^{29}$ Según Salazar y Acha, el cargo nace con Alfonso XI, pero no se documenta su primer titular hasta 1367 en la persona de Pedro López de Ayala -señor de Campos, Albudeite y Levadura- que lo cede a su homónimo Pedro López de Ayala (1332-1407), el cronista y canciller mayor, señor de Ayala y Salvatierra. Éste ocupó el cargo al menos entre 1371 y 1385, y probablemente hasta su sustitución por su primogénito Fernán López de Ayala en 1404, que lo cedería a su vez en 1431 a su heredero Pedro López de Ayala el sordo, I conde de Fuensalida, que lo mantuvo hasta 1444; cfr. Jaime de SALAZAR Y ACHA, La Casa del Rey de Castilla y León en la Edad Media, Madrid, 2000, pp. 212-213 y 444-446.

${ }^{30}$ Sobre su gallarda intervención en la batalla de Nájera cfr. Fernando CASTILLO CÁCERES, Análisis de una batalla: Nájera (1367), en ID., Estudios sobre cultura, guerra y política en la Corona de Castilla (siglos XIV-XVII), Madrid, 2007, pp. 63-68.

${ }^{31}$ José María RocA, Johan I d'Aragó, Barcelona, 1929, p. 169.

${ }^{32}$ La reacción de Martínez de Luna ante la prohibición regia adquiere en la crónica de Juan II el tono de un auténtico desafío: "Yo amas devisas he tenido ante el Rey de Castilla, é nunca me calumnió lo que vos. Señor, agora me calumniades de tener su devisa é la vuestra en uno, é por ende, pues á él todavia plugo que yo trújese la suya, no la dejaré en ninguna guisa, é si á vos, Señor, non place que traya la vuestra por la manera que la traía, tomadla enhorabuena. E quitóla luego de su ropa delante de él, é quedó con sola la devisa de la banda del Rey de Castilla". No debe extrañar que el relato se inserte en los primeros años del reinado de Juan II en que la Banda era enarbolada por el partido de Álvaro de Luna -hijo del protagonista de la historia- contra los infantes de Aragón; Alvar GARCíA DE Santamaría, Crónica de Juan II de Castilla, en Colección de documentos inéditos para la Historia de España [CODOIN], vol. 100, Madrid, 1891, (reed. 1966), año 1431, cap. XXIV, pp. 305-306. 
Clausurado el conflicto sucesorio, el primer Trastámara retomó la representación heráldica de la Banda haciéndola grabar en la Capilla Real de Córdoba, concluida en 1371 para albergar los restos de Alfonso XI y Fernando IV ${ }^{33}$. También levantó las prescripciones alfonsíes que prohibían a los caballeros los adornos dorados, concediendo el derecho de portar "paños de oro y adornos de oro o dorados en las vestiduras, en las divisas y en las bandas" ${ }^{34}$. Con ocasión de las fiestas navideñas trascurridas en Sevilla en 1374, Enrique promocionó la actividad prioritaria de los miembros de la orden, los torneos, "en que lucieron mucho los caballeros de la Vanda, que aunque habia decaido algo de su instituto, queria fomentarla por obra del Rey don Alfonso, su padre" 35 . Se trataba de asegurar la preparación militar de la segunda generación de la orden, considerada bisagra entre los períodos de restricción y expansión del ideal caballeresco en Castilla $^{36}$.

La orden debió adaptarse a las nuevas necesidades militares a raíz de la campaña de Granada que se proyectó en 1375. Según la crónica de Jehan Cabaret d'Oronville, sabemos que Enrique II envió a un "honorable heraldo" llamado "Moniquot" a Louis II de Bourbon "con las más honrosas cartas que pueden verse" solicitando su auxilio militar $^{37}$. El Trastámara recordó entonces los lazos existentes entre ambas familias desde que Jean, conde de la Marche, nieto de Louis I, duque de Bourbon, le auxiliara en la guerra contra Pedro I. Ahora solicitaba sus doscientos o trescientos caballeros y escuderos apelando a "vuestra gran fama de buen caballero, discreto y prudente, que ha llegado a mis oídos". La alianza debió confirmarse con un intercambio de divisas pues el duque de Bourbon -el príncipe más emblematizado de su tiempo- accedió gustosamente a participar en esta "empresa honrosa" entregando al heraldo del rey "un escudo con sus armas, ricas vestimentas de paños de oro, y su divisa", probablemente el cinturón verde con la palabra Esperance, insignia de su orden fundada en $1366^{38}$.

Tiempo después, la entente se cerró en el ambiente festivo de la corte instalada en Burgos, donde Enrique II entregó "un caballo árabe y su orden de la banda" a

${ }^{33}$ Estos escudos no reconocibles hoy, debían existir a mediados del siglo XVII cuando Andrés de Morales se refirió a "la divisa de la banda con dos cabezas de dragos, insignia propia del rey [Alfonso XI] como se ve en la capilla real" de Córdoba; Andrés de Morales, Historia General de Córdoba, vol. I, Córdoba, 2005, lib. VI, cap. 19, p. 575; este dato corrige a Pavón Maldonado, Escudos y reyes, ob. cit., p. 186.

${ }^{34}$ Las Cortes de Burgos (1379) ratifican las leyes suntuarias de Enrique II y se incluirán después en el ordenamiento de Montalvo; María José María E IzQuierdo, Las fuentes del ordenamiento de Montalvo, vol. II, Madrid, 2004, p. 6; ver también Nelly Raquel PorRo GIRARDI, La investidura de armas en Castilla: del Rey Sabio a los Católicos, Valladolid, 1998, p. 193.

${ }^{35}$ Diego Ortiz de ZúÑIgA, Anales eclesiásticos y seculares de la muy noble y muy leal ciudad de Sevilla, vol. II, Madrid, 1795, p. 202.

${ }^{36}$ Rodríguez Velasco, El debate sobre la caballería, ob. cit., pp. 13 y ss.

${ }^{37}$ Se trata de la crónica redactada por Jean d'Oronville en 1429 a petición de Jean I, hijo de Louis II de Bourbon; Jehan Cabaret D'Oronville, Chronique du bon duc Loys de Bourbon, ed. A. M. Chazaud, París, 1876, p. 11; usamos la traducción castellana de Raquel Homet; ID., Crónica del buen duque Luis de Bourbon, ed. de Raquel Hornet., Buenos Aires, 1991, caps. XXXVI-XXXVII, pp. 78-80. Véase también el análisis y la documentación aportada por André LeGUAI, Le bourbonnais pendant la guerre de cent ans: de la seigneurie a l'État, Mouliens, 1969, pp. 272-275.

${ }^{38}$ Cfr. Laurent HАвLот, La ceinture Esperance et les devises des Bourbon, en Espérance. Le mécénat religieux des ducs de Bourbon à la fin du Moyen Age (F. Perrot, ed.), Souvigny, 2001, pp. 91-103. 


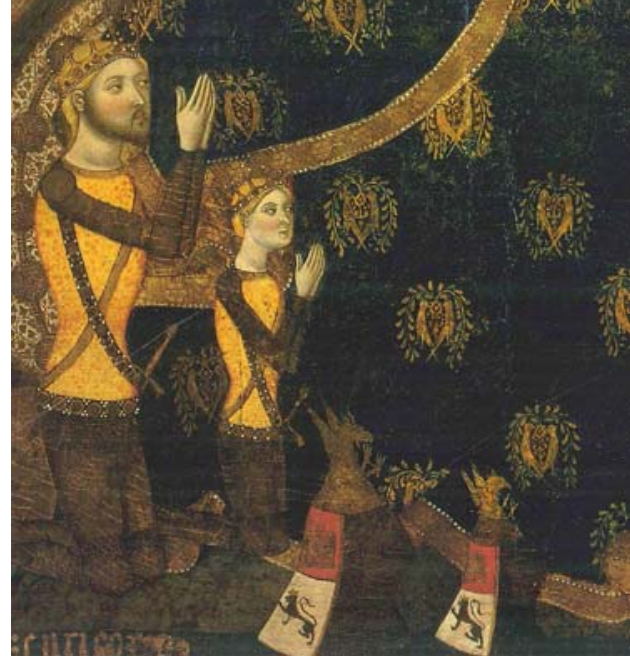

Fig. 3: Enrique II y su primogénito Juan [I] arrodillados con la banda cruzándoles el pecho, junto a sus respectivos yelmos con la cimera del grifo; atribuido a Jaime Serra, Virgen de la leche (c. 1356-1370). Procedente de la Iglesia de Tobed (Zaragoza). Museo Nacional del Prado. Madrid.

siete caballeros mesnaderos (bannerets) que acompañaban al duque ${ }^{39}$. El compromiso asumido no sería, sin embargo, la participación en la campaña granadina frustrada por la reanudación de las hostilidades con Portugal, sino la promesa de ayudar al rey castellano "si él se lo requería por alguna necesidad”; lo que sucedió en 1379 en que el duque de Bourbon acudió en su auxilio ante la invasión del duque de Lancaster ${ }^{40}$. Se ponía de manifiesto así la fuerza de la entente emblemática y la difusión de la Banda gracias a estas nuevas prácticas llamadas a tener gran éxito en décadas posteriores $^{41}$.

La Banda pronto se convirtió en distintivo de la nueva dinastía. Enrique II se hizo representar con ella, junto a su primogénito, en su retrato del retablo de Tobed (c. 1368-1375) (Fig. 3) y en su sepulcro de la catedral de Toledo (13901406) (Fig. 4) ${ }^{42}$. A diferencia de otras divisas que desaparecían con la muerte de su titular, la Banda afianzó su carácter hereditario identificando al rey castellano en el concierto de las monarquías europeas. A mediados del siglo XV se consideraba que "el rey de Castilla [trae] la vanda [como] el rey de Françia truxo vn tiempo la flor de genesta ${ }^{43}$ y el rey de Ynglaterra

${ }^{39}$ El magnífico recibimiento y las fiestas cortesanas que el rey de Castilla ofreció al duque en Burgos y en Segovia se recogen en OronviLle, Crónica del buen duque, ob. cit., cap. XXXVII, pp. 7980; y de manera más sucinta en Pedro LóPez de Ayala, Crónica de Enrique II, en Crónicas de los reyes de Castilla, ed. Cayetano Rosell, Biblioteca de Autores Españoles, vol. 68, Madrid, 1898, año 1376, cap. I, p. 29, donde se alude a la "grand fiesta" y las "muchas joyas" con que Enrique II le agasajó, sin mencionar la entrega de las insignias.

${ }^{40}$ El duque colaboró activamente en el levantamiento del asedio sobre Burgos y persiguió a las tropas inglesas hasta Portugal, según el testimonio de Oronville, Crónica del buen duque, ob. cit., caps. LXI-LXIII, pp. 112-115.

${ }^{41}$ La difusión de esta práctica ha sido estudiada por Laurent HАвLOт, Les signes de l'entente. Le rôle des devises et des ordres dans les relations diplomatiques entre les ducs de Bourgogne et les princes étrangers de 1380 à 1477, "Revue du Nord", 345-346 (2002), pp. 319-341.

${ }^{42}$ Así ha sido identificada la banda bordada con flores de oro que cruza su túnica; cfr. Vicente Carderera y Solano, Iconografía española. Colección de retratos, estatuas mausoleos y demás monumentos. vol. I, Madrid, 1855, lámina XXX; Ricardo del Arco, Sepulcros de la casa real Castilla, Madrid, 1954, pp. 316-317; véanse también las precisiones de María Teresa Pérez Higuera, Los sepulcros de los Reyes Nuevos (Catedral de Toledo), "Tekne”, 1 (1985), pp. 132-133; Menéndez Pidal, Heráldica de la casa real, ob. cit., p. 263.

${ }^{43}$ Se trata de la divisa de la vaina de retama (cosse de genêt) que usaba Carlos VI (1380-1422) como una de sus preferidas al menos desde 1387, y asumió la forma de orden caballeresca antes de que Carlos VII (1429-1461) la abandonara al difundirse entre sus parientes y rivales ingleses; Laurent HABLOT, 
el çiervo bolante" 44 . Su prestigio y su flexibilidad como monarchical nonconfraternal knithgly order, la convirtió en un instrumento político útil para garantizar fidelidades y afirmar la imagen caballeresca de los Trastámara ${ }^{45}$.

\subsection{EL NUEVO ORDEN DE JUAN I: TRASFORMACIONES CEREMONIALES}

Juan I (1379-1390) se sintió muy ligado a la política caballeresca de Alfonso XI y Enrique II. Su acceso al trono en 1379 repite la secuencia ritual protagonizada por su padre (proclamación-coronación), con su alzamiento en Santo Domingo de la Calzada (29.V.1379), y su coronación en Burgos (25.VIII.1379) $)^{46}$. No obstante, el ritual seguido introducía algunas "novedades" que reflejan su voluntad de acomodar su autoridad a las nuevas circunstancias, conteniendo a la nobleza y dando entrada a los grupos urbanos en la participación política.

A diferencia de Enrique II, coronado el día de la Resurrección, su hijo escogió la festividad de Santiago (25 de julio), celebrando el acto tras su propia investidura caballeresca ${ }^{47}$. Luis Suárez

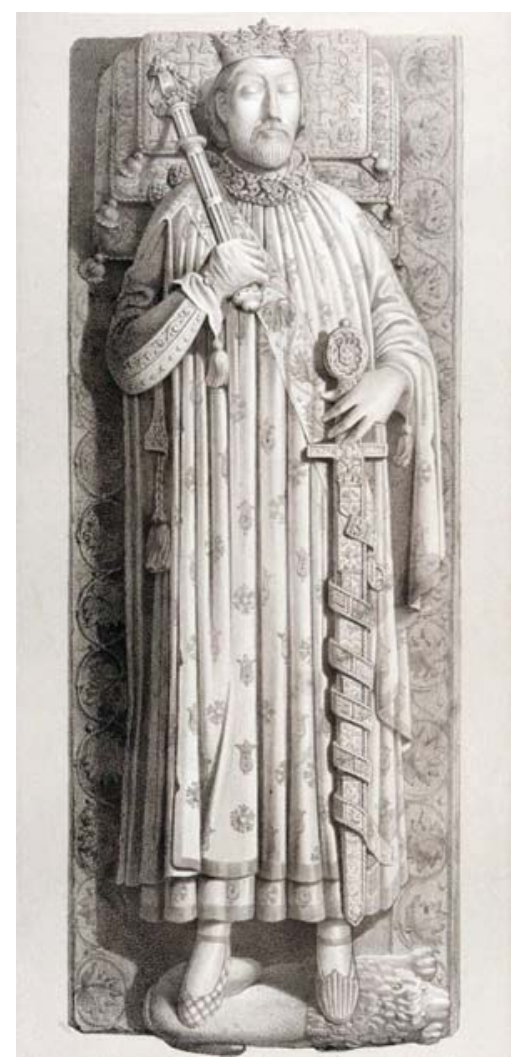

Fig. 4: Sepulcro de Enrique II en la catedral de Toledo (1390-1406), con cetro, espada y una banda cruzándole el pecho. Capilla de los Reyes Nuevos de la Catedral de Toledo. Dibujo: Vicente Carderera y Solano.

L'ordre de la Cosse de genêt de Charles VI: mise en scène d'une devise royale, "Revue française d'héraldique et de sigillographie", 69-70 (1999-2000), pp. 131-148.

${ }^{44}$ Probablemente se refiere al ciervo blanco -recostado y encadenado- que usó como divisa Eduardo III de Inglaterra y, sobre todo, Ricardo II (1377-1399), y que se distingue del ciervo alado (cerf volant) adoptado por Carlos VI de Francia en 1382; BeAUNE, Costumes et pouvoir, ob. cit., pp. 130-131; HaBLOT, La devise, mise en signe du prince, ob. cit., pp. 559-572. El texto entrecomillado procede de los Vocablos castellanos (siglo XV); Real Academia de la Historia (Madrid), Colección Salazar y Castro, manuscrito 73 (12-7-2), en Nuevo Tesoro Lexicográfico del español (S. XIV-1726), ed. L. Nieto Jiménez y M. Alvar Ezquerra, vol. IV, Madrid, 2007, p. 3823. La designación de "dinastía de la Banda" -sin particulares precisiones emblemáticas- ha sido empleada por Ana Echevarría Arsuaga, La dinastía de la Banda: de Alfonso XI a los Trastámaras, en Ibn Jaldun: el Mediterráneo en el siglo XIV: auge y declive de los imperios (M. J. Viguera Molíns, coord.), Granada-Sevilla, 2006, pp. 68-73.

${ }^{45}$ Boulton, The knights of the crown, ob. cit., p. 543.

${ }^{46}$ López de Ayala, Crónica de Juan I, año I, cap. I, p. 65; Fernão Lopes, Chronica de El-Rey D. Fernando, nono rei destes regnos, vol. II, Lisboa, 1885, pp. 183-184.

${ }^{47}$ Hinojosa, Continuación de la crónica de España, ob. cit., p. 101. 
Fernández, Peter Linehan y José Manuel Nieto Soria consideran la posibilidad de que Juan I fuera investido en las Huelgas mediante la escultura articulada del apóstol Santiago que se conservaba allí, como había hecho su abuelo en $1332^{48}$. De esta forma, no sólo recibía esta dignidad del mismo patrón de la caballería sin quedar supeditado a mortal alguno, sino que conectaba con la tradición ceremonial inaugurada por la principal referencia legitimadora de su dinastía, la representada por Alfonso $\mathrm{XI}^{49}$. Tales precauciones se justifican en aquel momento de desconcierto en que Juan de Gante pensaba que Juan I ya había sido coronado por su padre, y Fernando I de Portugal rechazaba su invitación a la ceremonia por tratarse del hijo de un bastardo que había asesinado a su hermano ${ }^{50}$. De ahí el interés del Trastámara por dar publicidad a aquellos actos convocando a príncipes de otros reinos, y caballeros y representantes de las ciudades que debían participar en la investidura masiva y la reunión de Cortes convocadas para entonces ${ }^{51}$.

Gracias al testimonio de un heraldo de Carlos II de Navarra, podemos reconstruir la ceremonia de 1379 con más precisión que López de Ayala ${ }^{52}$. Según la fuente navarra trascrita por Froissart, Juan I no fue coronado en el monasterio de las Huelgas, como afirma el cronista castellano, sino en la catedral de Burgos, tal vez para contar con un

${ }^{48}$ LineHAn, Historia e historiadores, ob. cit., pp. 619-621; José Manuel NiETo SoRIA, Ceremonias de la realeza: propaganda y legitimación en la Castilla Trastámara, Madrid, 1993, p. 75.

49 Tres años después, el 6 de julio de 1382, Juan I imitó nuevamente a su abuelo al solemnizar la investidura del oficio de condestable, sustituyendo los ritos de comensalidad que empleara Alfonso XI por los usos feudovasalláticos de las Partidas del rey Sabio. El ritual empleado por Juan I para la investidura de Alonso de Aragón como primer condestable, celebrada en el Real de Ciudad Rodrigo el 6 de julio de 1382, se recoge en SalazAr DE Mendoza, El origen de las dignidades seglares, ob. cit., pp. 319-320. Sobre la ceremonia de Alfonso XI véase el sugerente análisis de Francisco BAUTISTA, "Comed conde": Las transformaciones de un ritual del Cantar de Mio Cid a Diego de Valera, en Nelly LABÈre (coord.), Etre à table au Moyen Âge, Madrid, 2010, pp. 65-75. La descripción de la investidura del almirante se recoge en Partidas, II, 3, 24, y ha sido estudiada por Alfonso de Ceballos-Escalera Gila, Norma y ceremonia de los Almirantes de Castilla, Madrid, 2007, pp. 39-89.

${ }^{50}$ Usamos el texto de las Chroniques de Jean Froissart contenido en Chicago, Newberry Library, MS Case f. 37 (vol. 2), f. 50r; véase el sitio web: http://www.hrionline.ac.uk/onlinefroissart/index.jsp.

${ }^{51}$ Un índice de la importancia de la ceremonia son los gastos del lujoso vestuario regio que se ha relacionado con los actos de 1379; cfr. María Martínez Martínez, La imagen del rey a través de la indumentaria: el ejemplo de Juan I de Castilla, "Bulletin Hispanique", 96-2 (1994), pp. 277-287; y las cuentas del mayordomo del concejo conservadas en el Archivo Municipal de Burgos y comentadas por Anselmo Salvé, Cosas de la vieja Burgos, Burgos, 1892, pp. 144-148.

${ }^{52} \mathrm{Se}$ trata de un heraldo que había acompañado al rey de Navarra en las conversaciones de paz con Enrique II y que, tras el fallecimiento de éste, permaneció en Castilla por orden de su señor asistiendo a la coronación de su heredero en Burgos. Reproducimos la parte de la respuesta relativa a estos acontecimientos que el heraldo dirigió al duque de Lancaster cuando fue interrogado al respecto, tal y como la reproduce Jean Froissart: "Et trespassa chils rois Henris le jour de le Penthecouste. Assés tos apriés, le XXVe jour dou mois de jullet, le jour saint Jakeme et saint Cristofle, fu couronnés a roi dan Jehans de Castille, aisnés fils dou roi Henri, en l'eglise cathedral de la chi tet de Burghes, auquel couronnement furent tout li prelat et li noble de Castille, d'Espagne, de Galisce et de Corduan et de Sebille. Et tout li jurerent seür Saintes Evangilles a tenir roi. Et fist che jour CC et X chevaliers. Et donna moult de biaus dons. A l'endemain de son couronnement a grant compagniie il s'en vint en une abbeye de dames au dehors de Burghes, que on dist le Sorghes. La oÿ la messe et disna. Et la eut grans joustes et en oeut le pris li viscontes de Rokebertin d'Aragonne. Et che viespre retourna li rois a Burghes et durerent ses fiestes bien XVe jours"; Chicago, Newberry Library, MS Case f. 37 (vol. 2), f. 50r; o en la edición clásica de Froissart, Chroniques, ob. cit, vol. IX, pp. 121-123. 
espacio sagrado más amplio y público que diera cabida a "tout li prelat et li noble de Castille, d'Espagne, de Galisce et de Corduan et de Sebille". Con evidente intención exaltadora, el cronista enfatiza la unánime participación de la aristocracia laica y eclesiástica, mostrando la adhesión de las élites al nuevo monarca con su juramento sobre los Santos Evangelios.

No parece que Juan I recurriera a la autocoronación practicada por su abuelo, como postula Schramm ${ }^{53}$. Más bien, quiso enfatizar la recepción de la dignidad regia a través de mediadores apostólicos (Santiago) ${ }^{54}$ y la memoria de sus antepasados (Alfonso XI) en un ritual de intensas resonancias religiosas y caballerescas que culminó con la investidura de "cien caballeros de su Regno de linaje de Ricos omes, Caballeros", según Ayala ${ }^{55}$, o 210 caballeros según el heraldo navarro. Esta práctica que recuperaba el modelo celebrativo de Alfonso XI, pretendía probablemente recomponer la autoridad del segundo Trastámara con la nueva generación de nobles que, además de recibir la investidura, obtuvieron sustanciosas dádivas reales y tal vez la orden de la Banda ${ }^{56}$.

Un último aspecto significativo fue el papel asignado a la reina, su esposa Leonor de Aragón, hija de Pedro IV el Ceremonioso, a quien el rey "fizo coronar" 57 . Un gesto que no se documenta en el caso de Juana Manuel, esposa de Enrique II, y que

${ }^{53}$ La crónica atribuida a Gonzalo de Hinojosa señala que "se coronó él e la reyna doña Leonor, su mujer"; Hinojosa, Continuación de la crónica de España, ob. cit., p. 101; López de Ayala dice que "en aquel dia que él se coronó, fizo coronar a la Reyna Doña Leonor su muger, que era fija del Rey Don Pedro de Aragon"; LóPez DE AYAla, Crónica de Juan I, año I, cap. I, p. 65. Si la primera fuente permite conjeturar el mismo rito para ambos esposos, y la segunda afirma explícitamente que la reina no fue coronada por el rey, cabe deducir que ambos debieron ser coronados por los obispos, como era usual en la tradición castellana. Froissart mantiene el mismo esquema discursivo de la coronación de Enrique II, atribuyendo a su hijo un papel pasivo en la ceremonia que fue protagonizada por la comunidad: "En cel an trespassa li rois dans Henris de Castille, dont tous ses roiaumes fu durement couroucie. Tantost aprés son trespas li Espaignol et li Castellain couronnerent a roi son aisnet fil dant Jehan"; véase el sitio web: http://www.hrionline.ac.uk/onlinefroissart/index.jsp; o la citada edición clásica de FroISSART, Chroniques, ob. cit, vol. IX, p. 155. La opinión de Schramm en Percy Ernst Schramm, Las insignias de la realeza en la Edad Media española, Madrid, 1960, p. 68.

${ }^{54}$ La devoción de Juan I por el patrono de la caballería se refleja en detalles como la introducción de la cruz de Santiago en la sigilografía regia, las invocaciones al apóstol antes de la batalla de Aljubarrota o su apelación ante las tropas del duque de Lancaster en 1386; cfr. César Olivera Serrano, Los Trastámara y el Apóstol Santiago, Iacobus: revista de estudios jacobeos y medievales, "Iacobus: revista de estudios jacobeos y medievales", 25-26 (2009), pp. 271-272.

${ }^{55}$ Sobre estas investiduras masivas cfr. Porro GIRARDI, La investidura de armas en Castilla, ob. cit., pp. 100 y ss.

${ }^{56}$ La relación de la investidura caballeresca con los rituales de coronación de los reyes ha sido puesta de manifiesto por KeEN, La caballería, ob. cit., pp. 101 y ss. La entrega de la Banda con motivo de la investidura se conjetura en las ordenaciones caballerescas efectuadas por Alfonso XI -paradigma de las de su nieto- con motivo de su coronación, celebrada en fechas muy cercanas a la creación de la insignia de la Banda; cfr. García Díaz, La orden de la Banda, ob. cit., pp. 49 y 55.

${ }^{57} \mathrm{La}$ expresión podría ponerse en relación con el gesto de Sancho IV en la ceremonia de su coronación (1284), donde "fizo tomar por reina a doña María, su mujer, e fizo tomar por heredera a la infanta doña Isabel, su fija, si fijo varón no oviese", lo que permite advertir algún tipo de juramento prestado a ambas mujeres, como debió suceder en el caso de Leonor de Aragón en 1379 y se documenta en el caso de Beatriz de Portugal en 1383; José Manuel NieTo Soria, La coronación del rey: los símbolos de su poder, en Alfonso Xy su época. El siglo del Rey Sabio, Barcelona, 2001, pp. 149-151. 
se aparta del ritual de subordinación política practicado por Alfonso XI en 1332 al coronar él mismo a su esposa ${ }^{58}$. Con su modo de proceder Juan I reconocía a su consorte una dignidad autónoma y unas insignias equivalentes a las suyas, como el espléndido "paño de oro" que las autoridades burgalesas le entregaron en $1379^{59}$. De esta forma el monarca consolidaba sus propios derechos al trono como vástago de Juana Manuel, como cuatro años después hará al reclamar la Corona portuguesa por su matrimonio con Beatriz, heredera de Fernando I de Portugal ${ }^{60}$.

Al día siguiente, los reyes se trasladaron con gran acompañamiento ("a grant compagniie") al monasterio de las Huelgas, para celebrar la Misa y ofrecer un solemne banquete. La Eucaristía se separa de esta forma del acto de la coronación, distinguiendo la faceta más política de la ceremonia, de la sacramental. Del ágape eucarístico se pasó el banquete regio en un gesto de magnanimidad y convivialidad aristocrática que exigió del Concejo "todas las mas calderas y tajadores y escudiellas que pudieran haber" ${ }^{61}$. Por la tarde la nobleza invitada participó en las grandes justas ("grans joustes") celebradas en las proximidades del monasterio en forma de competición deportiva que ganó Felipe Dalmau, miembro de la alta nobleza catalana y I vizconde de Rocaberti († 1392). El dato es elocuente de la dimensión ibérica que Juan I quiso dar a la ceremonia con la presencia de caballeros de la Corona de Aragón o de aquellos ocho trompeteros y charamberos enviados por el rey de Navarra ${ }^{62}$.

Tras la celebración aristocrática se dio paso a la alegría urbana. Al anochecer, Juan I y Leonor de Aragón regresaron a la ciudad para abrir "muy grandes fiestas" que duraron quince días. El Concejo burgalés no sólo se jugaba su prestigio, sino importantes dádivas como la concesión de la villa de Pancorbo que dispuso el rey imitando el ejemplo de su abuelo al entregar la villa de Muñó en recuerdo de su coronación (27.X.1332) ${ }^{63}$. La caballería urbana proporcionó 50 bofordadores que debían pertenecer a la cofradía de Santiago de Burgos, asociada al impulso fundador

58 Juana Manuel fue recibida "honradamente" en Burgos después de que su marido abandonara la ciudad camino de Toledo, no antes del 25 de junio. Procedía de tierras aragonesas, de donde se desplazó con sus hijos Juan y Leonor; LoPes, Chronica de El-Rei D. Pedro I, ob. cit., p. 344; y el comentario de VALdeÓn BARUQue, Pedro I, el Cruel, ob. cit., pp. 143-144.

${ }^{59}$ Los 860 maravedíes del paño de la reina superaban ampliamente los 100 maravedíes que costaron los tablados, carros y castillos que realizaron los artífices moros, y los 150 que costó cada uno de los toros que se corrieron en los festejos de la coronación; SALvÁ, Cosas de la vieja Burgos, ob. cit., p. 145; sobre la importancia de esta insignia cfr. Álvaro Fernández de Córdova Miralles, Los símbolos del poder real, en Los Reyes Católicos y Granada (Bartolomé, A., y Hernando Sánchez, C. J. ed.), Granada, 2005, pp. 45-48; Alfonso de Ceballos-Escalera Gila, y Carlos Navarro, Los mantos en la heráldica española, "Cuadernos de Ayala", 20 (2004), pp. 9-21.

${ }^{60}$ Sobre la importancia de las reinas en la sucesión de los Trastámara cfr. Jean-Pierre JARDIN, Le rôle politique des femmes dans la dynastie Trastamare, e-Spania [En línea], 1 | juin 2006, puesto en línea el 17 julio 2010, consultado el 30 mai 2013. URL: http://e-spania.revues.org/322; DOI : 10.4000/e-spania.322; y el trabajo de César Olivera Serrano, Beatriz de Portugal. La pugna dinástica Avis-Trastámara, Santiago de Compostela, 2005.

${ }^{61}$ Las fuentes concejiles especifican que al final se recogieron 20 calderas, 2000 tajadores y 2000 escudiellas; SAlvé, Cosas de la vieja Burgos, ob. cit., p. 146.

${ }^{62}$ Salvá, Cosas de la vieja Burgos, ob. cit., p. 144.

${ }_{63}$ Julián García SÁrnz de Baranda, La ciudad de Burgos y su Concejo en la Edad Media, Burgos, 1967, p. 58. 
de Alfonso XI (c. 1338) ${ }^{64}$, y experimentados en la antigua práctica de los bohordos. Los caballeros fueron uniformados con paños, mantos y tabardos para encubertar sus monturas, que debían portar ocho docenas de cascabeles y venir acompañados con dos mulas y mozos para mayor lucimiento. El Concejo costeó además la corrida de 16 toros, los tablados levantados en las plazas de Sarmental y la Comparada para los espectáculos ecuestres, y 8 carros realizados por artífices moros y lujosamente adornados, uno de los cuales portaba dos castillos de madera en que iban juglares y trompeteros divirtiendo a la gente ${ }^{65}$.

Soberano del gaudium urbano, el rey se sitúa en el centro de la fiesta en busca de la legitimidad de las antiguas tradiciones que custodian las hermandades caballerescas y debían difundirse más allá del espacio burgalés. Así lo prueban las ordenanzas murcianas que prescribían la orden real de celebrar bohordos, juegos de cañas y lanzamientos de tablado, exigiendo la participación de todos los juglares, trompeteros, tableros y gaiteros de la ciudad ${ }^{66}$. Mientras tanto en Burgos los festejos urbanos darían paso a la celebración de las Cortes convocadas el 1 de agosto para prestar homenaje al monarca.

A la luz de estas consideraciones, el ceremonial desarrollado por Juan I muestra un deslizamiento de los fundamentos legitimadores hacia valores caballerescos que otorgan mayor protagonismo al rey en un escenario donde la nobleza y las clases urbanas aparecen como sostenedores del régimen. En este sentido cabe interpretar las "ceremonias de cooperación" introducidas por el segundo Trastámara para realzar su coronación: la masiva investidura caballeresca y la reunión de las $\operatorname{Cortes}^{67}$. Ambos actos pretendían integrar a las élites en el nuevo régimen estructurado según el modelo organicista con el rey como cabeza de un cuerpo que es el reino ${ }^{68}$, y el Bien Común como principio jurídico esencial para unir a los miembros de la sociedad política $^{69}$. Gimeno Casalduero ha señalado las consecuencias eclesiológicas de este plateamiento, rastreándolas en el conciliarismo defendido por los consejeros de Juan I como solución para resolver el Cisma que dividía a la Iglesia, pues si el concilio representa a todos debe resolver lo que a todos atañe, como afirmaba el

64 SAlvá, Cosas de la vieja Burgos, ob. cit., pp. 143-145. Sobre la cofradía cfr. Faustino MENÉNDEZ Pidal de Navascués (ed.), Caballería medieval burgalesa. El libro de la cofradía de Santiago, Burgos, 1996; y las observaciones de Rodríguez Velasco, Ciudadanía, soberanía monárquica, ob. cit., pp. 103109.

65 Salvá, Cosas de la vieja Burgos, ob. cit., pp. 144-146.

66 SuÁrez Fernández, Historia del reinado de Juan I, ob. cit., vol. I, p. 27; Nieto Soria, Ceremonias de la realeza, ob. cit., p. 28.

67 Sobre las "ceremonias de cooperación" cfr. Nieto Soria, Ceremonias de la realeza, ob. cit., pp. 69-71; NiEto Soria, Ceremonia y pompa para una monarquía: los Trastámara de Castilla, "Cuadernos del CEMYR", 17 (2009), pp. 61-64.

${ }^{68}$ Como se expondrá en las Cortes de Briviesca de 1387; cfr. José Manuel NiEto SoriA, La Realeza, en Orígenes de la monarquía hispánica: propaganda y legitimación (ca. 1400-1520) (J. M. NIETO SORIA, coord.), Madrid, 1999, pp. 214-215.

${ }^{69}$ Sobre el impulso de este principio jurídico-político durante el reinado de Juan I cfr. José Manuel Nieto Soria, Los fundamentos ideológicos del poder real en Castilla (siglos XIII-XVI), Madrid, 1988, pp. 148-190. 
arzobispo de Toledo, Pedro Tenorio (c. 1328-1399)70. No sería extraño que este prelado especialmente activo en la coronación de Burgos fuera uno de los principales ideólogos de la ceremonia y del pensamiento político del rey en aquellos primeros años de su reinado ${ }^{71}$.

\subsection{LA BANDA DE JUAN I DE CASTILLA: MUTACIONES CABALLERESCAS}

El nuevo orden de Juan I exigió algunos reajustes del modelo caballeresco de la Banda heredado de su padre. Ante el uso que los descendientes de Pedro I hacían de su insignia, el segundo Trastámara intensificó su vinculación a la orden con medios ceremoniales y representativos, que incluía la realización de posibles nombramientos durante su coronación y la introducción de la insignia en sus representaciones sigilográficas y quizá monetarias. No se trataba sólo de difundir su imago con los oropeles de la caballeria, sino de aumentar el valor representativo de la Banda al quedar incorporada a instrumentos de validación documental. En las improntas sigilográficas de 1382 y 1385 Juan I añadió a su representación mayestática -sentado entre dos leones y sosteniendo espada y globus - una banda que cubría su hombro derecho cayendo por debajo del brazo izquierdo (Fig. 5 y 6), tal y como la portan sus propios caballeros en las representaciones funerarias que más adelante comentaremos ${ }^{72}$. De su cuidadosa decoración dan idea los gastos por "dos onças de seda e quatro varas de lienço de que borlaron las bandas de aljófar" que el rey ordenó en Valladolid hacia 1380 junto a otros arreglos para el sombrero de su corona ${ }^{73}$. La presencia de perlas pequeñas e irregulares (aljófar) o los adornos florales que se observan en las bandas de algunos sepulcros, reflejan el imparable crecimiento del lujo a despecho de los

${ }^{70}$ Cfr. Gimeno Casalduero, La imagen del monarca en la Castilla del siglo XIV, ob. cit., pp. 198199. Sobre este importante eclesiástico cfr. Rafael Sánchez Sesa, Don Pedro Tenorio (c. 1328-1399). Aproximación a la vinculación eclesiástica, familiar y política de un arzobispo toledano al reino de Portugal, "Revista da Faculdade de Letras. História", Serie 2, 15 (1998), pp. 1479-1492. Sobre el Cisma desde el punto de vista castellano SuÁrez Fernández, La crisis de 1383: el punto de vista castellano, "Revista da Facultade de Letras-Historia", Série III (1986), pp. 59-68; Rafael SÁnchez SESA, El Cisma de Occidente en la Península Ibérica: religión y propaganda en la guerra castellano-portuguesa, en Estudos em homenagem ao professor doutor José Marques, vol. IV, Oporto, 2006, pp. 307-320.

${ }^{71}$ La presencia del arzobispo con su gran séquito no pasó desapercibida aquellos días, en que tuvo un conflicto con el cabildo de Burgos al ordenar alzar su cruz como metropolitano; SUÁREZ FERNÁNDEZ, Historia del reinado de Juan I, ob. cit., vol. I, p. 27.

72 Sello de plomo de Juan I (1385); privilegio real a favor de Beatriz Ponce (Madrigal, 15 marzo 1385); dibujo de la impronta en Luis Salazar y Castro, Pruebas de la Historia de la Casa de Lara, Madrid, 1694, pp. 261-262 (donde se indica su procedencia del Archivo de Nájera); y el sello de plomo de Juan I (1382); privilegio real a Alfonso Ruiz de Arnedo, 16 abril 1382 (procedente del Archivo de Medina Sidonia); dibujo de la impronta en Lorenzo Tadeo Villanueva, Memoria sobre la Orden de Caballería de la Banda de Castilla, "Boletín de la Real Academia de la Historia", 72 (1918), p. 452; otro sello de 1392 del Archivo Histórico Nacional (n. 48), "en su pecho una cruz, y cruzada sobre él una banda que flota por efecto de la carrera", se registra en Juan Menéndez PIDAL, Sellos españoles de la Edad Media, Madrid, 1918, p. 50; no se recogen estas improntas, ni se menciona la presencia de la banda en los ejemplares descritos por Araceli Guglieri Navarro, Catálogo de sellos de la sección de sigilografía del Archivo Histórico Nacional, vol. I, Valencia, 1974, pp. 188-201.

${ }^{73}$ Villalobos y Martínez-Pontrémuli, Las gestiones hacendísticas de Diego López de Estúñiga, ob. cit., p. 194; Cañas Gálvez, La Casa de Juan I de Castilla, ob. cit., p. 151. 
Fig. 5: Sello de plomo de Juan I (1385) con una banda cruzándole el pecho; privilegio real a favor de Beatriz Ponce (Madrigal, 15 marzo 1385). Dibujo: Luis de Salazar y Castro.

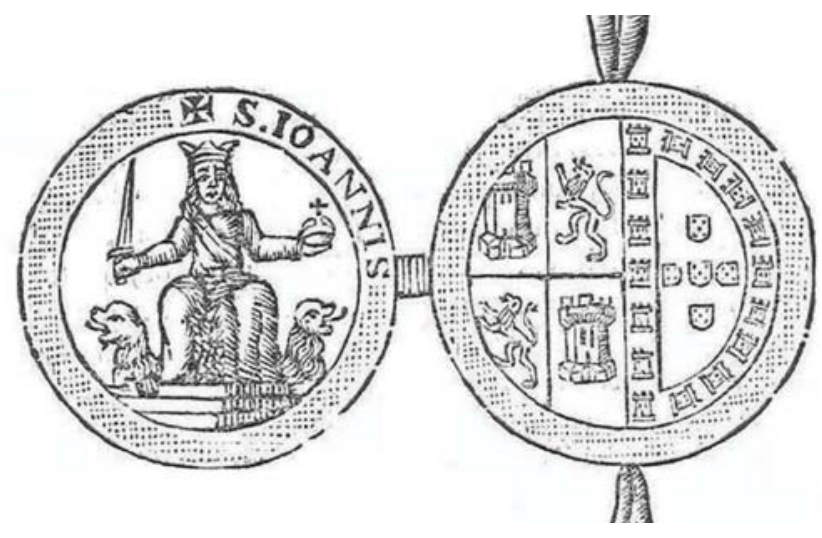

Fig. 6: Sello de plomo de Juan I (1382) con una banda cruzándole el pecho; privilegio real a Alfonso Ruiz de Arnedo, 16 abril 1382; procedente del Archivo de Medina Sidonia. Dibujo: Lorenzo Tadeo Villanueva.

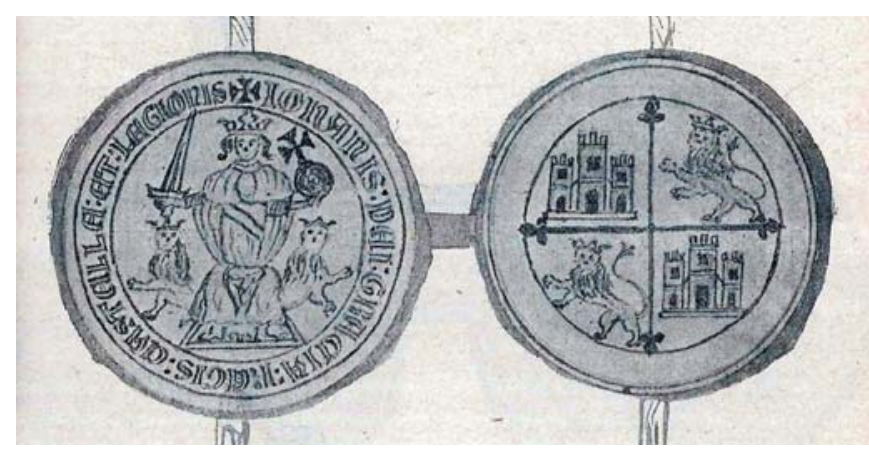

austeros ideales de Alfonso XI. Probablemente era el precio que debía pagar una insignia que de signo caballeresco se había convertido en símbolo de una dinastía.

Juan I no se contentó con exhibir la Banda en su vestuario y sigilografía. Según Bernabé Moreno de Vargas, también realizó acuñaciones monetarias de oro donde figuraba "un escudo con la banda asida de los dragantes", del que carecemos de testimonio gráfico ${ }^{74}$. Aunque Alfonso XI y Enrique II habían empleado la representación heráldica, era la primera vez que ésta se incorporaba al soporte monetario dotado por Juan I de un especial valor propagandístico ${ }^{75}$. La innovación era sintomática. Se estaba pasando de las representaciones coyunturales a una exhibición más sistemática y polifacética que debía intensificar la visibilidad de la orden en soportes asociados a la persona del rey.

${ }^{74}$ Bernabé Moreno de Vargas afirma en sus Discursos de la nobleza de España (1636) que Juan I "ilustró mucho la Caballería de la Banda, y la puso por empresa en su monedas; y yo tengo una que es de oro, y tiene un escudo con la banda asida de los dragantes"; Bernabé Moreno de VARGas, Discursos de la nobleza de España, Madrid, 1795, pp. 159-160.

${ }^{75}$ Así lo manifiesta el uso de las armas partidas de Castilla y Portugal para expresar sus reivindicaciones portuguesas (1383), o las acuñaciones de las "blancas" del Agnus Dei para legitimar sus derechos al trono castellano frente al duque de Lancaster (1386); cfr. Antonio Orol, Acuñación de Juan I de Castilla, como rey de Portugal, "Numisma", 231 (1992), pp. 43-49; y nuestro trabajo FeRNÁNDEZ DE Córdova Miralles, Los emblemas de la conquista, ob. cit., pp. 250-255. 
La nueva política de Juan I debe estar relacionada con la dimensión jurídica que otorgó a los estatutos de la orden al incluir su Segundo Ordenamiento en los cuadernos de Cortes compilados durante el reinado ${ }^{76}$. El reglamento no sólo adquiría de esta forma fuerza de ley, sino que funcionaba como elemento legitimador de la dinastía y fundamento místico de la autoridad legal. La orden adquirió entonces un valor paradigmático que podía inspirar otro tipo de ensayos religioso-caballerescos como la cofradía cacereña de Nuestra Señora del Salor, fundada por el rey en 1383 "a imitación de la de la Banda", manifestando de esta forma el progresivo desplazamiento de la caballería Trastámara hacia modelos devocionales que se intensificarán en el segundo período del reinado ${ }^{77}$. Es posible que algunos eclesiásticos estuvieran detrás de esta transformación religiosa que dotaba a los estatutos de un valor normativo, ético e ideológico, que décadas después ponderó Alonso de Cartagena al insertarlos en su Doctrinal de caballeros (c. 1444). En tiempos de Juan I tal vez fuera el arzobispo de Toledo, Pedro Tenorio, uno de sus principales impulsores, teniendo en cuenta sus lazos familiares con caballeros de la primera generación de la Banda y su acción al frente de una de las diócesis castellanas más ligadas a la memoria de la orden ${ }^{78}$.

La batalla de Aljubarrota de 1385 supuso un serio revés para la agrupación caballeresca. Su enseña cayó junto al pendón real, y su alférez López de Ayala - "cubierto de heridas y quebrantados dientes y muelas"- fue entregado al cautiverio al ser descubierto entre los prisioneros ${ }^{79}$. Los efectivos de la Banda debieron verse tan mermados que en 1387 Juan I premió con su insignia a las mujeres de Palencia por su intervención en la defensa de la ciudad frente al ejército anglo-luso del duque de Lancaster, autorizándolas a portarla en sus tocados y ropas "como las traen los caballeros de la banda, pues ellas suplieron el oficio de ellos" $"$. Con ello se forzaban

${ }^{76}$ Rodríguez Velasco, Ciudadanía, soberanía monárquica, ob. cit., pp. 159-162.

77 Como señala Rodríguez Velasco, la ausencia de datos impide sacar demasiadas conclusiones sobre esta institución; Ibidem, pp. 159-160.

${ }^{78}$ Entre los primeros miembros nombrados por Alfonso XI y recogidos en los estatutos, se halla Garcia Jufre de Tenorio, Juan Tenorio y Alonso Tenorio. Como más adelante veremos, la mayor parte de los sepulcros en los que se aprecia el distintivo de la orden pertenecen a caballeros toledanos y fueron realizados por el taller que Ferrand González mantenía en la ciudad. Algunos detalles de la capilla sepulcral del propio Pedro Tenorio (Capilla de San Blas, en catedral de Toledo) podrían vincularse con la orden, como el ropón y zapatos que viste el arzobispo en su efigie sepulcral -relacionados por Ramírez de Arellano con las vestes de la orden-, o los dragones que decoran la bóveda central de la capilla y podrían relacionarse con los dragantes del escudo de la orden.

${ }^{79}$ Seguramente se trata del pendón de la divisa que cayó junto al pendón de Castilla en la fase final de la batalla; Fernão Lopes, Chronica de El-Rei D. João, vol. IV, Lisboa, 1897-1898, p. 168. Sobre el comportamiento de Ayala cfr. Juan de Contreras y López de Ayala (Marqués de Lozoya), El cronista don Pedro López de Ayala y la historiografia portuguesa, "Boletín de la Real Academia de la Historia", 102 (1933), pp. 120-130; Cecilia Devia, La lucha fratricida en el Cuento de los Reyes (El Victorial) y en las Crónicas del canciller Ayala, "Anuario de estudios medievales", 40-1 (2010), p. 396. Se duda de la rotura de sus dientes y la dureza de su encarcelamiento portugués en Antonio SERRANo DE HARO, El embajador Don Pedro López de Ayala, Madrid 2001, p. 101; Michel Garcia, Biografia de Don Pero López de Ayala: una revisión crítica, en Aiala Kantzilerraren Figura: Aiala Kantzilerraren VI. Mendeurrena (1407-2007) ospatzeko ekitaldiak = La figura del Canciller Ayala, Actos conmemorativos del VI Centenario Canciller Ayala 1407-2007, Vitoria, 2007, pp. 72-77.

${ }^{80} \mathrm{El}$ autor añade que "muchas dueñas nobles, aun asta nuestro tiempo se preciaron de traer aquellas bandas, de que ya no ay memoria"; Alonso Fernández de Madrid, Silva Palentina, Palencia, 1976, pp. 
aún más sus estatutos en la línea aperturista emprendida por Pedro I al admitir a no cristianos y Enrique II a extranjeros. Con ello la antigua orden monárquica de Alfonso XI se acabaría transformando en una pseudo orden clientelar adaptada a las necesidades del rey ${ }^{81}$.

Aunque las órdenes del Espíritu Santo y la Rosa pretendieron renovar en 1390 el patrimonio caballeresco Trastámara, la insignia de la Banda seguía difundiéndose entre la aristocracia como marca de valor y fidelidad al rey. Si con Enrique II, se había abierto la posibilidad de ostentar adornos dorados en las bandas, durante el reinado de Juan I la insignia irrumpe en los enterramientos aristocráticos como marca que sellaba la memoria caballeresca del linaje. Entre éstos destacan los atribuidos al taller toledano de Ferrand González, como el cenotafio de Pedro Suárez III (1385-1390) -alcalde mayor de Toledo

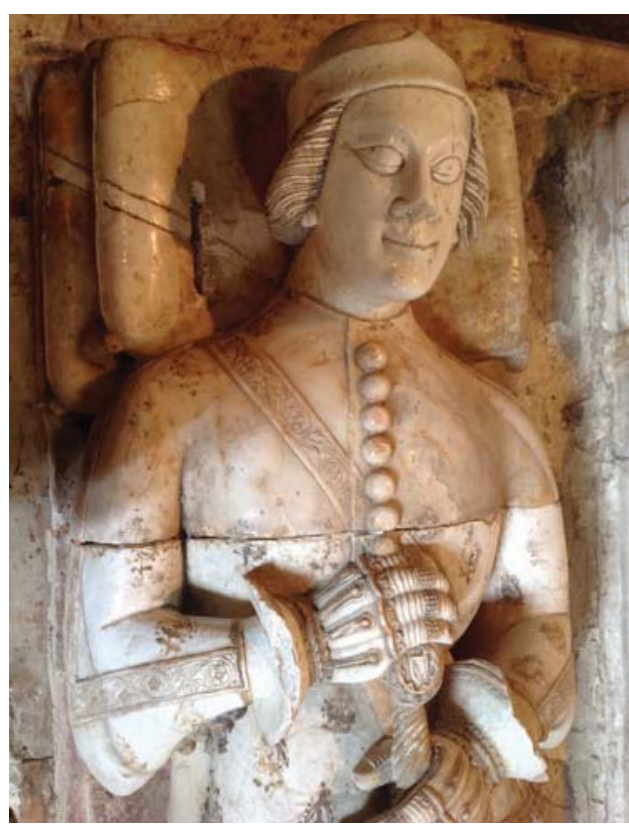

Fig. 7: Sepulcro de Pedro López de Ayala (c. 1390-1400) con la armadura sembrada de picas florecidas, y una banda recorriendo el pecho y las mangas. Monasterio de Quejana. Álava. fallecido en la batalla de Troncoso frente a los portugueses- que ostenta el escudo de la Banda con tres castillos inscritos ${ }^{82} ; \mathrm{y}$ las efigies de Pedro López de Ayala en el monasterio de Quejana en Álava (1390$1400)^{83}$ (Fig. 7), la de Juan Alfonso de Ajofrín († 1385) en Santo Domingo el Antiguo de Toledo (1385-1390) ${ }^{84}$ (Fig. 8), o la de Alvar Pérez de Guzmán (1365-1398) en la

260-261. Conviene recordar que la Jarretera inglesa también admitía a damas en su seno, al menos desde 1376.

${ }^{81}$ Boulton, The knights of the crown, ob. cit., pp. xviii y ss.

${ }^{82}$ Se trata del sepulcro que se conserva actualmente en el Museu Frederic Marès (Barcelona) y se hallaba en el palacio-convento de Santa Isabel la Real (Toledo), en cuya portada figura el mismo escudo; cfr. María Teresa Pérez Higuera, Ferrand González y los sepulcros del taller toledano, "Boletín Seminario Arte y Arqueología Universidad Valladolid", 44 (1978), pp. 129-142; PaVón MaLdonado, Tratado de arquitectura hispanomusulmana, ob. cit., vol. III, pp. 653 y 670; María Ángela Franco MatA, El sepulcro de don Pedro Suárez III (siglo XIV) y el taller toledano de Ferrand González, "Boletín del Museo Arqueológico Nacional", 9 (1991), pp. 87-100. Quizá también parta de estos años el uso de la banda engolada entre Castilla y León que usaron tardíamente los descendientes de Pedro I -el linaje Castilla-, como sus nietos Pedro -obispo de Palencia- y Constanza († 1478); cfr. MenÉndez Pidal, Heráldica de la casa real, ob. cit., pp. 250-260.

${ }^{83}$ A la bibliografía citada hay que añadir María Lucía LAHOz, Escultura funeraria gótica en Álava, Vitoria, 1996, pp. 140 y ss.

${ }^{84}$ Balbina Martínez Caviró, Sobre los ben Furon, señores de Ajofrín, "Anales de historia del arte", 4 (1993-1994), pp. 443 y 446-447; CARDERERA y Solano, Iconografía española, ob. cit., vol. I, pp. xxvxxxvi, lámina XXXV. 


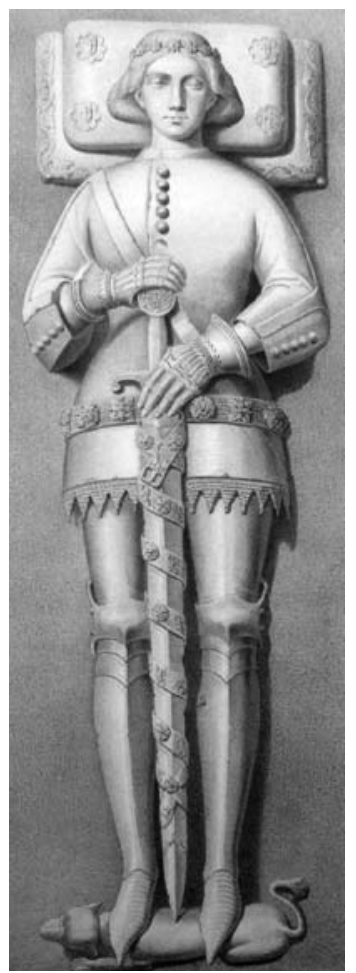

Fig. 8: Sepulcro de Juan Alfonso de Ajofrín (1385-1390), con una banda recorriendo el pecho y las mangas. Santo Domingo el Antiguo. Toledo. Dibujo: Vicente Carderera y Solano.

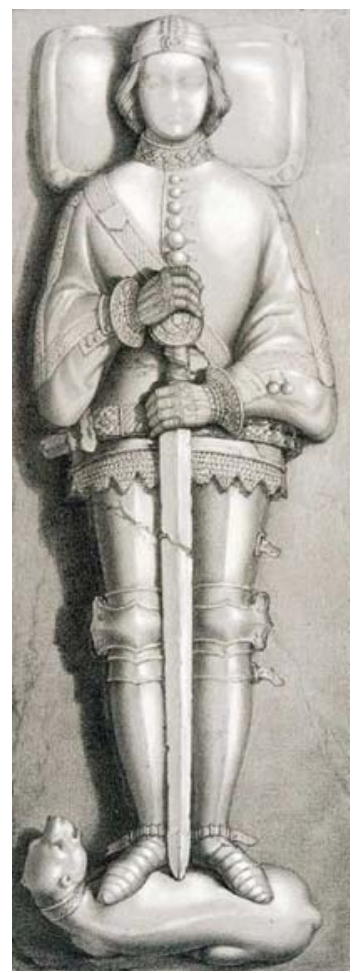

Fig. 9: Sepulcro de Alvar Pérez de Guzmán (1365-1398), con una banda decorada con escudetes recorriendo pecho y mangas. Capilla de San Andrés de la Catedral de Sevilla. Dibujo: Vicente Carderera y Solano.

capilla de San Andrés de la catedral sevillana, todos con sendas bandas que cruzan su pecho desde el hombro derecho, prolongándose después por las mangas (Fig. 9 ${ }^{85}$. La Banda también se ha identificado en el sepulcro de Fernán Pérez de Andrade o Boo $(\dagger$ 1387) - caballero favorecido por Pedro I y Enrique II- y el de su hermano Juan Freire de Andrade, ambos en la iglesia de Betanzos (La Coruña) (Fig. 10 a y b) ${ }^{86}$.

${ }^{85}$ En el caso de Alvar Pérez, la banda aparece decorada con una serie de escudetes; Pérez Higuera, Ferrand González, ob. cit., p. 138; CARDERERA y Solano, Iconografía española, ob. cit., vol. I, lámina XXV.

${ }^{86}$ Enrique Camps Cazorla, Rarezas iconográficas en San Francisco de Betanzos, "Boletín de la Comisión Provincial de Monumentos Históricos y Artísticos de Orense", 14 (1943-1944), pp. 93-94; María Dolores Fraga SAMPEdRo, San Francisco de Betanzos: nuevas aportaciones a su programa iconográfico, “Anuario Brigantino", 18 (1995), pp. 210-226; Manuel Antonio García Lamas, La memoria de Fernán Pérez de Andrade O Bóo en las iglesias de Montes do Sor: San Pantaleón de Cabanas, Santa María de Cabanas y San Paulo de Riobarba, Disponible en http://catedra.pontedeume.es/15/catedra1506.pdf. La Banda, esta vez en su representación heráldica, volverá a aparecer en los sepulcros, de comienzos del siglo XVI, de otros miembros de la familia enterrados en el monasterio de Santa María de Monfero (La Coruña), que embrazan los escudos de la Banda con dragantes: son Fernán Pérez de Andrade, segundo 
Fig. 10: a) De derecha a izquierda: sepulcro de Fernán Pérez de Andrade o Boo $(\dagger 1387)$ y su hermano Juan Freire de Andrade, con una banda cruzándoles el pecho. Iglesia de Betanzos (La Coruña). Dibujo: Xosé Antón García González Ledo.
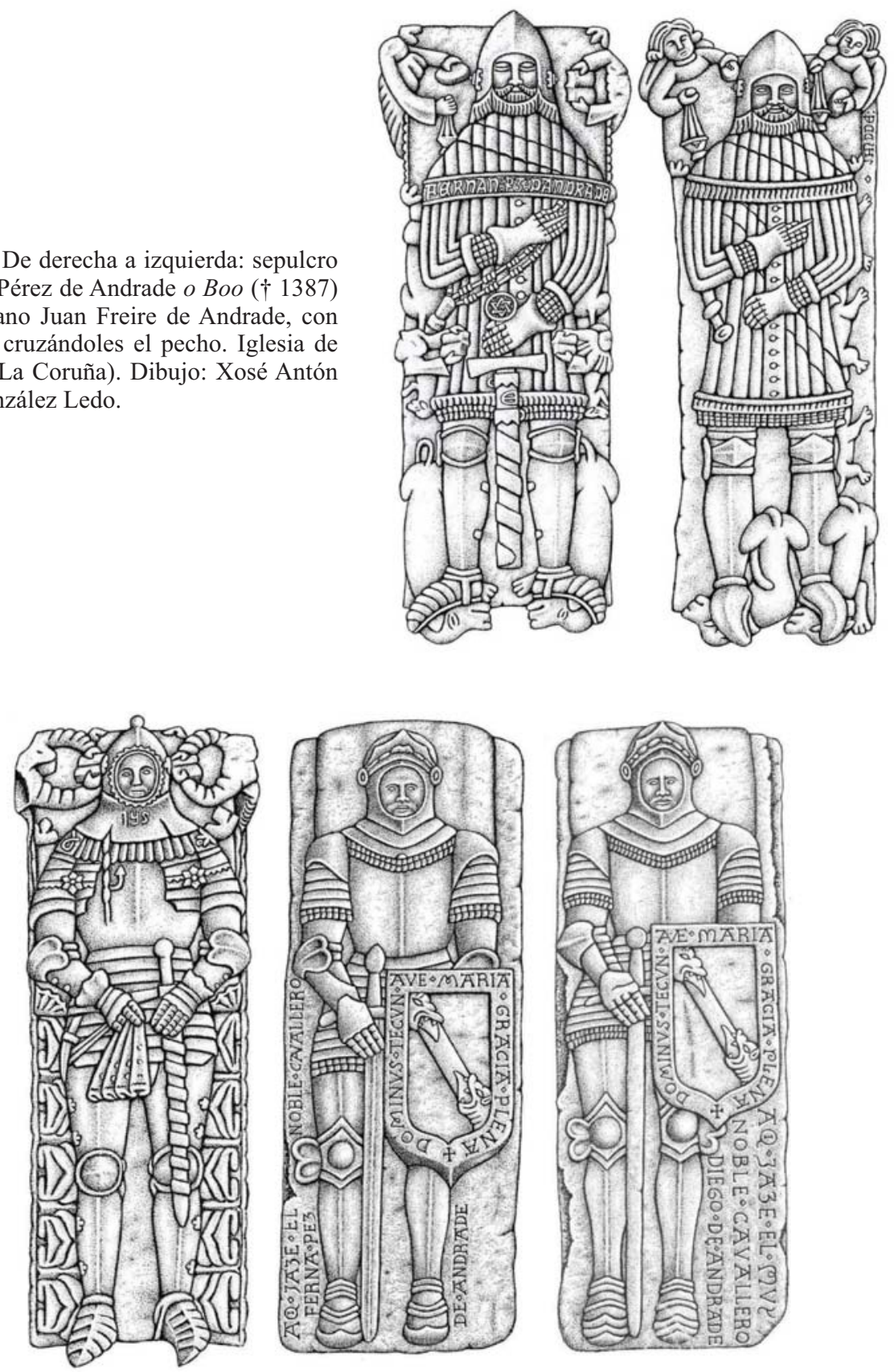

Fig. 10b: Sepulcros de Nuño Freire de Andrade, nieto del anterior, Fernán Pérez de Andrade, segundo nieto, y Diego de Andrade, tercer nieto (estos dos últimos embrazando el escudo de la Banda). Monasterio de Santa María de Monfero (La Coruña). Comienzos del siglo XVI. Dibujo: Xosé Antón García González Ledo. 
Más curioso es el sarcófago de mármol del citado Alfonso Fernández de Montemayor (c. 1390), que se hallaba en la capilla de San Pedro de la catedral de Córdoba (Fig. 11) ${ }^{87}$. Sobre la losa y sin representación del yacente, figura como único distintivo la banda adragantada que cruza de derecha a izquierda la superficie, siguiendo la misma dirección de los sepulcros toledanos y del propio adelantado en su representación del Políptico de la Virgen de la Leche. Finalmente, su representación heráldica sin dragantes también figura entre dos leones coronados en la Sala de los Reyes de la Alhambra de Granada, atribuída a Muhammad V ${ }^{88}$. Paradójicamente, toda esta difusión es coetánea a la renovación caballeresca emprendida por Juan I en 1390, quizá como reacción a las órdenes recién creadas y rápidamente abandonadas por los tutores de Enrique III en pro del antiguo sistema de la Banda.

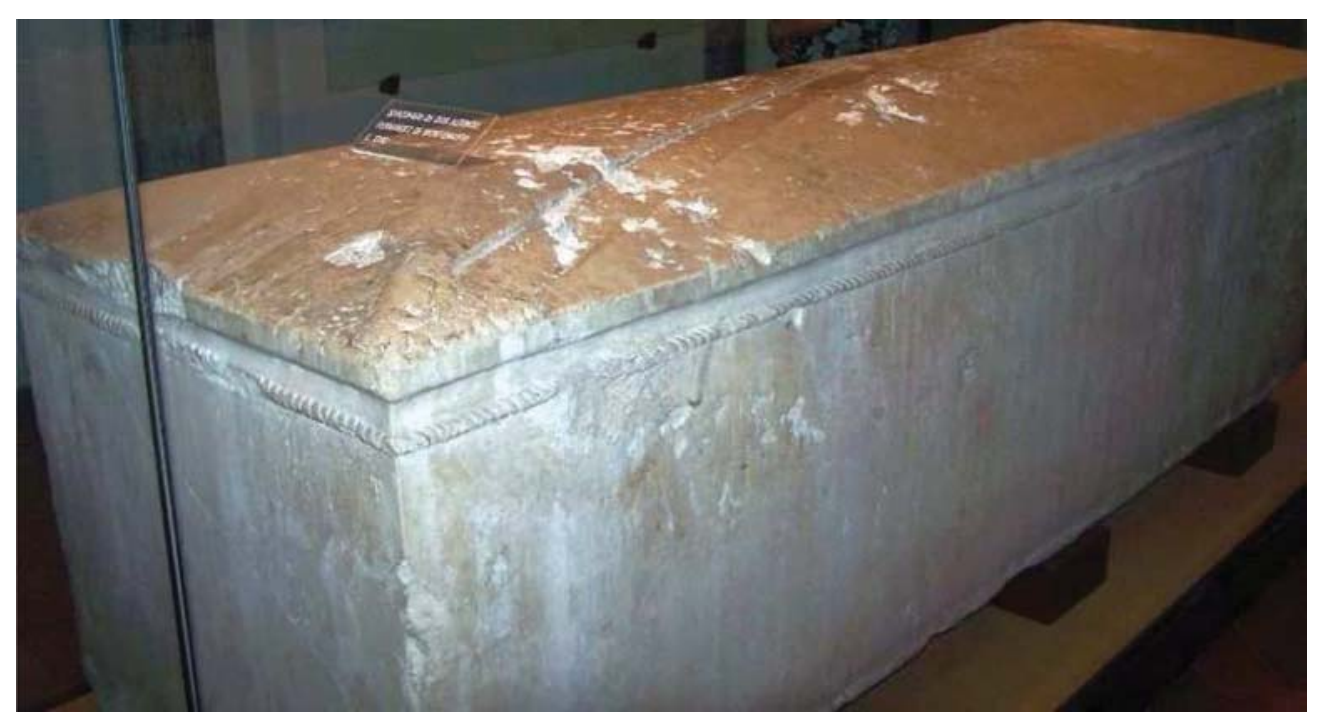

Fig. 11: Sarcófago del adelantado Alfonso Fernández de Montemayor, decorado con la banda engolada (c. 1390). Museo San Clemente. Catedral de Córdoba (Córdoba). Fotografía: Francisco Miguel Merino Laguna.

nieto de Fernán Pérez de Andrade, y Diego de Andrade, tercer nieto. Debo estos datos y el dibujo incluido en Fig. 10a y b, a la amabilidad y al conocimiento de Eduardo Pardo de Guevara y Valdés.

${ }^{87}$ El sepulcro -hoy en el Museo de San Clemente- se hallaba en la cripta elaborada bajo la cúpula de la capilla de San Pedro, en la catedral de Córdoba; cfr. Rafael Ramírez DE Arellano, Inventario monumental, ob. cit., p. 68.

${ }^{88}$ Los escudos se hallan en los extremos de la bóveda oval de dicha sala que Basilio Pavón Maldonado atribuye a Muhammad V, interpretando la escena como una teatralización de la investidura de la orden durante el período de alianza del soberano nazarí con Pedro I (1362-1469); Pavón MaLdonado, Nuevas aproximaciones, ob. cit., pp. 175-176 y 180-181; otros autores, como Balbina Martínez Caviró o Carmen Bernis, datan su ejecución en la década de 1380 en el reinado de los primeros Trastámara; Balbina Martínez CAviró, El arte mudéjar en el Convento toledano de Santa Isabel, "Al-Andalus", 36 (1971), pp. 190-195; Carmen Bernis, Las pinturas de la sala de los Reyes de la Alhambra. Los asuntos, los trajes, la fecha, "Cuadernos de la Alhambra", 18 (1982), pp. 27-51. 


\section{DE BESTIAS Y HÉROES: CRIATURAS QUIMÉRICAS DE UNA DINASTÍA PROFÉTICA}

Una de las innovaciones más originales del reinado del segundo Trastámara fue la incorporación de la emblemática regia a la nueva moda de las divisas que se extendía en los medios aristocráticos. Su irrupción se hizo sentir en el reinado de Alfonso XI, y en tiempos de Enrique II ya era una costumbre extendida entre los caballeros dorar sus divisas junto a otros pertrechos militares ${ }^{89}$. Estos adornos constituían marcas de individuación empleadas por la nueva nobleza Trastámara para superar sus oscuros orígenes que acabarían por incorporarse a su memoria funeraria, como se observa en el testamento de Pedro Fernández de Velasco - guerrero, diplomático y fiel partidario de Enrique II- que ordena en 1383 ser representado en su cenotafio "armado con todas mis armas, jaque et cota et bacinete et bubas et estoque et arnes de piernas et çapatos, et que sea puesto en ellas mis deuisas" $"$. Tales divisas podrían identificarse con las marcas florales grabadas en el bacinete y falda de su sepulcro de Medina de Pomar (c. 1384-1400), las picas florecidas que adornan la armadura de Pedro López de Ayala en el citado monasterio de Quejana ${ }^{91}$ (Fig. 7), o el jabalí emblemático que sostiene el sepulcro de Fernán Pérez de Andrade y se reproduce en otros monasterios fundados por él ${ }^{92}$.

La difusión de estos adornos en el segundo tercio del siglo XIV no seguía reglas fijas ni había oficiales que regularan su uso. Su exhibición en cimeras o adornos del yelmo ${ }^{93}$, pronto se extendió a las enseñas que servían como instrumento de identificación y comunicación en el campo de batalla, agrupando a los combatientes y estimulando sus ánimos ${ }^{94}$, como sucedió en Aljubarrota, donde "as bandeiras e os blasões era como a cada um prazia de ter, que aí não havia então Rei de Armas nem outro arauto que a ninguém desdissesse" 95 .

Aunque no faltan ejemplos de cimeras en tiempos de Sancho IV y Alfonso XI, las divisas se extendieron con la dinastía Trastámara, interesada en hacerse con su potencial emblemático y caballeresco. Enrique II hizo uso de estas marcas, pero

89 Véase el texto de las Cortes de Burgos (1379) anteriormente citado.

90 Testamento firmado en Medina de Pomar en 1483 y completado al año siguiente con un codicilo firmado en Lisboa cuando estaba a punto de fallecer a causa de la peste; cfr. Inocencio CADIÑANOS BARDECI, Obras, sepulcros y legados artísticos de los Velasco a través de sus testamentos, en El Monasterio de Santa Clara de Medina de Pomar (N. López Martínez; E. González Terán, coords.), Burgos, 2004, p. 182.

91 M. Lucía Lahoz se refiere a una "decoración vegetal de tallos curvos y rosetas" que adornan su atuendo y se repite en la banda que cruza su pecho; LAHOZ, Escultura funeraria gótica, ob. cit., p. 156.

92 Véase la bibliografía anteriormente citada.

93 El cronista portugués afirma que los castellanos usaban "todos plumões nos bacinetes que lhe davam mui grande e formosa vista"; Lopes, Chronica de El-Rei D. João, ob. cit., vol. IV, p. 146.

94 Cfr. Paul Adam, Les enseignes militaires du Moyen Âge et leur influence sur l'héraldique, en Proceedings of the Fifth International Congress of genealogical and heraldic sciences in Stockholm, 1960/Recueil du Cinquième Congrès international des sciences généalogique et héraldique à Stockholm, 1960, Uppsala, 1961, pp. 167-194; Philippe Contamine, Enseigne, en Prier et combattre. Dictionnaire européen des ordres militaires au Moyen Âge, (N. Bériou; Ph. Josserand, dirs.), París, 2009, pp. 330331.

95 Lopes, Chronica de El-Rei D. João, ob. cit., vol. IV, p. 146. 
fue con su sucesor cuando adquirieron una cierta estabilidad en la simbólica regia. Inicialmente, su temática fue zoológica desplegándose en cimeras, enseñas y otro tipo de dispositivos adornados con metales preciosos. Así lo indican los 680 maravedíes que Juan I mandó pagar al platero de la reina [Leonor de Aragón] hacia 1380 "por quanto la puso [la plata] en las devisas de los nuestros juglares, que le nos mandamos faser en Almaçan" ${ }^{96}$. Desgraciadamente no conocemos el diseño de aquel emblema elaborado en fechas tan tempranas, aunque podría estar relacionado con marcas florales grabadas en el estandarte al que se destinaron "nouenta priegos de papel para que entallaren las flores" $" 97$.

Los primeros Trastámara tuvieron una singular predilección por las criaturas fabulosas que poblaban la emblemática de los siglos XIV y XV ${ }^{98}$. Navarra fue uno de los primeros reinos hispanos en acusar su penetración, aunque su presencia sea discreta entre las cimeras datadas en las décadas de 1360-138099. En Castilla estos animales se impregnaron de la simbología difundida por la literatura caballeresca ${ }^{100}$, especialmente la artúrica que empezó a tomar cuerpo textual en el reinado de Alfonso XI, con la penetración de los vaticinios de Merlín en el Poema de Alfonso XI (1348) y en las crónicas de Pedro López de Ayala ${ }^{101}$. Se implantó entonces "la idea de ir atribuyendo a las profecías de Merlín algunos item referentes a la historia política y sucesoria de Castilla y León, que se van hilvanando de acuerdo con los sucesos habidos recientemente o esperados y que encuentran su razón de ser en el proceso

${ }^{96}$ Documento trascrito por SuÁRez Fernández, Historia del reinado de Juan I, ob. cit., vol. II, p. 296.

${ }^{97}$ Se trata del modesto pago de 9 maravedíes para la decoración del citado estandarte, enseña propia de las divisas; Ibidem, p. 296.

${ }_{98}$ Michel Pastoureau, Traité d'héraldique, París, 1997, pp. 154-158; sobre la irrupción de los monstruos en el imaginario tardomedieval cfr. Claude KaPpler, Monstruos, demonios y maravillas a fines de la Edad Media, Madrid, 2004.

99 Véase el estudio sigilográfico de Mikel Ramos Aguirre, Las cimeras en la heráldica navarra, en Actas del I Congreso Internacional de Emblemática General (G. Redondo Veintemillas, A. Montaner Frutos; M. C. García López), vol. 2, Zaragoza, 2004, pp. 845-866.

${ }^{100}$ Algunas aproximaciones a este amplio tema en María Dolores Morales MuÑIz, El simbolismo animal en la cultura medieval, "Espacio, Tiempo y Forma, Serie III, Historia Medieval", 9 (1996), pp. 229-255; David Nogales Rincón, Animalización, Sátira y Propaganda Real: la metáfora y la alegoría animal como instrumento político en la Castilla Bajomedieval (siglos XIV-XV), "Revista Signum", 11 (2010), pp. 267-296; Animales simbólicos en la historia: desde la Protohistoria hasta el final de la Edad Media (R. García Huerta; F. Ruiz Gómez, coords.), Madrid, 2012.

${ }^{101}$ Cfr. Pere Bohigas, Profecies de Merli. Altres profecies contingudes en manuscrits catalans, "Butlletí de la Biblioteca de Catalunya", 8 (1928-1932), pp. 253-279; Joaquín Gimeno CASALduero, La profecía medieval en la literatura castellana y su relación con las corrientes proféticas europeas, en ID., Estructura y diseño en la literatura castellana medieval, Madrid, 1975, pp. 103-141, especialmente pp. 130 y ss; Simone PINET, El baladro del sabio Merlín: notas para la historia y caracterización del personaje en España, México, 1997; Pedro María CÁtedra, y Jesús Demetrio Rodríguez Velasco, Creación y difusión de El balandro del Sabio Merlín, Salamanca, 2000; y su interesante aplicación política analizada por Sylvia RouBAud, La prophétie merlinienne en Espagne: des rois de GrandeBretagne aux rois de Castille, en La prophétie comme arme de guerre des pouvoirs (XV'-XVII siècles) (A. Redondo, ed.), Paris, 2000, pp. 160-163; Isabelle RousseaU-J $\mathrm{JCOB}_{\mathrm{ACO}}$ La prophétie comme outil de légitimation: trois lectures du Vae Mundo (XIV siècle), en Lucha política: condena y legitimación en las sociedades medievales (I. Alfonso, J. Escalona, G. Martin, dirs.), Lyon, 2004, pp. 63-100; María Mercè LóPez CASAS, Las profecías de Merlín y la legitimación de los Trastámara, en Magia, brujería y esoterismo en la Historia (A. Víñez Sánchez; S. Moreno Tello, coords.), Cádiz, 2005, pp. 45-62. 
de exégesis a que los autores someten a estos cuerpos proféticos" ${ }^{\text {"102 }}$. Desde el punto de vista emblemático, interesa subrayar que este profetismo utilizaba modelos estéticos encarnados en animales de diverso grado de salvajismo o nobleza, que se identificaban por un detalle o color pudiendo vincularse a determinadas personalidades o acontecimientos históricos a los que dotaba de un pasado mítico y legitimador.

\subsection{LA PROFECÍA DEL DRAGÓN}

Una de estas criaturas fue el dragón, en sus variantes de sierpe, serpiente o ydra, que el imaginario medieval representaba como un animal grandioso, temible y admirado, con cuerpo de reptil, aletas de pez, garras de león y alas de águila. Se fusionaban de esta forma las características propias de los animales terrestres, acuáticos, aéreos ${ }^{103}$, añadiendo el dominio sobre el cuarto de los elementos esenciales, el fuego, gracias a su capacidad de arrojarlo con su aliento ${ }^{104}$. Con semejante poder el dragón se difundió en ambientes caballerescos como símbolo de independencia, jefatura y fuerza, en un fenómeno de apropiación simbólica de las cualidades de la bestia por parte del héroe ${ }^{105}$. El emblema septiforme podía interpretarse entonces como el trofeo que exalta el valor de su captor, ofreciéndose al mismo tiempo como objeto de admiración ${ }^{106}$. En esta línea se sitúan los cultos ofilátricos paganos tan comunes en la Antigüedad como Apolo sauróctono. Según San Isidoro de Sevilla (Etimologias, 14, 6, 10), su lucha mitológica con la serpiente Pitón inspiraría los estandartes militares de griegos y romanos, aportando una prestigiosa referencia sígnica a la emblemática medieval. En varios pasajes de la Biblia y en ciertos modelos hagiográficos, pueden encontrarse lecturas conciliadoras de este animal convertido en compañero o defensor de los santos $^{107}$, como la vara de Moisés que arrojada en la tierra se transforma en serpiente

102 Cátedra García, y Rodríguez Velasco, Creación y difusión, ob. cit., p. 38.

${ }^{103}$ Cfr. Pilar Montero Curiel, y María Luisa Montero Curiel, El léxico animal del "Cancionero de Baena", Madrid, 2005, pp. 164-171.y 319-324; sobre su compleja morfología y rico simbolismo cfr. José Antonio Pérez Rioja, Diccionarios de símbolos y mitos, Madrid, 1962, p. 181; Maxime Chevalier, Diccionario de los símbolos, Barcelona, 1988, pp. 823-825; KAPPler, Monstruos, demonios y maravillas, ob. cit., pp. 66, 105, 125, 220-297 y 336-337; Jacques VoISENET, Bêtes et Hommes dans le monde médiéval. Le Bestiaire des clercs du V $V^{e}$ au XIII siècle, Turnhout, 2000, pp. 22-25.

${ }^{104}$ La mitología desarrolló sus cualidades defensivas, su fuerza, agilidad y vista extraordinaria (expresada en su etimología griega derkein=ver) que ejercita como guardián de las manzanas de oro en el jardín de las Hespérides, u otros tesoros que custodia en su guarida como bestia vinculada con lo terrenal y las fuerzas desordenadas de la naturaleza.

${ }^{105}$ El difundido bestiario de Brunetto Latini lo considera "la mayor serpiente que todas las otras, e aún que ninguna de todas las bestias"; Spurgeon BALDwIN (ed.), The Medieval Castilian Bestiary from Brunetto Latini's Tesoro: Study and Edition. Brunetto Latini, University of Exeter, 1982, pp. 13 y ss; Ignacio MalaXecheverría Rodriguez (ed.), Bestiario medieval, Madrid, 1986, pp. 180-181.

106 Debo esta idea a la sabiduría de Ángel Gómez Moreno, que ha tenido ocasión de tratar temas semejantes en su excelente trabajo Ángel Gómez Moreno, Claves hagiográficas de la literatura española (del Cantar de mio Cid a Cervantes), Madrid-Francfort, 2008; sobre la escasa presencia del dragón en el campo heráldico y su irrupción en el terreno más libre de las divisas cfr. PASTOUREAU, Traité d'héraldique, ob. cit., p. 154.

${ }^{107}$ Véanse por ejemplo los dragones que habitaban la cueva escogida por el Niño Jesús en su viaje a Egipto y se doblegan ante su presencia; Castigos e documentos del rey don Sancho; cfr. John K. WALSH, The chivalric dragon: hagiographic parallels in early Spanish romances, "Bulletin of Hispanic 
alada que el profeta emplea para conducir al pueblo elegido (Ex, 4, 1-5). En el pasaje del libro de los Números (Números 21, 4-9), el dragón se constituye en figura de Cristo cuando Moisés hace levantar su efigie en el desierto para sanar a los mordidos por la plaga de serpientes, anunciando la salvación del género humano cuando el Hijo de Dios fuera levantado sobre la cruz $(\mathrm{Jn}, 3,14)^{108}$.

La literatura castellana debió apoyarse en esta tradición al convertir al dragón, no sólo en digno rival ${ }^{109}$, sino en colaborador del héroe ${ }^{110}$, con el que llega a identificarse; como sucede en el Amadís de Gaula, donde los dragones profetizados por el ermitaño -"que ternían su señorío en Gaula, e sus corazones en la Gran Bretaña"-representaban a Amadís y Galaor en su atributo primordial y caracterizador: la grandeza y magnanimidad de corazón ${ }^{111}$. De ahí que en la Europa tardomedieval se introdujeran representaciones draconianas, realizadas con mimbres y telas, en los festejos urbanos o cortesanos documentados inicialmente en Valencia en la entrada del infante Joan (1373) y difundidos posteriormente en Cataluña, Valencia o Navarra ${ }^{112}$

Desde el punto de vista emblemático, el dragón experimenta una gran difusión ibérica en el segundo cuarto del siglo XIV. Felipe III de Navarra lo usó en sus

Studies”, 54 (1977), pp. 189-198; Jacques LE GoFf, Cultura eclesiástica y cultura folklórica en la Edad Media: San Marcelo de París y el dragón, en ID., Tiempo, trabajo y cultura, Madrid, 1983, pp. 223-263.

${ }^{108}$ Comentarios de algunos Padres de la Iglesia y autores medievales sobre la equiparación dragónCristo en Olivier BeigBeder, Léxico de los símbolos, Madrid, 1995, pp. 375-377; la sierpe de la vara de Aarón se plantea como referente bíblico del dragón que timbra las armas portuguesas en João Paulo de Abreu Lima, Armas de Portugal. Origem. Evolução. Significado, Lisboa, 1998, pp. 106 y ss; sus connotaciones negativas como animal diabólico identificado con el Islam en Jurgis BALTRUŠAITIS, Le Moyen Áge fantastique. Antiquités et exotismes dans l'art gothique, París, 1993, pp. 156-161; MonTERo Curiel, y Montero Curiel, El léxico animal, ob. cit., pp. 321-324.

109 Recuérdese el dragón que custodiaba el jardín de las Hespérides y fue vencido por Hércules, como se relata en 1417 en EnRIQue De Villena, Los doce trabajos de Hércules, ed. P. Cátedra y P. Cherchi Usai, Santander, 2007, cap. VIII, pp. 53-56. Las "sierpes e muy fuertes dragones" que habitaban el paraíso caballeresco de Inglaterra para Gutierre Díez de Gamés; Gutierre DíEz DE GAMÉs, El victorial, ed. de R. Beltrán Llavador, Salamanca, 1997, cap. LXXXIX. Sus orígenes emblemáticos se hacen remontar a Apolo "por razon de la muerte de Phiton, la serpiente; e dende adelante los griegos e romanos acostumbraron traher insignias de dragones"; Alfonso de Toledo, Invencionario, ed. Philip O. Gericke, Madison, 1992, tít. VII, cap. VIII, p. 64. Sobre la presencia del dragón en la literatura castellana cfr. Antonio Garrosa Resina, La tradición de animales fantásticos y monstruos en la literatura medieval española, "Castilla", 9-10 (1985), p. 87; Francisco Crosas LóPEZ, La materia clásica en la poesía de Cancionero, Reichenberger, 1995, pp. 53-57; Carlos Alvar, Dragones, en ID., Diccionario de leyendas artúricas, Madrid, 2004, pp. 136-138.

${ }^{110}$ La Gran Serpiente del Amadís transporta a la bondadosa hada Urganda la Desconocida, y facilita la investidura caballeresca del jovencísimo Esplandián con sus cuatro donceles, recibiendo por ello el sobrenombre de "el caballero de Gran Serpiente"; Lilia E. Ferrario de OrdunA, Amadís de Gaula. Estudios sobre narrativa caballeresca castellana en la primera mitad del siglo XVI, Reichenberger, 1992, p. 157.

111 Cfr. Eloy González Argüelles, Función de las profecías en el Amadís de Gaula, "Nueva Revista de Filología Hispánica”, 31 (1982), pp. 284-285.

112 Anca Bratu, "Dragon", en Dictionnaire Encyclopédique âu Moyen Age (André Vauchez, dir.), vol. I, París, 1997, pp. 482-483; Francesc MAssip BONET, La monarquía en escena: teatro, fiesta y espectáculo del poder en los reinos ibéricos, de Jaume El Conquistador al Príncipe Carlos, Madrid, 2003, pp. 45-53. 
improntas sigilares en $1329^{113}$, y Pedro IV de Aragón como cimera a partir de 1343 (Fig. $12)^{114}$ con vínculos más o menos explícitos con el murciélago (vespertillio) que Arnau de Vilanova identifica en sus profecías con el monarca universal que subyugará África, restaurará España y traerá la paz al mundo ${ }^{115}$. Noshallamos portantoanteun dragón profético que personifica al soberano en un fenómeno mimético semejante al que experimentaban los héroes literarios caballerescos. Por último, hay que citar a Fernando I de Portugal (13671383), de quien se documenta el uso de una sierpe alada timbrando las armas reales, que ha sido relacionada con el dragón aragonés en una operación de "cerco heráldico" al león de Castilla durante su alianza contra Enrique II ${ }^{116}$.

En la corte castellana, María de Molina (c. 1264-1321) adornaba sus armas con unas serpientes ${ }^{117}$, años antes de que su nieto

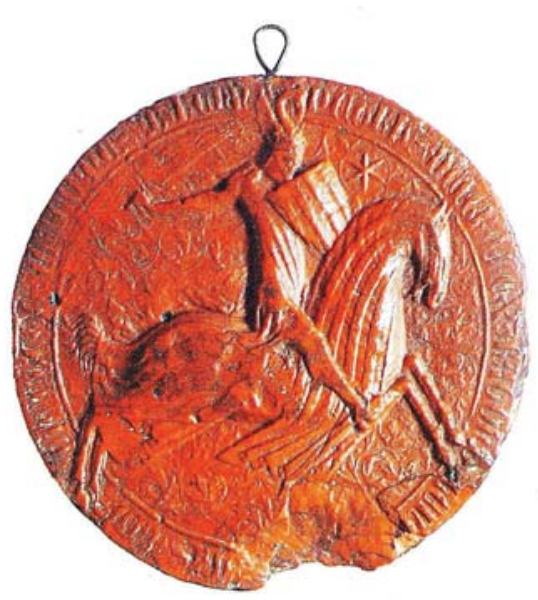

Fig. 12: Pedro IV de Aragón portando la cimera del dragón alado (c. 1343-1344). Impronta suelta del $2^{\circ}$ sello mayor de Pedro IV. Real Academia de la Historia. Madrid.

${ }^{113}$ Faustino Menéndez Pidal, Mikel Ramos Aguirre, y Esperanza Ochoa de Olza Eguiraun, Sellos medievales de Navarra. Estudio y corpus descriptivo, Pamplona, 1995, p. 126, fig. 1/57.

114 Véase la impronta sigilar con la representación ecuestre de Pedro IV portando la cimera del dragón alado (c. 1343-1344), conservada en la Real Academia de la Historia (n. GN4/637) y reproducida en Tesoros de la Real Academia de la Historia, Madrid, 2001, p. 298. La adopción de esta divisa como cimera por parte de Pedro IV es simultánea al uso del mantelete con el señal de Aragón (cuatro palos de gules en campo de oro) a partir de 1337, y cabe pensar que la elección se pudo ver influida por la paronomasia dragón = d'Aragón. Recientemente, se ha identificado una representación de la divisa (dragón dorado pasante con la cabeza contornada y sobre fondo rojo) en un alfarje del Salón de Recepción de la Aljafería (Zaragoza) datado en tiempos de Pedro IV -entre 1356 y 1379-que muestra el uso de figuras emblemáticas exentas antes del reinado de Juan I; cfr. Montaner Frutos, Testimonios heráldicos, ob. cit., vol. II, pp. 129-131. La conexión de la cimera del rey aragonés con las corrientes proféticas en Duran y Requesens, Profecia i poder, ob. cit., pp. 59-62.

115 Sobre la compleja simbiosis del murciélago y del dragón alado en la tradición heráldica aragonesa cfr. Andreu Ivars CArdona, Orige i significació del «Drach Alat» $i$ del «Rat Penat» en les insígnies de la ciutat de València, Valencia, 1962; Menéndez Pidal de NAvascués, Símbolos de España, ob. cit., pp. 95-138; su sentido mesiánico fue abordado por Alain MiLnou, La chauve souris, le Nouveau David et le Roi Caché (trois images de l'empereur des derniers temps dans le monde ibérique: XII'-XVII siècles), "Mélanges de la Casa de Velázquez", 18-1 (1982), pp. 61-78; Alberto Montaner Frutos, El señal del rey de Aragón: historia y significado, Zaragoza, 1995, pp. 68-74; ID., Testimonios heráldicos, ob. cit., pp. 119-145.

${ }_{116}$ Lima, Armas de Portugal, ob. cit., pp. 102-106; Miguel Metelo de SeIXas, El simbolismo del territorio en la heráldica regia portuguesa. En torno a las armas del Reino Unido de Portugal, Brasil y Algarbes, "Emblemata", 16 (2010), pp. 299-300; aunque también podría derivar de las sierpes castellanas usadas por María de Molina y trasmitidas por su hija Beatriz de Castilla y Molina (1293135), abuela de Fernando I.

${ }^{117}$ El tapiz de la esposa de Sancho IV es descrito como "un paño de lana de pared, a castillos et a leones, et sierpes en derredor"; Mercedes Gaibrois Riaño de Ballesteros, María de Molina, Pamplona, 2011, p. 37. 
Alfonso XI (1312-1350) introdujera las cabezas de dragantes en la representación de la Banda durante la campaña de Salado, en que el monarca también entrega dos dragones como armas a Alfonso Fernández Valdespino, alférez mayor de Jerez de la Frontera $^{118}$. De hecho no resulta difícil imaginar a este animal codeándose con las fantasiosas cimeras de los caballeros "de fuera del regno" que acudieron al cerco de Algeciras en $1343^{119}$.

En tiempos de Enrique II el dragón pudo asumir una dimensión profética por contagio con el espíritu visionario aragonés que se difundía durante el Cisma de Occidente y las guerras civiles de los tres Pedros de España (Pedro IV de Aragón, Pedro I de Castilla y Pedro I de Portugal). En Castilla esta corriente aflora en las profecías de Merlín que justifican el advenimiento de los Trastámara, insertándose en el Poema de Alfonso XI (1348) y en la crónica de Pedro I antes del relato de la batalla de Montiel (1369) ${ }^{120}$. Enrique de Trastámara pudo conocer estas ideas durante su exilio en Aragón, donde nació su primogénito y se fraguó la alianza con Pedro el Ceremonioso para destronar a su hermanastro ${ }^{121}$. El trasvase profético se documenta hacia 1377 en la obra del infante Pedro de Aragón, cuarto hijo de Jaime II de Aragón y tío del Ceremonioso, que operó una trasposición de la misión mesiánica de los catalanes, descendientes de Federico II Hohenstaufen, a beneficio de los Trastámara, convirtiendo a Enrique II de Castilla en el murciélago del Vae mundo que acabaría con Pedro I cortándole la cabeza, y después convertiría a los infieles, "según todas las profecías de Merlín, del abad Joaquín [de Fiore], del fraile Johan de Rupecisa [Juan de Rocatallada], de Vae mundo in centum annis, del ermitaño de la Lamposa y de otros que tenían espíritu de profecía" ${ }^{122}$. Una identificación que coincidía con la procedencia oriental del restaurador que devolvería la concordia al pueblo castellano.

Las consecuencias emblemáticas de estos trasvases proféticos podrían rastrearse en el retablo de Nuestra Señora de Tobed (Zaragoza) (c. 1368-1373) donado por Enrique II a la iglesia-fortaleza homónima, donde se habría refugiado durante el conflicto

${ }^{118}$ Véase el documento fechado en Tarifa el 30 de octubre de 1340, en Manuel García FernándeZ, Regesto documental andaluz de Alfonso XI, 1312-1325, "Historia. Instituciones. Documentos", 15 (1988), p. 75.

119 Véase su descripción y el asombro provocado entre los musulmanes que "fueron muy maravillados del poder del Rey"; Crónica de Alfonso Onceno, ed. Francisco Cerdá y Rico, Madrid, 1787, pp. 556-557.

${ }^{120}$ Germán Orduna, Crónica del rey Don Pedro y del rey Don Enrique, su hermano, hijos del rey don Alfonso Onceno, Buenos Aires, 1997, pp. 270-274; López CASAs, Las profecías de Merlín, ob. cit., pp. 52 y 55.

121 Joaquín de CARPI CASES, El principado de Asturias, creación de un tamaritano, "Argensola: Revista de Ciencias Sociales del Instituto de Estudios Altoaragoneses”, 87 (1979), pp. 233-246; ID., Historia de Tamarite de Litera:(desde sus inicios hasta el siglo XX), Ayuntamiento de Tamarite de Litera, 2008, p. 348.

${ }^{122}$ La identificación es clara: "en lo vespertilió o rata-penada és significat e figurat lo rey Enric"; José Pou, Visionarios, beguinos y fraticelos catalanes (siglos XIII-XV), Vic, 1930, pp. 370-371; Eulàlia Duran y Joan Requesens, Profecia i poder al Renaixement. Texts profétics catalans favorables a Ferran el Catòlic, Valencia, 1997, pp. 37-38; LóPez i CASAs, Las profecías de Merlín, ob. cit., p. 58. El monarca castellano se equipara también al león pues "leo hispanus draco efficitur", como señalaba Rocatallada en su comentario del Vae mundo contenido en el Liber ostensor (1356); Josep Perarnau Espelt, La traducció catalana medieval del "Liber secretorum eventuum" de Joan de Rocatalhada, "Arxiu de textos catalans antics", 17 (1998), pp. 35-36; RousSEAU-JACOB, La prophétie comme outil de légitimation, ob. cit., p. 79. 
sucesorio y que sostuvo después con su mecenazgo ${ }^{123}$. En el retrato del monarca y el príncipe Juan como donantes, figura la única divisa personal documentada para Enrique II. Se trata de la parte anterior de una criatura alada, con garras amenazantes, que adorna la cimera de su yelmo y de su primogénito (Fig. 3$)^{124}$. Debido al mal estado de la pintura Menéndez Pidal identificó la cimera del padre con un dragón sin alas o una pantera heráldica de color dorado, y la de su hijo con una garza o un cisne blanco $^{125}$. Las obras de restauración han permitido precisar mejor la morfología de ambos animales que sólo se distinguen por el tamaño y son más bien grifos, como veremos más adelante.

El hipotético dragón de Tobed podría relacionase con las profecías de inspiración catalano-aragonesa, teniendo en cuenta la atribución del retablo a un taller barcelonés y su ubicación en la localidad zaragozana. Esta interpretación convertiría a los primeros Trastámara en los dragones victoriosos procedentes del Oriente (¿exilio aragonés?) o "montaña del dragón" - como lo designan las Profecías de Merlín cerca de la ciudad de Londres (1370) ${ }^{126}$-, cuya ferocidad recuerda al dragón alado que

${ }^{123}$ El santuario zaragozano dependía de Lope Fernández de Luna, arzobispo de Zaragoza y protector de Juana Manuel de Villena, esposa de Enrique II; el patronazgo de éste último ha dejado su huella en las armas de Castilla y León representadas en diversos lugares de la iglesia datados después de 1359. Recientemente Rosa Alcoy i Pedros considera que el retablo debió componerse entre 1359-1363 como exvoto ofrecido por el aspirante al gobierno castellano. Dejando abierta la posibilidad de que por estas fechas pudiera plantearse el encargo, lo cierto es que su elaboración debe postergarse a 1366, atendiendo a las armas reales y la corona allí representadas y que Enrique II pudo usar desde su proclamación en marzo de este año. La edad del infante (entre 10 o 15 años), permite a Faustino Menéndez Pidal precisar aún más las fechas entre 1368 y 1373, mientras Luis Condor Abanto la retrasa a 1375, en que se firma el Tratado de Almazán que restablece las relaciones entre Castilla y Aragón, y un año después del fallecimiento de la princesa Juana (1367-1374), ausente en la obra. Para este último autor, Enrique II efectuaría el encargo a un taller barcelonés en agradecimiento por haber salvado la vida en la batalla de Nájera (1367) y haber conseguido el trono. Por su parte Olga Pérez Monzón ha subrayado las intenciones legitimadoras de este "retrato de familia" nada más acceder al trono la nueva dinastía, colocando en posición preferente las armas de la reina por recibir de ella la descendencia legítima, como señala Menéndez Pidal; cfr. MenÉndez Pidal, Símbolos de España, ob. cit., p. 93 (a quien agradezco las precisiones cronológicas comentadas más arriba); María Angeles Blanca PiQuero LóPEz, "Virgen de Tobed", en Maravillas de la España Medieval. Tesoro sagrado y monarquía (Isidro BAngo ToRviso, dir.), Valladolid, 2001, p. 443-445; Olga PéRez Monzón, La dimensión artística de las relaciones de conflicto, en La monarquía como conflicto, ob. cit., pp. 568-569; Katharina PIEPER, La Virgen de Tobed: observaciones sobre la datación de la iglesia, en $3^{a}$ Jornadas de Estudio de la Orden del Santo Sepulcro, Zaragoza, 1999, pp. 287-297; Rosa AlCoy i Pedros, Pintura y debate dinástico: los retablos de Enrique de Trastámara y Juana Manuel en Santa María de Tobed, en El romànic i el gòtic desplaçats. Estudis sobre l'exportació i migracions de l'art català medieval (R. Alcoy; P. BeSERAN, ed.), Barcelona, 2007, pp. 185 y ss; Luis Condor Abanto, La iglesia de Santa María de Tobed. Patrimonio de la Humanidad, "Cuadernos de Aragón”, 45 (2010), pp. 98-99.

124 Menéndez Pidal, Heráldica de la casa real, ob. cit., p. 265; González Díez, y Martínez Llorente El blasón heráldico, ob. cit., p. 222; se ha identificado también con una pantera dorada, evocadora de los leopardos ostentados por el Príncipe Negro; cfr. José María de Montells y Galán, El uso de la cimera en la Heráldica española, "Revista Iberoamericana de Heráldica", 1 (1993), pp. 35-36.

125 Menéndez Pidal de Navascués, Menéndez Pidal, Heráldica de la casa real, ob. cit., p. 167.

126 Se trata de las "cosas que han de contecer en España, y todas las conquistas de España como han de ser partidas cada vna sobre si", donde el profeta bretón distingue la parte occidental ("selva de la oceria de las aguas fondas"), la septentrional ("estremadura"), meridional ("la gran fumera") y "la otra parte de Oriente [que] será llamada la montaña del dragón"; BonILla y SAN MARTín (ed.) Libros 
abate con sus uñas enponçoñadas a su rival sin alas en la profecía de la Demanda del Santo Grial ${ }^{127}$. La metáfora zoológica no era nueva, pues ya se encontraba en las Prophetiae Merlini (c. 1135) que comparaban la rivalidad de los hijos de Guillermo el Conquistador con el enfrentamiento de dos saurios ${ }^{128}$. De confirmarse esta contaminación, nos hallaríamos ante una sugestiva trasposición de la materia de Bretaña en la emblemática ibérica en un contexto de rivalidad entre unos soberanos -Pedro IV de Aragón, Enrique II de Castilla y Fernando I de Portugal- que usaban contemporáneamente el dragón como elemento para-heráldico.

Aunque haya que descartar la presencia del dragón en el retablo de Tobed, este animal quimérico figura en otras representaciones. Oliveira Martins identificó al reptil alado en la "bandeira del Rey de Castela" que Antão Vasques entregó al maestre de Avis al final de la batalla de Aljubarrota. Sin embargo, la referencia debe ser fruto de la libertad interpretativa del historiador ochocentista, útil para enfatizar la oposición del dragón Trastámara y el San Jorge de los Avis ${ }^{129}$. Más seguros son los dragones tenantes que flanquean las armas del infante Fernando (de Antequera), timbradas por un yelmo con cimera en forma de grifo (Fig. 13) ${ }^{130}$. Se trata del sello que Juan I le concedió "con grande solemnidad" en las Cortes de Guadalajara de $1390^{131}$, y se corresponde con la impronta de 1395 conservada en el Archivo Histórico Nacional.

Años más tarde, el dragón pudo inspirar la divisa del collar de la Escama del joven Juan II, creada por sus tutores entre 1404 y 1410, imitando la piel del fabuloso reptil para distinguirla de la representación figurativa adoptada por Segismundo de Hungría o Juan I de Foix ${ }^{132}$. De esta manera, Fernando de Antequera podía conservar el grifo, convertido desde 1402 en animal simbólico de su propia orden, mientras cedía a su sobrino el dragón para su orden de la Escama creada con un sentido de protección. Tal vez por ello, el joven monarca era identificado por Ruy Páez de Ribera con el bravo dragón, en los versos que celebran su acceso a la mayoría de edad según las

de caballerías, vol. I: Ciclo artúrico-Ciclo carolingio, Nueva Biblioteca de Autores Españoles, vol. VI, Madrid, 1907, p. 157.

127 "E el [dragón] que ouiere voz, traerá mal al otro sin alas; e fincarle ha en la frente las uñas enponçoñadas, e la vengança auran los otros, e mataran uno a otro"; BonILLA y SAN MARTín (ed.) Libros de caballerías, ob. cit., p. 22.

${ }^{128}$ Edmond Faral, La legende arthurienne: études et documents, vol. III, París, 1969, pp. 190-192.

${ }^{129}$ Debo esta aclaración a Miguel Metelo de Seixas cfr. Joaquim Pedro Oliveira Martins, A vida de Nun 'Alvares. Historia do estabelecimento da dynastia de Aviz, Lisboa, 1893, pp. 280 y 283.

${ }^{130}$ Su impronta de 1395 se describe en Araceli Guglieri Navarro, Catálogo de sellos, ob. cit., vol. I, n. 708, p. 526; una reproducción en MenÉNdez Pidal, Heráldica de la casa real, ob. cit., pp. 347-348; más claro es el dibujo incluido en ID., La Heráldica medieval española. I. La casa real de Castilla y León, Madrid, 1982, pp. 183 y 189; tanto Faustino Menéndez Pidal como Araceli Guglieri Navarro describen las divisas en posición inversa a como figuran en la imagen.

131 "El mismo día con grande solemnidad mandó el Rey señalar las armas y devisas del Infante, porque era costumbre en aquellos tiempos que los Infantes diferenciaban sus armas de las armas reales que tenían los Reyes y sus hijos primogénitos"; Jerónimo de Zurita, Anales de la Corona de Aragón, Libro XVI, cap. XXVIII, vol. IV, Valencia, 1973, p. 748.

${ }^{132}$ Cfr. Klaus H. FedER, Die ritterliche ungarische Gesellschafft vom Drachen (Societas draconis), "Zeitschrift der Österreichischen Gesellschaft für Ordenskunde", 36 (1999), pp. 1-20; Peter Shervey LEWIS, Une devise de chevalerie inconnue, créée par un Comte de Foix?: le Dragon, "Annales du Midi", 76 (1964), pp. 77-84. Sobre la orden de la Escama cfr. Fernández de Córdova, Las divisas del rey: escamas y ristres, ob. cit., pp. 26-27. 

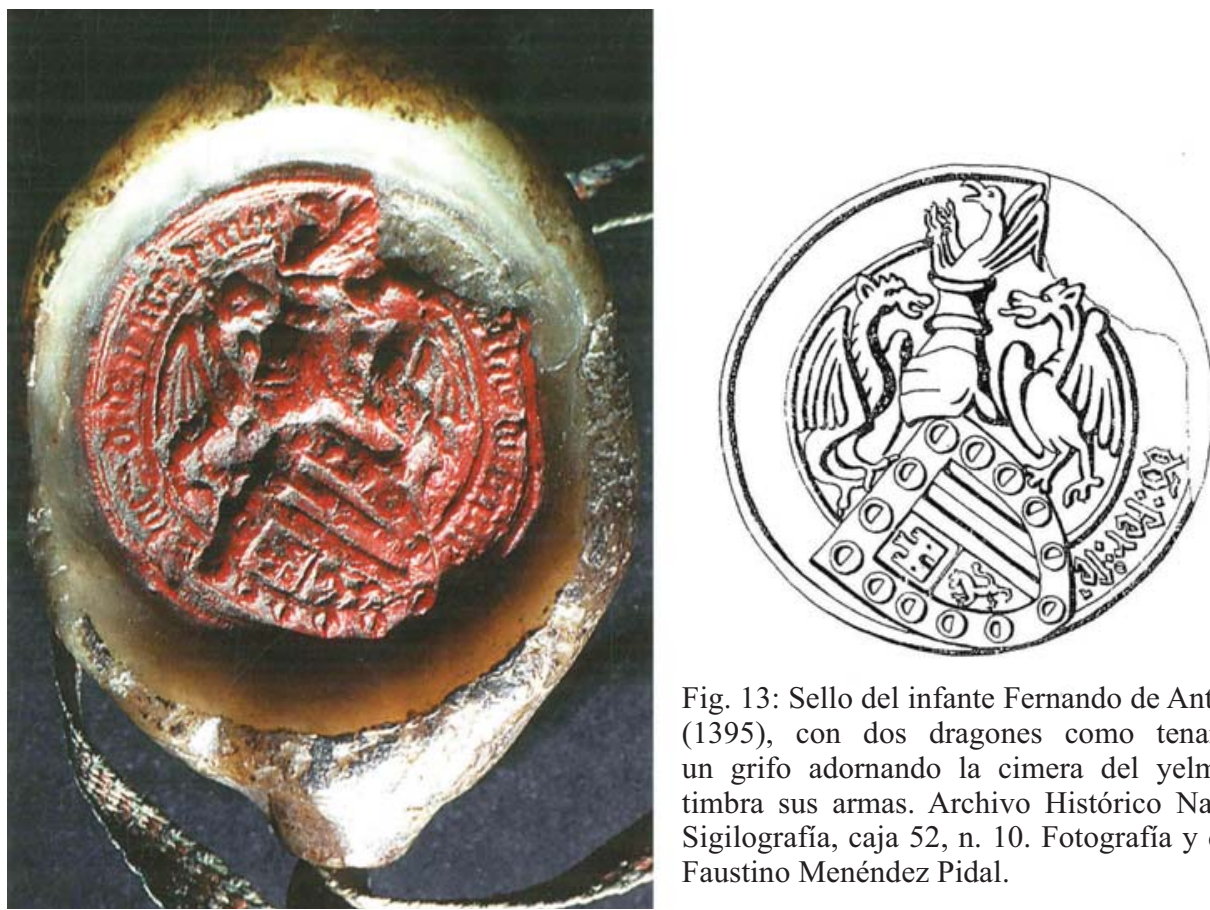

Fig. 13: Sello del infante Fernando de Antequera (1395), con dos dragones como tenantes y un grifo adornando la cimera del yelmo que timbra sus armas. Archivo Histórico Nacional, Sigilografía, caja 52, n. 10. Fotografía y dibujo: Faustino Menéndez Pidal.

coordenadas del profetismo merliniano que solía activarse en momentos de tensión política ${ }^{133}$. Y aunque su recuerdo se fue difuminando de la memoria Trastámara, su figura aún aparece junto a otras divisas dinásticas en la bóveda estrellada de la Casa del cordón de Vitoria, decorada hacia 1492 (Fig. 14a) ${ }^{134}$.

\subsection{EL GRIFO DORADO DE LOS TRASTÁMARA}

Mayor peso que el dragón tuvo otra criatura fabulosa que pudo distinguir mejor a los Trastámara de otras dinastías ibéricas. Nos referimos al grifo dorado: criatura híbrida que une el poder terrestre y la nobleza del león (mitad inferior) al dominio celeste y la aguda vista del águila (mitad superior) (Fig. 14b). Su doble morfología también implicaba una ambivalencia simbólica como bestia peligrosa que "haze muchas males a ombres e cauallos"135, y animal crístico por su doble naturaleza (humana-

133 Dezir que fizo e ordenó el dicho Ruy Páez de Ribera como a manera de metáforas escuras quando andaba la división en el regno en tiempo de la señora reina doña Catalina por la muerte del Rey don Fernando de Aragón; en Cancionero de Juan Alfonso de Baena, ed. B. Dutton y J. González Cuenca, Madrid, 1993, pp. 517-518.

134 Las divisas (grifo de Fernando de Antequera, yugo de Fernando el Católico, águila de San Juan y flechas de la reina Isabel) se representan en las claves de esta bóveda recientemente restaurada que levantó el comerciante Juan Sánchez de Bilbao en su palacio urbano hacia 1492.

135 Bartolomeus Glanville (Bartholomaeus Anglicus), Liber de proprietatibus rerum, traducción de fray Vicente de Burgos, ed. Enrique Meyer, Tolosa, 1494, cap. XX: Del grifo e de sus propiedades, f. $283 \mathrm{rv}$. 

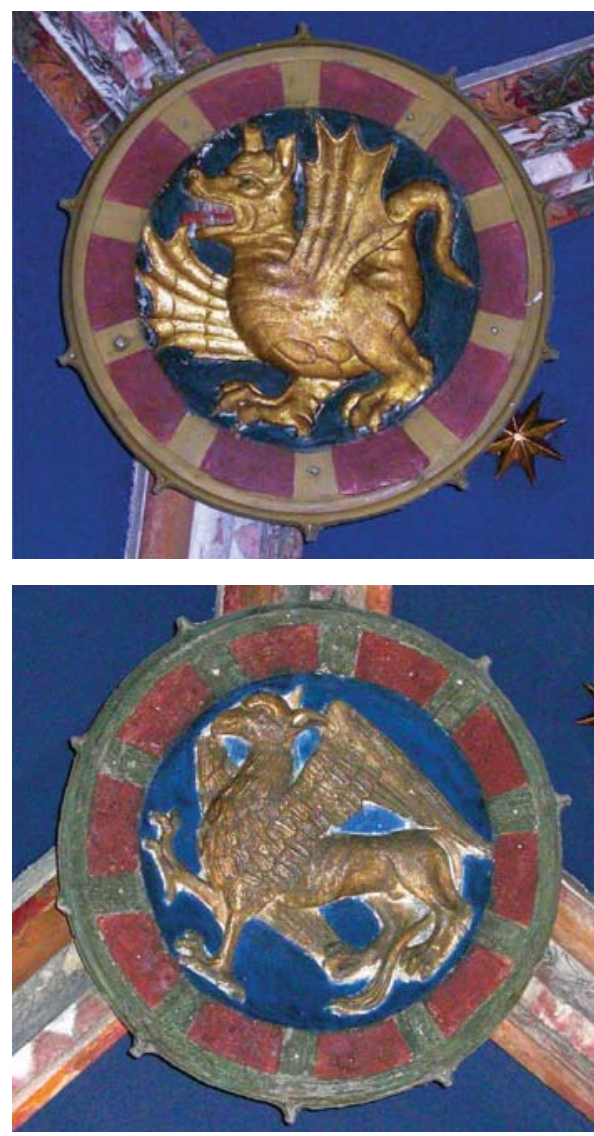

Fig. 14: a) Dragón. Clave de la bóveda de la Cámara estrellada (c. 1492). Casa del cordón. Vitoria (Álava); b) Grifo. Clave de la Bóveda de la Cámara estrellada (c. 1492). Casa del cordón. Vitoria (Álava). terrestre y divina-celeste) ${ }^{136}$, como explica Dante en la Divina comedia ${ }^{137}$.

Peter Armour ha advertido una poderosa teología política asociada a este animal que asumió el partido gibelino como representación del concepto de soberanía popular y elección de la realeza terrena bajo el poder de Dios; una idea asumida por la ideología política del primer Trastámara que -como hemos visto- apelaba a la comunidad como delegada de Dios para justificar su acceso al trono. Según la posiciones gibelinas de Dante, el grifo expresa en su biformidad la unión constitucional del monarca ideal y el pueblo, encarnando la recreación del paraíso en la tierra como utopía política donde el grifo acabaría representando al último emperador de la monarquía universal, el Cristo-Principe del Este y del Oeste que conducirá al triunfo final de la Cristiandad y luego consignará el poder terreno a Dios en la Jerusalén restaurada ${ }^{138}$

Sin adjudicar un origen gibelino al grifo Trastámara, no debemos menospreciar la simbología política que este animal pudo asumir en la heráldica hispana a mediados del siglo XIV ${ }^{139}$. Su temprana presencia en el retablo de Tobed sugiere la influencia de la corte aragonesa, concretamente el dragón de Pedro IV como modelo de animal prestigioso, del que se distinguía el grifo por su carácter híbrido que lo vincula

136 Véase la consideración de San Isidoro en sus Etimologías: "Cristo es león porque reina y tiene la fuerza; águila, porque, después de la resurrección, sube al cielo"; cfr. Jorge Luis BorgEs, Libro de los seres imaginarios, en ID., Obras completas, Madrid, 1979, pp. 639 y ss; Juan Eduardo Cirlot, Diccionario de símbolos, Madrid, 2003, p. 236; PÉrez RiojA, Diccionarios de símbolos y mitos, ob. cit., p. 229; MoNTELLS y Galán, Diccionario heráldico, ob. cit., p. 34; Peter Armour, Griffins, en Mythical Beasts, ed. John Cherry, Londres, 1995, pp. 93-94; Malaxecheverría Rodriguez (ed.), Bestiario medieval, ob. cit., p. 79.

137 El poeta alude a "la fiera / ch'è sola una persona in due nature", en el canto 32 del Purgatorio redactado hacia 1307-1314; cfr. Peter Armour, Dante's Griffin and the History of the World: A Study of the Earthly Paradise (Purgatorio, Cantos XXIX-XXXIII), Oxford, 1989.

138 Ibidem, pp. 277-278.

139 Sobre su presencia en Navarra y Aragón cfr. MenÉndez Pidal, Heráldica de la casa real, ob. cit., p. 288; véase también la explicación del grifo emblemático en PASTOUREAU, Traité d'héraldique, ob. cit., pp. $155-156$. 
al león real de Castilla y al águila de la tradición imperial castellano-leonesa' ${ }^{140}$. En este reino, el grifo adquirió una dimensión heroica alimentada por la literatura épica y las fuentes enciclopédicas que ubican su origen en Oriente ${ }^{141}$. En el Libro de Alexandre (s. XIII) cuatro grifos decoran el trono de Darío y dos ejemplares -"aves valientes"ayudan a Alejandro a ascender a los cielos "por veyer tod'el mundo, cómmo yazié o quál era" ${ }^{142}$. Son los compañeros del héroe en su ascenso a la gloria convirtiéndose ellos mismos en metáfora del poder. Hay que añadir a ello el valor profético cristiano que asume el grifo en la Gran conquista de Ultramar (c. 1293), al expulsar -en la visión de la esposa del conde Eustacio- a las "bestias malas" del templo de Jerusalén y el Santo Sepulcro, encarnando "uno de los más honrados hombres de la hueste, que escogerán los cristianos por rey, e le alzarán por señor de toda la tierra" para recuperar de la Ciudad Santa ${ }^{143}$.

El mensaje no podía ser más oportuno para impulsar el ascenso político de Enrique II, necesitado de legitimaciones mesiánicas que le permitieran superar el déficit de su bastardía. Este mesianismo sintonizaba con la propaganda trastámara que acusaba a Pedro I de simpatizar con herejes y judíos ${ }^{144}$, y más adelante tachará a los cismáticos portugueses por abandonar la causa aviñonense hacia $1382^{145}$. La presencia del grifo como cimera en el retablo de Tobed $^{146}$ (Fig. 3), constituye una de sus primeras apariciones, teniendo en cuenta la prioridad de este soporte sobre otras representaciones de la divisa ${ }^{147}$. Sus garras amenazantes podrían expresar la pugna por el reino de Castilla y León, representado en los manteletes del yelmo; las alas desplegadas anunciarían la victoria; y el color dorado identifican a la bestia con el rey, portador de este metal precioso símbolo de plenitud y gloria (Fig. 15). Más

${ }^{140}$ Así lo sugiere David Nogales Rincón en su artículo Un año en la corte de Enrique III de Castilla (1397-1398), que he podido consultar gracias su generosidad.

${ }^{141}$ La Semejança del mundo, libro geográfico-enciclopédico del primer tercio del siglo XIII lo hace oriundo de la India; cfr. Alan Deyermond, "Leones y tigres en la literatura medieval castellana", en Armando López Castro, y María Luzdivina Cuesta Torre (ed.), Actas del XI Congreso Internacional de la Asociación Hispánica de Literatura Medieval, vol. I, León, 2007, pp. 56-57.

${ }_{142}$ En este trasunto de la Ascensión de Cristo, los grifos aparecen como encarnación mitológica de los ángeles psicopompos que en algunos evangelios apócrifos conducen a Jesucristo hacia Cielo; sobre este pasaje cfr. Juan CASAS Rigall, Libro de Alexandre, Madrid, 2007, p. 684. El episodio es recordado años después por Gonzalo Martínez de Medina al referirse al héroe macedonio que "De aver todo el mundo a su obedençia, / fue buscar el çielo en gerfos bolando"; Dezir que fue fecho sobre la justiçia e pleitos e de la gran vanidad deste mundo; en Michael GerLi (ed.), Poesía cancioneril castellana, Madrid, 1994, p. 215.

${ }^{143}$ La gran conquista de Ultramar que mandó escribir el Rey Don Alfonso el Sabio, Biblioteca de autores españoles, vol. XLIV, Madrid, 1858, pp. 91-92 y 225.

${ }^{144}$ Cfr. Emilio Mitre Fernández, La Historiografía bajomedieval ante la revolución trastámara: propaganda política y moralismo, en Estudios de Historia Medieval en homenaje a Luis Suárez Fernández (V. A. Álvarez Palenzuela; M. Á. Ladero Quesada; J. Valdeón Baruque, coords.), Valladolid, 1991, pp. 333-347; Julio VAldeón BARUQue, La propaganda ideológica arma de combate de Enrique de Trastámara (1366-1369), "Historia. Instituciones. Documentos", 19 (1992), pp. 459-467.

${ }^{145}$ Rafael Sánchez Sesa, Santiago contra Sao Jorge: cisma, religión y propaganda en las guerras castellano-portuguesas de la Baja Edad Media, "Hispania Sacra", 56-114 (2004), pp. 447-464

${ }^{146}$ Las identificaciones anteriores como dragón o pantera deben desecharse ante un análisis detenido de la morfología del animal con su característico pico de águila.

${ }^{147}$ Así sucede con el dragón de Pedro IV analizado más arriba. 


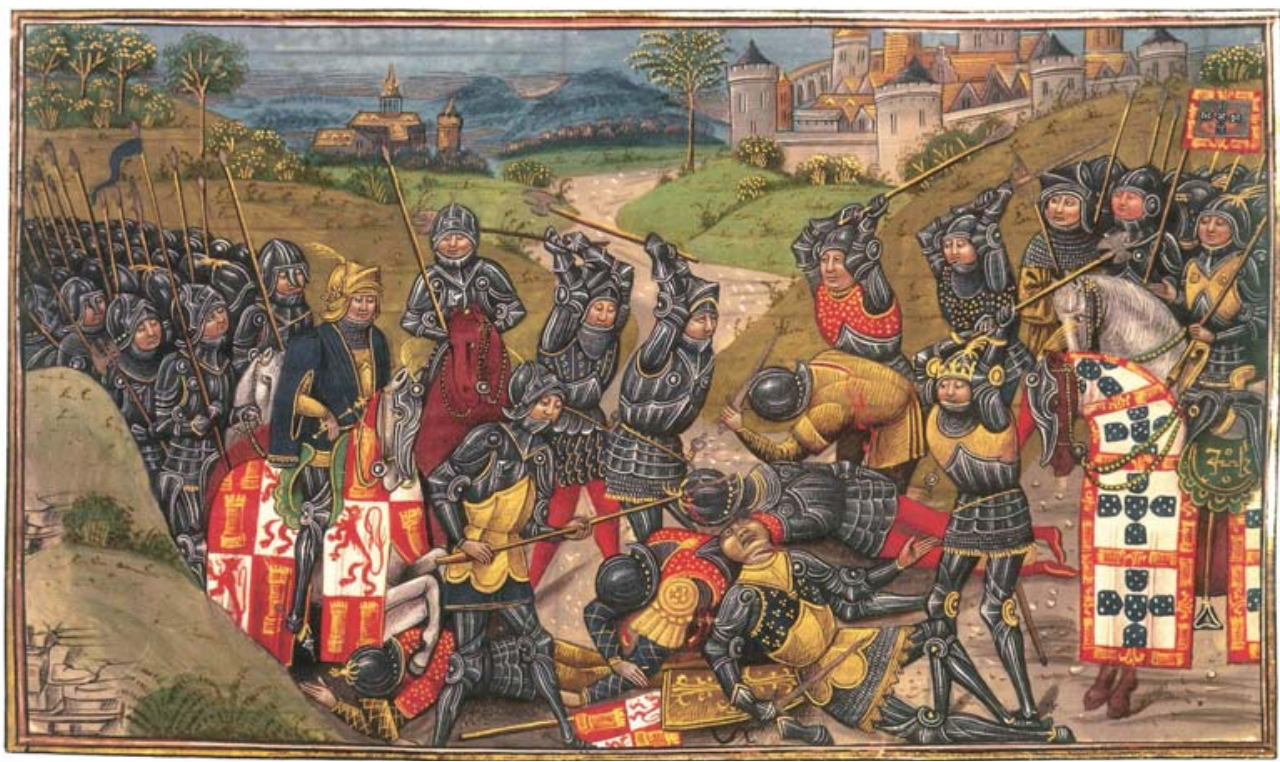

Fig. 15: Juan I con armadura dorada, montado sobre un caballo con gualdrapas de Castilla y León. Entre las enseñas abatidas se reconocen las armas reales y la inicial regia "I" de "Ioannes". La batalla de Aljubarrota, miniatura de Jean de Wavrin, Chonique d'Angleterre, Brujas, fines del siglo XV, The British Library (Londres), Royal, 14 E.IV, f. 204..

adelante su sucesor, Juan I, usó este metal en las barras que representaban el reino castellano -junto a las de plata de Portugal- en uno de los estandartes capturados en Aljubarrota ${ }^{148}$; y en la inicial "I" [de "Ioannes"] dorada sobre fondo pardo que figura en una enseña dibujada por Jean de Wavrin en una miniatura de la batalla, junto al monarca castellano vestido con una armadura igualmente dorada (Fig. 13) ${ }^{149}$.

El grifo que ostenta Enrique II también se reproduce en la cimera de su primogénito, representado de rodillas junto al rey, poniendo de manifiesto su carácter dinástico. Durante el reinado de Juan I, vuelve a aparecer en el armorial de Gelre (1370-1395) adornando la cimera del yelmo del rey de España (die coninc van Spaengen) (Fig.

${ }^{148}$ Fernández de CóRdova Miralles, Los emblemas de la conquista, ob. cit., pp. 237 y ss.

${ }^{149}$ La batalla de Aljubarrota, miniatura de Jean de Wavrin, Chonique d'Angleterre, Brujas, fines del siglo XV; The British Library (Londres), Royal, 14 E.IV, f. 204; una reproducción en VALDEÓN BARUQUE, La dinastía de los Trastámara, ob. cit., p. 58. El amplio uso del oro en el vestuario de Juan I se documenta en las cuentas reales recogidas por MARTínez MARTínez, La imagen del rey, ob. cit., pp. 277-287. Posteriormente otras divisas reales tendrán el mismo color dorado, como el cordón de San Francisco de Enrique III, la piña de Catalina de Lancaster y el collar de la Escama de Juan II; cfr. FERnÁNDEZ DE CórDOVA, Las divisas del rey: escamas y ristres, ob. cit., pp. 30-31; ID., El cordón y la piña, ob. cit. Sobre la importancia del dorado en la simbólica regia castellana cfr. José Damián GonZÁlez ARCE, El color como atributo simbólico del poder (Castilla en la baja Edad Media), "Cuadernos de arte e iconografía", 6/11 (1993), pp. 103-108. 
$16)^{150}$, como debía suceder en el inconcluso armorial de Bellenville (c. 1380) ${ }^{151}$. El segundo Trastámara cedió esta cimera a sus vástagos, comenzando por su primogénito Enrique III que en 1398 disponía de un anillo sigilar con las armas reales timbradas por un yelmo con "una cabeça de grifo" por cimera ${ }^{152}$. El infante Fernando [de Antequera] también recibió de su padre en 1390 la cimera del grifo, incorporándola -como su hermano- al yelmo que timbra sus armas, doce años antes de que se convirtiera en animal emblemático de su orden de la Jarra y el Grifo, representando la fortaleza en el amor a Dios y en las "obras de la Cavalleria [...] según el costumbre e antiguo aprobado por los Reyes de Castilla donde yo vengo"153.

Como es sabido, la emblemática de la orden fue uno de los elementos vertebradores de la propaganda del conquistador de Antequera en su acceso al trono aragonés en $1412^{154}$. El grifo adquirió entonces una gran espectacularidad exhibiéndose en estandartes o en forma de entremés, como sucedió en Zaragoza el día de la coronación $(1414)^{155}$, o en las justas de Valladolid (1428) que organizaron los infantes de Aragón para eclipsar a Álvaro de Luna ${ }^{156}$. Otros miembros de la familia real también lo usaron: el infante Enrique lo ostentó en su sello entre dos caballos acuáticos (Fig. 17) ${ }^{157}$;

${ }^{150}$ Bibliothèque Royale de Bruxelles, Ms. 15652-56, f. 60v; cfr. MenÉndez PidAl, Heráldica de la casa real, ob. cit., p. 286.

151 Se trata del escudo del rey de Castilla y León, que se representa inclinado con el cuartelado de castillos y leones (apenas insinuados) y el espacio reservado al yelmo con cimera sin completar; Bibliothèque Nationale de France (París), Ms. fr. 5320, f. 5r; Léon JÉQUIER, L'armorial Bellenville, París, 1983, pp. 18, 36, 38, 58 y 248 (representación en blanco y negro).

${ }^{152}$ La presencia del grifo dinástico apoya la posibilidad de que se trate del "sello secreto y personalísimo del rey" que no custodiaba el canciller sino el monarca o alguno de sus oficiales más íntimos; Nogales Rincón, Un año en la corte de Enrique III de Castilla, ob. cit.

153 "Assi como el Grifo es fuerte sobre todos los animales brutos, que assi todos aquellos de la dicha devisa deven ser fuertes e firmes en el amor de Dios, de la Virgen Santa Maria, e por lo semejante en las obras de la Cavalleria, e aun porque los fijos primogenitos de los reyes, principes e senyores, por la primogenitura, segun el costumbre e antiguo aprobado por los Reyes de Castilla donde yo vengo"; Ordenanças de la cavalleria de la Jarra, en Diego José Dormer, Discursos varios de historia con muchas escrituras reales antiguas y notas a algunas dellas, Zaragoza, 1683, pp. 189-190.

${ }^{154}$ Cfr. Lorenzo Tadeo Villanueva, La Orden Española de Caballeria de la Jarra, "Boletín de la Real Academia de la Historia", 75 (1919), pp. 68-77; Torres FonTes, Don Fernando de Antequera y la romántica caballeresca, ob. cit., pp. 83-120; Angus MACKAY, Don Fernando de Antequera y la Virgen María, en Homenaje a Juan Torres Fontes, vol. II, Murcia, 1987, pp. 949-956; Franz-Heinz vON Hye, Testimonios sobre las Ordenes de Caballería españolas en Austria y estados vecinos, "En la España medieval", 16 (1993), pp. 169-188; y los datos aportados por Roser SALICRú I LluCH, Caballeros cristianos en el Occidente europeo e islámico, en "Das kommt mir spanisch". Eigenes und Fremdes in den deutsch-spanischen Beziehungen des spaten Mittelalters (K. HERBERs; N. JASPERT, eds.), Münster, 2004, pp. 217-289.

${ }^{155}$ Roser SAlicrú I LLuch, La coronació de Ferran d'Antequera: l'organització i els preparatius de la festa, "Anuario de Estudios Medievales", 25-2 (1995), pp. 699-759; MASsiP BonET, La monarquía en escena, ob. cit., pp. 54-56.

${ }^{156}$ El infante Enrique levantó en estas justas un fantasmagórico castillo y un pilar sobre el que se alzaba "un grifo dorado, el qual tenía en los brazos un estandarte muy grande de blanco e colorado", que debía representar la insignia de la orden; cfr. Francisco Rico, Unas coplas de Jorge Manrique y las fiestas de Valladolid en 1428, "Anuario de Estudios Medievales", 2 (1965), pp. 525-534.

157 Nos referimos al gifo que el infante Enrique usa como cimera del yelmo que timbra sus armas entre dos tritones- en su sello de 1439; véase el dibujo de Salazar y Castro conservado en Real Academia 


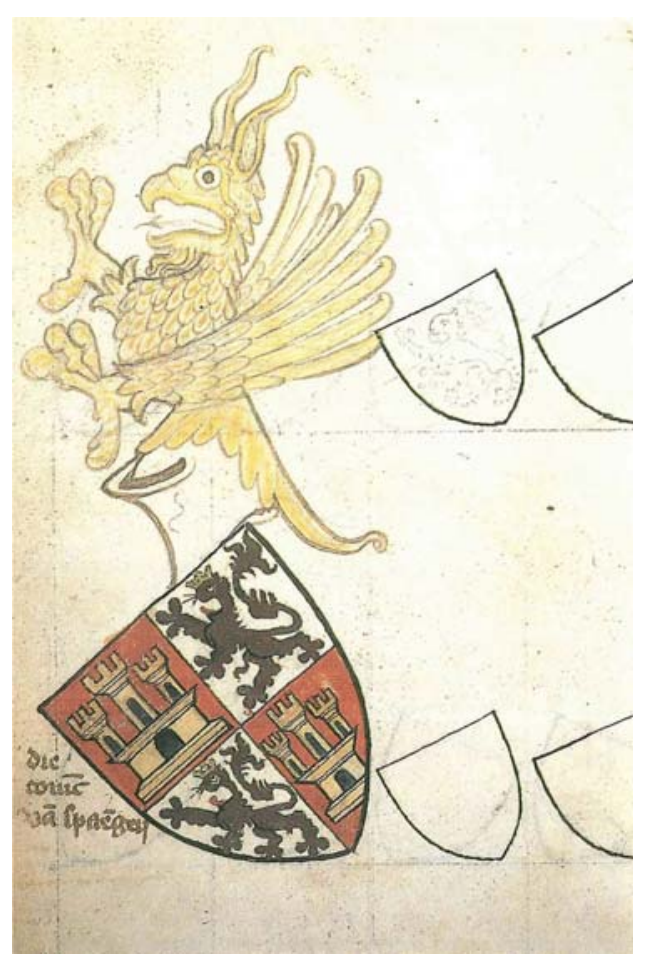

Fig. 16: Escudo timbrado con la cimera del grifo, perteneciente al rey de Castilla (Juan I). Armorial de Gelre (c. 1370-1395). Fotografía: Faustino Menéndez Pidal.

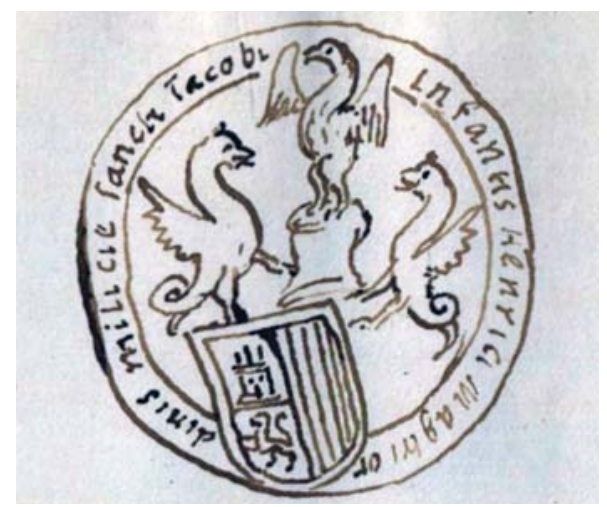

Fig. 17: Sello del infante Enrique, hijo de Fernando de Antequera, con el grifo como cimera del yelmo que timbra sus armas (1439). Real Academia de la Historia (Madrid), Colección Salazar y Castro, K-36, f. 80r. Dibujo: Luis de Salazar y Castro.

Catalina de Lancaster como tenante de su divisa personal, la piña dorada (Fig. 18) ${ }^{158}$; y su recuerdo perduraba a fines del siglo XV cuando se incluyó entre las divisas reales representadas en la bóveda estrellada de la Casa del Cordón (Vitoria) (Fig. 14b) ${ }^{159}$.

\subsection{EL HALCÓN EXPLAYADO DE LA CONQUISTA}

Junto a la simbólica heredada, Juan I adoptó sus propias divisas personales tomadas del repertorio faunístico. Entre éstas se encuentra el halcón en campo verde

${ }^{158}$ Así sucede en la taza dorada adornada con follajes "de que salen unas a manera de pinas doradas con un grifo dorado en medio"; inventario datado entre 1424 y 1426 y publicado por José Manuel NiETO Soria, El tesoro de Doña Leonor, esposa de Fernando I de Aragón en el monasterio de Guadalupe, "Acta historica et archaeologica mediaevalia", 18 (1997), p. 56; o en la hermosa labra de la iglesia del monasterio de Santa María la Real de Nieva (Segovia), donde los grifos también se repiten en el friso de la puerta de la iglesia y en un capitel de la capilla mayor sosteniendo castillos y timbrando las armas de Castilla y León; cfr. Alfonso de Ceballos Escalera Gila, Emblemas heráldicos en el Monasterio dominicano de Santa María la Real de Nieva, y en la Villa, "Cuadernos de Ayala", 37 (2009), pp. 8-11; FERnÁNDEZ de CóRdova, El cordón y la piña, ob. cit.

159 Véase la nota anterior dedicada a esta bóveda recientemente descubierta y restaurada. 


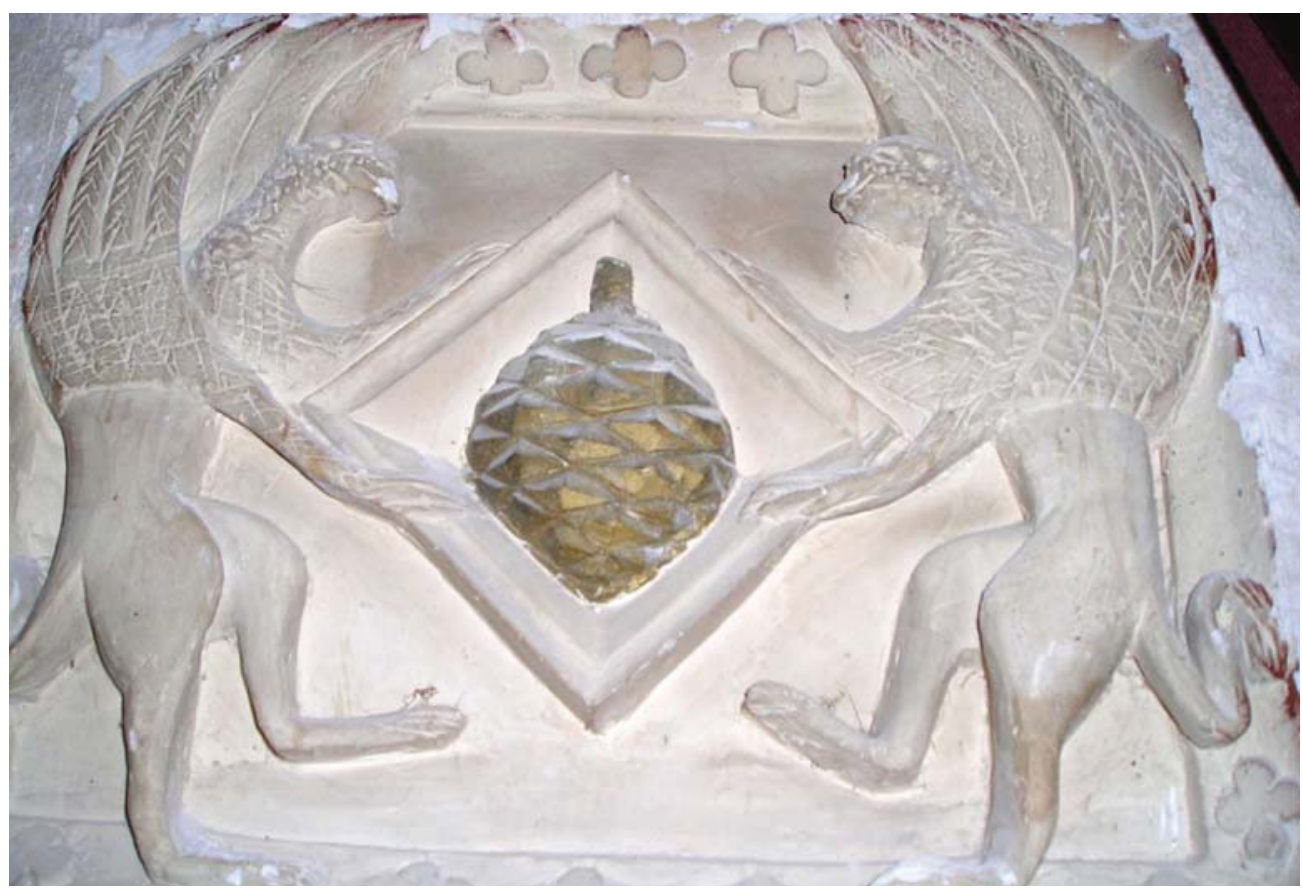

Fig. 18: Piña dorada en losanje sostenida por dos grifos. Monasterio de Santa María Real de Nieva (Segovia). Capilla mayor.

que figuraba en una de las enseñas capturadas en Aljubarrota y que el monarca debió simultanear con las otros emblemas dinásticos como hacía su homónimo Juan I de Aragón (1387-1396) al conservar el dragón de Pedro IV y adoptar el leopardo como divisa personal desde $1377^{160}$. El halcón castellano aparecía representado con las alas extendidas y sosteniendo con sus garras un lema en francés ("un bom mote", según Fernão Lopes) que decía "En boõ ponto", es decir, En buen punto (en buena posición, en el momento oportuno), o En bon point en su redacción francesa ${ }^{161}$. De confirmarse esta atribución, estaríamos ante la primera divisa regia castellana dotada de un texto escrito (mote o lema) que, además, sugiere la influencia francesa que

de la Historia (Madrid), Colección Salazar y Castro, K-36, f. 80r.

${ }_{160}$ Riera I SANS, Els heralds i les divises del rei Martí, ob. cit., p. 45; sobre la emblemática de Juan I ver también Alberto Montaner Frutos, Testimonios heráldicos, en La Aljafería (B. Cabañero SubizA, et alt., coords.), vol. II, Zaragoza, 1998, pp. 133-135.

${ }^{161} \mathrm{El}$ cronista portugués se refiere a "dous blações del Rey, isso mesmo de sua divisa huũ deles, cujo campo hera verde e em meo huũ falcão que nas maoõs tinnha huũ rotulo com huũ mote, que ẽ limguoagẽ framces dizia: Em boõ ponto"; Fernão Lopes, Crónica de D. João I, ed. A. Braamcamp Freire, Oporto, 1949, p. 123; también ID., Chronica de El-Rei D. João, ob. cit., vol. IV, p. 191; el texto portugués ha sido transcrito En bom posto por Crispín Ximénez DE SANDOval, Batalla de Aljubarrota. Monografía histórica y estudio crítico-militar, Madrid, 1872, p. 275, de donde lo toman César Fernández Duro, Disquisiciones náuticas. Conformación, adorno y armamento de naves antiguas, Madrid, 1876, pp. 289-290; y MenÉndez Pidal, Heráldica de la casa real, ob. cit., p. 289. 
también se documenta en la emblemática de Juan I de Aragón ${ }^{162}$ y en la de João I de Portugal $^{163}$. En el caso Trastámara estaba aún más justificada al haber firmado con los Valois una de las alianzas más estables del Occidente europeo ${ }^{164}$, impulsando transferencias como la adopción por Juan I de los cargos de condestable y mariscal ${ }^{165}$, con mando sobre los oficiales encargados de las enseñas como el alférez mayor del pendón real ${ }^{166}$, o el portador del estandarte del rey de Francia documentado en la

162 Juan I de Aragón -casado sucesivamente con tres princesas francesas-se interesó en sus tiempos de infante (1350-1387) por el carner (carnero) que "tots los grans senyors en França porten en lo arçó de la sela", aludiendo probablemente al vellocino de Oro de la materia de Troya, y en 1387-1389 intercambió su divisa del águila dorada -tomada de las armas de Sicilia-y el ceñidor (cinyell) con el duque de Berry y Carlos de VI Francia. Finalmente la influencia gala también se advierte en el mote francés Sperança ne faudra que hizo grabar en su cámara en 1395; Daniel Girona I LlaGostera, Itinerari de l'infant en Joan: primogènit del rei en Pere III: 1350-1387, Valencia, 1923, doc. 637; comentado por Francesca EsPañol Bertrán, Artistas y obras entre la Corona de Aragón y el reino de Francia, en El intercambio artístico entre los reinos hispanos, ob. cit., p. 269; también RocA, Johan I d'Aragó, ob. cit., p. 429. Se sigue la pista al collar de vainas de retama (cosse de genêt) que Carlos VI debió enviar al príncipe aragonés, una de cuyas joyas acabó adornando la custodia de la catedral de Barcelona, en Joan Domenge Mesquida, "Joya en forma de vaina de retama", en Cataluña 1400. El gótico internacional (R. Cornudella, ed.), Barcelona, 2012, p. 118. Respecto a la posible influencia de la emblemática aragonesa en la castellana baste considerar la petición de Juan I a su homónimo aragonés en 1383 de un ejemplar de las Ordinacions de Pedro I (Bonifacio Palacios Martín, Sobre la redacción y difusión de las "Ordinacions" de Pedro IV de Aragón y sus primeros códices, "Anuario de estudios medievales", 25-2 (1995), p. 666), o los juglares -tantas veces adornadas con las divisas reales- enviados por el monarca aragonés para los desposorios de Enrique (III) y Catalina de Lancaster en 1388; Peter Edward RusselL, The English Intervention in Spain and Portugal in the Time of Edward III and Richard II, Oxford, 1955, pp. 508-509.

${ }^{163}$ En la corte portuguesa el francés se impuso como lengua de las divisas que irrumpen durante el reinado de João I (1385-1433), tal vez por influencia de su aliado Juan de Gante y su hija Felipa de Lancaster esposa del portugués. Éste usó como lema Par bien, que se completaba con la divisa de su esposa Felipa Il me plait; más adelante el infante Pedro, duque de Coimbra escogerá Desir, el infante don Henrique (1394-1460), duque de Vizeu Talent de bien faire (talant de bië faire), y el infante don João, duque de Guarda, Je ai bien raison; cfr. Henrique Nuno Avelar, y Luís Ferros, As empresas dos Príncipes da Casa de Avis, en $17^{a}$ Exposição de Arte, Ciência e cultura - Os descobrimentos portugueses e a Europa do Renascimento, Lisboa, 1983, pp. 227-245; Manuel Artur NorTon, Portuguese badges, "Family History, Canterbury, The Institute of Heraldic and Genealogical Studies", 8 (48). Dec. New Series, 24 (1974), pp. 159-169; Isabel Paço D’Arcos, O pilriteiro, empresa de D. João I, "Tabardo", 3 (2006), pp. 57-66; Miguel Metelo de SeIXAs, De Vermelho, um Leão de Ouro... Relações entre a heráldica de familia e a heráldica do Exército Português, Lisboa, 2007; véase también su excelente elenco bibliográfico ID., Bibliografia de heráldica medieval portuguesa, en Estudos de heráldica medieval (M. M. de SEIXAs; M. de L. Rosa, coords.), Lisboa, 2012, pp. 572-573.

${ }^{164}$ Luis Vicente Díaz Martín, Los inicios de la política internacional de Castilla (1360-1410), en Realidad e imágenes del poder. España a fines de la Edad Media (A. RucQuoI, coord.), Valladolid, 1988, pp. 57-87.

${ }^{165}$ Cfr. David Torres SAnz, La administración central castellana en la Baja Edad Media, Valladolid, 1982, pp. 247-256; Juan Torres Fontes, Los condestables de Castilla en la Edad Media, "Anuario de Historia del Derecho Español”, 41 (1971), pp. 57-112; y nuestra aportación más general Álvaro Fernández de Córdova Miralles, La corte de Isabel I. Ritos y ceremonias de una reina (1474-1504), Madrid, 2002, pp. 17-40 y 212-220.

166 Tomamos el texto del tardío nombramiento como condestable de Miguel Lucas de Iranzo, donde se refieren las atribuciones del condestable; Hechos del Condestable Don Miguel Lucas de Iranzo (Crónica del siglo XV), ed. Juan de Mata Carriazo, Madrid, 1940, cap. I, pp. 10-12. 
Cámara regia hacia $1380^{167}$; si no era el propio condestable quien se hacía cargo de la enseña de la divisa ${ }^{168}$.

Esta asociación del condestable y la emblemática regia podría explicar que su titular Ruy López Dávalos (c. 1360-1428) se identificara con el "gentil falcon" en el poema de Álvarez de Villasandino exaltando sus hazañas contra el portugués (1396) ${ }^{169}$. El halcón era el ave preferida de la aristocracia medieval que, paradójicamente, había quedado excluido del bestiario heráldico ${ }^{170}$. Esta ausencia explica su difusión en el terreno de las divisas como sustituto del águila, animal propio de las armerías. Se documenta a fines del siglo XIV en la corte saboyana de Amadeo VII y entre los Visconti, que representaban el halcón con un mote semejante al castellano: Adeso el tempo, aludiendo a la rapidez con que el halcón se abate sobre su presa ${ }^{171}$. En la península Ibérica se le detecta en la novela caballeresca Curial e Güelfa (1435-1468), figurando en el estandarte y el pabellón del héroe ("cavaller del falcó encapellat") durante el torneo de Melún ${ }^{172}$.

En la literatura castellana el halcón representa el ave de cetrería por antonomasia, siendo la especie más citada del Cancionero de Baena por su destreza, astucia y nobleza ${ }^{173}$. Los tratadistas lo tenían por un "ave real" que simbolizaba la victoria ${ }^{174}$,

${ }^{167}$ SuÁrez FernÁndez, Historia del reinado de Juan I, ob. cit., p. 293. El interés por la emblemática de los Valois también se detecta en la crónica de Pedro López de Ayala, al aludir al "ciervo-volante" o ciervo alado (cerf volant) grabado en la tienda de Carlos VI durante sus vistas con Ricardo II de Inglaterra en Ardres (1396); LóPez DE Ayala, Crónica de Enrique III, ob. cit., p. 244. La referencia emblemática también figura en la documentación que debió emplear el cronista; cfr. Biblioteca Nacional de España (Madrid) [a partir de ahora BNE], Ms. Res. 27, ff. 51r-53. Años después Gutierre Díez de Gamés recordaba con menos precisión el "collar a fazión de vaynas de arvejas" [¿el collar de la vaina de retama?] que -según el biógrafo de Pero Niño- adoptó Carlos VI tras la batalla de Roosebeke (1382); DíEZ DE GAMÉs, El victorial, ob. cit., cap. 81, p. 571.

${ }^{168}$ Es posible que la divisa se grabara en el estandarte que recibía de manos del rey y debía ser "un standal de la seña de las armas del rey por señal de acabdillamiento quel otorga", como prescriben las Partidas para la investidura de almirante que sirvió de modelo a Juan I para la de condestable, como comentamos más arriba; cfr. Ceballos-Escalera Gila, Norma y ceremonia de los Almirante, ob. cit., pp. 76-95.

${ }^{169}$ Así lo hace el poeta Álvarez de Villasandino al relatar la toma de Benavente (1386) y las villas de Miranda y Penamacor (1396); Cancionero de Juan Alfonso de Baena, ob. cit., pp. 102 y ss; sobre el personaje cfr. Óscar Perea Rodríguez, El Cancionero de Baena como fuente historiográfica de la Baja Edad Media castellana: el ejemplo de Ruy López Dávalos, en Cancioneros en Baena. Actas del II Congreso Internacional Cancionero de Baena. In memoriam Manuel Alvar (J. L. SERRAno ReYes, ed.), vol. I, Baena, 2003, pp. 293-334. El condestable volvió a desempeñar su faceta representativa en el poema de Villasandino dedicado a Juan II en fechas próximas a su acceso a la mayoría de edad, donde desfiló "el grant girifalte con reçia soltura / vaya adelante bien aperçebido"; Cancionero de Juan Alfonso de Baena, ob. cit., p. 225. Sobre su ejercicio del cargo cfr. TORRES Fontes, Los condestables de Castilla, ob. cit., pp. 67-77.

${ }^{170}$ Pastoureau, L'art héraldique, ob. cit., p. 107.

${ }^{171}$ Навцот, La devise, mise en signe du prince, ob. cit., pp. 66-67.

172 Regula LangBehn-Rolmand, Curial e Güelfa: los hechos caballerescos y la unidad constructiva de la novela, en Homenaje al Instituto de Filología y Literaturas Hispánicas "Dr. Amado Alonso" en su cincuentenario 1923-1973, Buenos Aires, 1975, pp. 159 y 167.

${ }_{173}$ Montero Curiel, y Montero Curiel, El léxico animal, ob. cit., pp. 241-247.

${ }_{174}$ Guy de Tervarent, Atributos y símbolos en el arte profano. Diccionario de un lenguaje perdido, Barcelona, 2002, pp. 284-286. 
asumiendo valores morales superiores a los del águila, pues "es aue piadosa, ca el pollo que el águila desecha, éste lo rescibe e cría, e es tan fuerte que vence el águila"175. $\mathrm{Su}$ contrapunto era el milano, como señala la Glosa castellana al Regimiento de Príncipes, a quien supera en nobleza de corazón, "ca el milano tan apuesto parece como el falcón, mas en la presión paresce cual es, que se echa sobre la vil cosa así como sobre las tripas, más el falcón sigue la garza fasta el cielo"176. Se le consideraba por ello dux de las aves "como el león es caudillo de los animales", estableciendo sugestivas analogías con la jerarquía del poder, especialmente el halcón neblí, a quien López de Ayala considera "señyor e e príncipe de las aves de la caça [...] ca toda la nobleza e bien del falcón altanero es que sea más alto que pudieres"177.

Gracias a su prestigio, la rapaz dejó su impronta en algunos cargos cortesanos relacionados con la cetrería, como el halconero que empieza a documentarse con Alfonso IX de León, y en tiempos de Pedro I recibe el nombre de halconero mayor ${ }^{178}$. Con Juan I, el excepcional desarrollo de este arte llevó a Pedro López de Ayala a componer su Libro de la caza de las aves durante su cautiverio portugués tras la derrota de Aljubarrota ${ }^{179}$. Eran años en que la fama de las aves castellanas se había extendido a Navarra donde Carlos III el Noble desembolsó en 1383 y 1384 ciertas cantidades de dinero por ejemplares remitidos por Juan $\mathrm{I}^{180}$.

Auxiliar en su entrenamiento cinegético, el halcón no tardó en incorporarse a la imagen del príncipe, quien debía portar "en la izquierda un azor o halcón”, según don Juan Manuel ${ }^{181}$. A nivel profético, también se identificó con la descendencia regia anunciada por Merlín. Una profecía de la Demanda de sancto grial augura el nacimiento de un hijo del rey león de España que "será llamado falcón bolador

175 "Es aue real llamada falcón, de poca carne, según su cuerpo, y de mucha pluma, donde nasce su mucho volar. Tiene pecho y vñas muy agudas, y fiere más la ralea con el pecho que con el pico e vñas. Tiene condición que si no lleua la presa del primero o segundo golpe, casi él mesmo se da la penitencia, que si es doméstico, como de vergüenza, apenas buelue ala mano, e si es brauo, de desdeño, ayuna. Es aue piadosa, ca el pollo que el águila desecha, éste lo rescibe e cría, e es tan fuerte que vence el águila. No toca cuerpo muerto ni carne podrida, avnque muera de fambre. Algunos creen que es el que el vulgo llama giriphalte. Otros, menos cierto, creen ser gripho [...]. Dux est forum, id est de páxaros o delas aues, como el león es caudillo de los animales"; Rodrigo Fernández DE SANTAELla, Vocabularium seu lexicon ecclesiasticum latino-hispanicum (1499); en Nuevo Tesoro Lexicográfico, ob. cit., vol. VI, p. 5333.

176 Juan García de Castrojeriz, Glosa castellana al Regimiento de Príncipes de Egidio Romano, ed. J. Beneyto, vol. II, Madrid, 1947, p. 324.

177 Pedro López de Ayala, Libro de la caça de las aves: el MS 16.392 (British Library, Londres), ed. John G. Cummins, Londres, 1986, p. 91.

178 Su titular era Juan Jofré Tenorio, documentado en el oficio desde 1353; cfr. SALAZAR Y ACHA, La Casa del Rey de Castilla y León, ob. cit., pp. 320-322.

179 Además de la edición de John G. Cummins, véase el análisis de Gómez Redondo, Historia de la prosa medieval, ob. cit., vol. II, pp. 2036-2049.

${ }^{180}$ Cfr. Cañas Gálvez, La Casa de Juan I de Castilla, ob. cit., p. 168.

181 "Cuando salga de caza debe llevar en la mano derecha una lanza, u otra vara y en la izquierda un azor o halcón. Este ejercicio le acostumbrará los brazos: con el derecho será hábil para herir y el izquierdo será útil para llevar el escudo como medio de defensa"; Don JuAn Manuel, Libro de los estados, en ID., Obras completas, ed. J. M. Blecua, Madrid, 1982-1983, cap. LXVII, p. 325. 

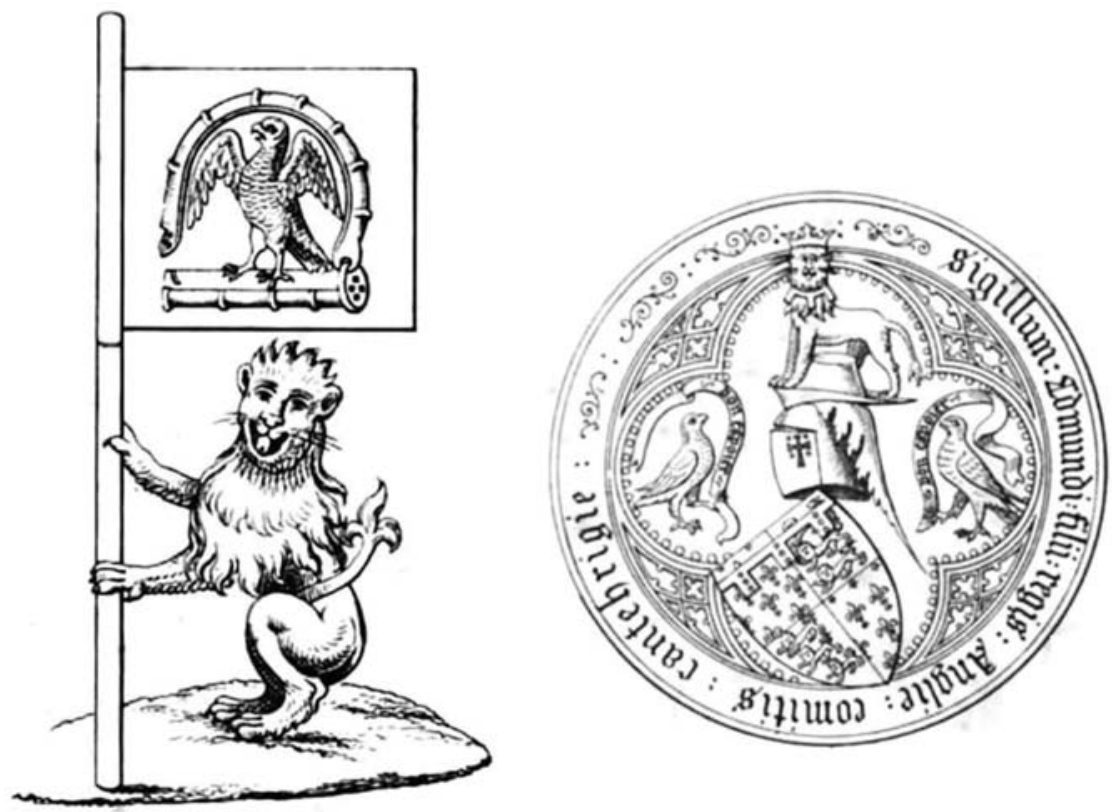

Fig. 19: a) Badge del duque de York en el Manuscrito Digby n. 82. Siglo XVI; b) Sello de Edmundo de Langley, I duque de York, flanqueado por dos halcones que sostienen el mote "Bon espoier" (bonne espoir o "buena esperanza"). Posterior a 1362; Grabado: James R. Planché.

de la gran ventura [...] y éste aurá cinco reynados en la isla de Asia" ${ }^{182}$; presagio de conquistas que el segundo Trastámara pudo proyectar sobre sus aspiraciones portuguesas. Un siglo más tarde, el profetismo falconiano volvió a proyectarse sobre Fernando de Aragón durante su enfrentamiento con Alfonso V de Portugal (1476), como se observa en el episodio de Cubillas, poco antes de la batalla de Toro, donde los partidarios del portugués atraparon un halcón del futuro rey Católico; hecho que fue interpretado como un presagio de la inminente caída de la fortaleza en manos de Fernando, identificado como nuevo rey-halcón ${ }^{183}$.

Desde el punto de vista emblemático, la divisa de Juan I pudo inspirarse en los badges de los descendientes de Eduardo III de Inglaterra (1327-1377), que lo usaba al menos desde $1359^{184}$. Curiosamente los hermanos Juan de Gante y Edmundo de

182 "El sabio Merlin dixo que este rey león aura otro fijo en la onça del ala. Y este nacerá en la fumera mayor. Y este será llamado falcon bolador de la gran ventura. Y este bolara sobre la gran fumera mayor; y este aura cinco reynados en la ysla de Asia a su mandar. E su boz sonara y el su gemido espantable"; Bonilla y SAN Martín (ed.) Libros de caballerías, ob. cit., vol. I, p. 161.

183 Alonso de Palencia, Crónica de Enrique IV, vol. II, Madrid, 1973, p. 321. Pocos años después, Gómez Manrique atribuyó al rey Fernando las virtudes y nobleza del ejemplar que éste le prestara; véase su poema dedicado al rey don Fernando nuestro señor, porque no le queria dar un alcon que le auia mandado hasta que le hiziese unas trouas; en Cancionero de poesías varias (Manuscrito $n^{\circ} 617$ de la Biblioteca Real de Madrid) (J. J. Labrador; C. Angel Zorita; R. A. DiFranco, eds.), Madrid, 1986, pp. 44-45.

184 Así parece consignarlo Foissart al aludir a un oficial de armas con este título que servía a Eduardo III en 1359; cfr. James R. Planché, On the Badges of the House of York, "Journal of the British 
Langley, primer duque de York, adoptaron unos halcones con candados como divisa en fechas muy próximas a sus respectivos matrimonios con las hijas de Pedro I de Castilla, Constanza e Isabel, asociando quizá los valores del candado -adhesión y decisión- a sus aspiraciones al trono castellano ${ }^{185}$. La combinación halcón-candado no se halla, sin embargo, en el sello del duque de York posterior a 1362, cuyos halcones sostienen entre sus garras el mote "Bon espoier" (bonne espoir o buena esperanza), que heredaron sus descendientes Ricardo de York (1411-1460) y su hijo, el futuro rey Eduardo IV de Inglaterra (1442-1483) (Fig. 19 a y b).

Juan I de Castilla debió conocer el halcón blanco en campo rojo que portaban las tropas inglesas de Ricardo II (1367-1400) -nieto de Eduardo III y sobrino de Juan de Gante y Edmundo de Langley- en la campaña de Lisboa de 1382, emprendida en auxilio de Fernando de Portugal ${ }^{186}$. A orillas del río Gaya, las tropas castellanas pudieron contemplar el halcón inglés que la población autóctona hizo grabar en diversos soportes para librarse de las violencias de sus propios aliados que sólo respetaban los lugares donde ondeaba su divisa ${ }^{187}$. En un gesto de rivalidad mimética, Juan I pudo apelar después al temor suscitado por esta divisa cuando desplegó su propio halcón frente al adversario portugués, sustituyendo el color rojo por el verde -símbolo de vigor y fortuna ${ }^{188}$ - e introduciendo el lema francés que anunciaba la inminente victoria.

Sin embargo lo que caracteriza a la divisa castellana es el fondo verde, y no el rojo. Como ha mostrado Pastoureau, la simbólica del verde se hallaba entonces en plena revalorización, abandonando su antigua asociación al desorden o la locura,

Archaeological Association”, 20 (1864), pp. 21-22.

185 Ibidem, pp. 22-23.

${ }^{186}$ La divisa de Ricardo II -sobre fondo verde en vez de rojo- también se documenta en las justas de Windsor de 1399, donde sus caballeros iban vestidos de verde con un halcón blanco; Froissart, Chroniques, ob. cit., vol. XVI, p. 151; cfr. НавLот, La devise, mise en signe du prince, ob. cit., pp. 208 y 446; sobre el fallido cerco castellano de Lisboa y los contactos con las tropas inglesas en el verano de 1382 cfr. SuÁrez Fernández, Historia del reinado de Juan I, ob. cit., vol. I, pp. 114-115. Por su exclusividad, el halcón blanco era objeto de prestigiosos regalos, como los dos ejemplares que la ciudad de Tarragona regaló a Fernando el Católico, y éste reenvió a Luis XII de Francia el 22 de julio de 1507; Marino SANUdo, Diarii, vol. VII, Venecia, 1879-1903, col. 137.

187 "Que cumpre dizer mais, em tanta pressa e sujeição foram postos os da cidade e seu termo, havendo d'elles medo como de seus grandes inimigos, que o conde [de Cambrix] ordenou, para guarda das quintas e casais, que cada um tivesse senhos pendões de sua divisa, que era um falcão branco em campo vermelho; e a quinta e casal onde os ingleses não achavam aquelle pendão logo era roubada de quanto aí havia. E quantas bestas vinham pera a cidade, assim das quintas como dos casais e montes de redor, para venderem suas cousas, cada um havia de trazer um pendão daquelles, que custava certa cousa, para lhe não fazerem mal"; Fernão LoPEs, Crônicas de D. Pedro e D. Fernando, París-Lisboa, 1921-1922, pp. 206-207.

${ }^{188}$ En fechas próximas a su coronación en 1378, Juan I usó esté color en prendas especialmente lujosas que podían adornarse con signos emblemáticos, como los paños de seda, y los procedentes de Montevilliers o de Malinas que se usaron probablemente para confeccionar el manto para la sobrecama del rey; cfr. Martínez Martínez, La imagen del rey a través de la indumentaria, ob. cit., pp. 282 y 285; sobre los valores del verde cfr. Michel Pastoureau, Les couleurs médiévales: systèmes de valeurs et modes de sensibilité, en Figures et couleurs. Étude sur la symbolique et la sensibilicé medievales, París, 1986, p. 40; ID., Diccionario de los colores, Barcelona, 2009, pp. 291-294; Juan CASAs Rigall, Agudeza y retórica en la poesía amorosa de cancionero, Santiago de Compostela, 1995, pp. 108 y 110-111. 
para encarnar los valores de la juventud y la esperanza ${ }^{189}$, como se observa en los colores heráldicos del duque de Saboya, Amadeo VI (1343-1383) -llamado "le Comte Vert"-, o la divisa dinástica creada en 1366 por su cuñado, nuestro conocido Louis II de Bourbon, en forma de cinturón verde con la palabra Esperance ${ }^{190}$. Este caso resulta especialmente significativo por los vínculos emblemático-caballerescos que había estrechado con Enrique II. Más arriba comentamos las bandas castellanas y probablemente cinturones franceses que ambos príncipes se intercambiaron en 1375-1376. Durante su estancia en Burgos, el duque pudo asistir a "las nupcias del infante de España, hijo del rey Enrique [Juan I de Trastámara], con la hija del rey de Aragón [Leonor de Aragón, hija de Pedro IV], celebrándose una gran fiesta según la costumbre" 191 . Se trataba de una significativa intervención de Louis de Bourbon en la vida del joven heredero, con quien tres años después, convertido ya en rey, negoció su regreso a Francia tras su segunda expedición a Castilla, escoltando a algunas damas de Catalina de Lancaster recién desposada con el primogénito de Juan I, el príncipe Enrique ${ }^{192}$. El duque debió renovar entonces su alianza con el monarca, pues en julio de 1387 acudió de nuevo con 2.000 lanzas para contener la última invasión angloportuguesa ${ }^{193}$.

Ante esta actividad caballeresca no parece aventurado suponer la difusión del verde emblemático francés en la corte castellana y su posible influencia en la opción cromática de Juan I que bien pudo asumir su semántica de la "esperanza" en relación con la empresa portuguesa, y asumir la simbólica cetrera que su contemporáneo Juan I de Aragón también había ensayado al adoptar el águila como signo de su aspiración al trono de Sicilia ${ }^{194}$. En el conflicto de legitimidades entre los Avis y los Trastámara, el halcón castellano de alas desplegadas y aceradas garras pudo expresar la reivindicación de un reino concebido como la justa presa de quien se aprestaba a reclamarlo con la fuerza de las armas. Sin embargo, el cazador resultó finalmente cazado, y el estandarte del halcón fue capturado durante la batalla, y enviado a Lisboa con los restantes despojos de la victoria. Por un procedimiento de apropiación simbólica, el halcón castellano acabó sobreviviendo en la heráldica municipal portuguesa, concretamente

${ }^{189}$ Michel Pastoureau, Le Vert. Une couleur en mutation à la fin du Moyen Age, en "Académie des inscriptions et belles-lettres. Comptes rendus des séances", 151-2 (2007), pp. 705-730; también en ID., Symboles du Moyen Age. Animaux, végétaux, couleurs, objets, París, 2012, pp. 304-305.

190 Se trataba de una divisa en forma de cinturón que se portaba alrededor del cuello, y el duque entregó a un número restrictivo de familiares, aliados y grandes señores extranjeros; cfr. Laurent HaвLOt, La ceinture Esperance et les devises des Bourbon, en Espérance. Le mécénat religieux des ducs de Bourbon à la fin du Moyen Age (F. Perrot, ed.), Souvigny, 2001, pp. 91-103.

${ }^{191}$ Oronville, Crónica del buen duque, ob. cit., cap. XXXVII, p. 80.

192 Ibidem, caps. LXIII-LXIV, pp. 114-116.

${ }^{193}$ Aunque las tropas francesas llegaron demasiado tarde, el rey "los recibió muy bien" y les pagó en Burgos las soldadas debidas; López de Ayala, Crónica de Juan I, ob. cit., año 1387, cap. IV y V, pp. 116-117; Froissart, Chroniques, ob. cit., vol. XII, pp. 128-131. Se considera que estas tropas sólo llegaron a Logroño en SuÁrez Fernández, Historia del reinado de Juan I, ob. cit., vol. I, pp. 268-269; Ignacio Iñarrea Las Heras, Los caminos de Santiago y los conflictos dinásticos castellanos en las "Chroniques" de Jean Froissart, "Thélème: Revista complutense de estudios franceses", 24 (2009), p. 115; LeGUAI, Le bourbonnais pendant la guerre de cent ans, ob. cit., p. 275.

${ }^{194}$ Así lo hizo desde que Federico de Sicilia falleciera sin herederos en 1377; RIERA I SANS, Els heralds i les divises del rei Martí, ob. cit., pp. 46-48. 


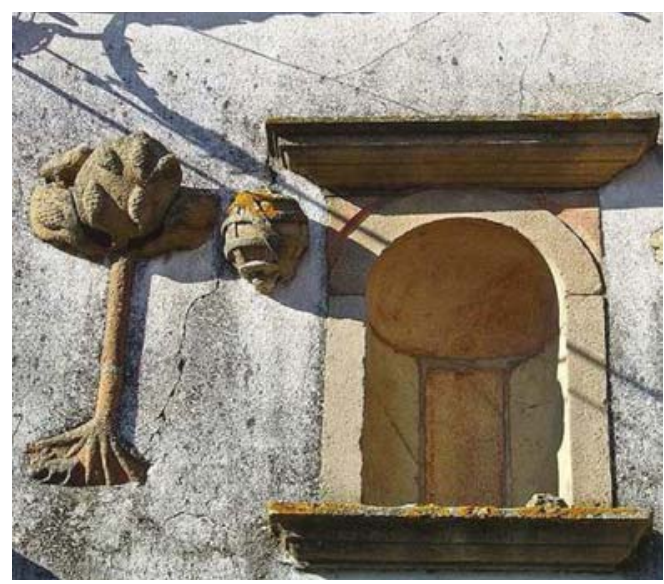

Fig. 20: Conjunto heráldico del antiguo hospital de la Misericordia. Pinhel (Portugal). El halcón incorporado al escudo de la ciudad se representa sobre el pino emblemático.

en las armas de la ciudad de Pinhel, cuyas tropas concejiles se hicieron con el estandarte de Juan I en Aljubarrota, y en memoria de este hecho incorporaron el halcón a las armas parlantes de su municipio (un pinheiro o pino), tomando también la designación de Pinhel-Falcão, Guarda-mor de Portugal (Fig. 20) ${ }^{195}$. Como señala Miguel Metelo de Seixas, João I debió conceder a la ciudad el uso de un halcón en sus armas en memoria de esta hazaña de acuerdo a un fenómeno de ennoblecimiento (acrescentamento honroso) que dejaba constancia de la fidelidad del municipio y su participación en el esfuerzo de la guerra.

El recuerdo de la divisa debió inspirar a Francisco Gómez de la Reguera cuando al atribuir a Juan I el azor en mano de cazador -"símbolo del ingenio y ardimiento"- con el mote maiora cedunt ("ceden los más grandes") (Fig. 21) ${ }^{196}$. El gentilhombre de la Cámara del Cardenal Infante explicaba la empresa por la tentación que tuvo el rey de "ceder el ánimo y valor a la necesidad [...] por algún accidente de la guerra o de la fortuna”, aludiendo quizá a su empeño por ocupar el trono portugués ${ }^{197}$. Se enfatizaba así el valor de la tenacidad ante las dificultades, que impresores y artistas del siglo XVI representaban mediante un halcón encapuchado con el lema post tenebras spero lucem ${ }^{198}$.

195 Debo esta preciosa referencia a Miguel Metelo de Seixas, que se apoya en una tradición fundada en fuentes variadas y retomada por el erudito seiscentista João Pinto Ribeiro, guarda mayor de Torre do Tombo; Miguel Metelo de SEIXAs, Heráldica, representação do poder e memória da nação, Lisboa, 2011, pp. 335-336; ID., As armas municipais de Pinhel, “Armas e Troféus", IX Série (2004), pp. 166167.

196 Sus Empresas de los reyes de Castilla fueron escritas en el primer cuarto del siglo XVII a instancias del Cardenal Infante Fernando de Austria, y sometida por tanto a las barrocas interpretaciones del momento. Sin embargo el autor tuvo acceso a bibliotecas y colecciones privilegiadas, como las que se albergaban en el Alcázar de Madrid; Francisco Gómez DE LA Reguera, Empresas de los reyes de Castilla y León, ed. César Hernández Alonso, Valladolid, 1990, pp. 109-113; semejante explicación se da en la obra de Jacobus Typotiu; cfr. José Julio GARcíA ArRAnZ, Symbola et emblemata avium: las aves en los libros de emblemas y empresas de los siglos XVI y XVII, La Coruña, 2010, pp. 498-499.

197 Estamos ante la imagen del rey cazador, dominador de la naturaleza, que con su inteligencia y sabiduría (ingenio) es capaz de gobernar sus reinos.

198 A fines de la Edad Media también aparece como representación del amor de Dios, como hace Piero I de Medici (1414-1469) al usar un halcón con un diamante entre sus garras con el lema semper, "queriendo significar - explica Giovio- que todas las cosas deben hacerse amando a Dios (Di amante)" y vencer así todas las conjuras que se abatieron sobre él; cfr. TERVARENT, Atributos y símbolos, ob. cit., pp. 284-286. 
No sabemos si Juan I volvió a exhibir la enseña perdida en Aljubarrota ${ }^{199}$. Su memoria parece perderse tras las brumas de la batalla, y su nombre ni siquiera figura entre las divisas reales mencionadas en la carta de $1410^{200}$. Sin embargo, el halcón Trastámara podría estar relacionado con la divisa que ostentaba Carlos Ramírez de Arellano, II señor de Cameros, como alférez mayor del pendón de la divisa del rey [Juan I], documentado en $1387^{201}$. El cargo se mantuvo en el reinado de Enrique III y la regencia de Fernando de Antequera hasta el fallecimiento de su titular en $1412^{202}$, coexistiendo con otros dos oficios: el alférez mayor del pendón de la Banda vinculado a los Ayala ${ }^{203}$, y el alférez mayor del pendón de la divisa del cordón de San Francisco que retenían los Osorio $^{204}$.

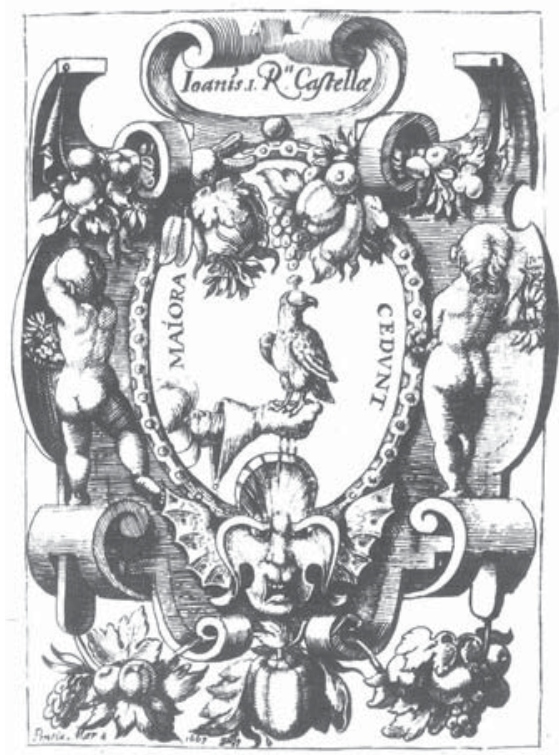

Fig. 21: Empresa de Juan I de Castilla reproducida por Francisco Gómez de la Reguera en sus Empresas de los reyes de Castilla (c. 1632).

${ }^{199}$ Cfr. Martins, A vida de Nun 'Alvares, ob. cit., pp. 282-283.

${ }^{200}$ Nos referimos a la carta real que prohibía el uso de las divisas reales sin la expresa autorización; en Juan Torres Fontes, Don Fernando de Antequera y la romántica caballeresca, "Miscelánea medieval murciana", 5 (1980), pp. 118-120.

${ }^{201}$ Ester González Crespo, Los Arellano y el señorio de los Cameros en la Baja Edad Media, "En la España Medieval", 2 (1982), pp. 406-407; en su testamento de 1385 Juan I nombró a Carlos Ramírez de Arellano alférez mayor del infante Fernando, pero no hallamos el título de alférez mayor del pendón de la divisa de Enrique III que le atribuye Ester González Crespo, pues este título se correspondía más bien con el de alférez mayor del pendón de la divisa del cordón de San Francisco vinculado a los Osorio y no podía existir en fecha tan temprana. Para complicar más las cosas, el privilegio rodado de 1387 que cita como confirmante a Carlos Ramírez de Arellano lo titula alférez mayor de la deuisa del pendón; Mercedes Borrero Fernández, Marcos Fernández y Pilar Ostos, Sevilla, ciudad de privilegios. Escritura y poder a través del privilegio rodado, Sevilla, 1995, p. 485.

${ }^{202}$ El oficio quedó vinculado a la familia, sucediendo en 1412 el primogénito Juan Ramírez de Arellano III que llegó a ser uno de los ricos hombres del tiempo de Juan II y Enrique IV; cfr. GonZÁLeZ Crespo, Los Arellano y el señorío de los Cameros, ob. cit., p. 407. Salazar y Acha considera que Juan Álvarez Osorio -señor de Villalobos y Castroverde y alférez de la extinguida orden del Espíritu Santosucedió en 1417 a Juan Ramírez de Arellano en el cargo de alférez mayor de la divisa del rey, cuando ya lo era del pendón de la divisa del cordón, dando a entender que ambas divisas eran la misma cuando no parece que así fuera; otra posibilidad es que la divisa de Juan I (el halcón o el Espíritu Santo) fuera subsumida por el alférez del pendón de la divisa del cordón de San Francisco; SAlAZAR y Acha, La Casa del Rey de Castilla y León, ob. cit., p. 447.

${ }^{203}$ El canciller Pedro López de Ayala (1332-1407) ostentaba este cargo en 1385, y en 1402 debió cederlo a su primogénito Fernán López de Ayala († 1436); cfr. SAlazAR y Acha, La Casa del Rey de Castilla y León, ob. cit., pp. 444-445; Garcia, Biografia de Don Pero López de Ayala, ob. cit., pp. 90-91.

${ }^{204}$ Cfr. Alfonso de CeBallos-Escalera y Gila, Un oficio bajomedieval desconocido: el alférez mayor del pendón de la divisa del cordón de San Francisco, "Banderas. Boletín de la Sociedad Española de Vexilología”, 69 (1998), pp. 6-9; y su versión revisada en Cuadernos de Ayala, 46 (2011), pp. 8-12. 
Más clara resulta su presencia en Alcón, rey de armas del rey de Castilla, que ingresó en la orden de la Vera Cruz fundada por el conde de Haro hacia $1455^{205}$. Su condición de rey de armas le sitúa en el nivel más alto de estos oficiales, algo inusual entre los titulares de las divisas que solían ser farautes o persevantes. Su antigüedad pudo facilitarle este honor en una corte como la de Juan II, donde la cetrería había recuperado el prestigio de tiempos de su abuelo, como prueba el ascenso del célebre cronista Pedro Carrillo de Huete (1380-1448), halconero mayor del rey ${ }^{206}$, y la reactivación de la literatura cinegética a cargo de Juan de Sahagún, cetrero del rey y autor del Libro de las aves que cazan, glosado después por Beltrán de la Cueva en sus Advertencias al libro de la cetrería de Juan de Sant Fagunt ${ }^{207}$.

\section{UNA CABALLERÍA REINVENTADA EN TIEMPO DE REFORMAS}

El fracaso militar de Aljubarrota supuso un tremendo revés a las espectativas político-dinásticas de Juan I. El monarca no se limitó a reconocer la derrota sino que interpretó los hechos como un castigo divino, merecido tanto por los pecados personales como los de sus súbditos ${ }^{208}$. Comenzó entonces un largo luto que duró

205 Antonio Paz y Melia, Biblioteca fundada por el conde de Haro en 1455, "Revista de Archivos Bibliotecas y Museos", 1 (1897), p. 458; sobre la orden de la Vera Cruz cfr. César Alonso DE PorREs Fernández, El Hospital de la Vera Cruz, en El Monasterio de Santa Clara de Medina de Pomar (N. López Martínez, y E. GonzÁlez TerÁn), Burgos, 2004, pp. 331-360; Miguel SÁnchez-Apellaniz DE Valderrama, Una orden de caballería desconocida: la divisa de la Vera Cruz fundada por el buen conde de Haro, "Cuadernos de Ayala", 22 (2005), pp. 9-14.

206 Cfr. Juan Torres Fontes, El Halconero y los halcones de Juan II de Castilla, "Murgetana", 15 (1961), pp. 9-20; ID., Pedro Calvillo, halconero mayor de Castilla, "Murgetana”, 18 (1962), pp. 7-8; Pedro Carrillo de Huete había heredado esta afición de su padre que había servido como montero mayor del infante Juan, el futuro Juan I; cfr. Óscar Perea Rodríguez, Carrillo de Huete, Pedro (1380-1448), en www.mcnbiografias.com; y las atinadas precisiones de $\mathrm{M}^{\mathrm{a}}$ Concepción QuintaniLla Raso, Consejeros encumbrados. El consejo real y la promoción de la nobleza castellana en el siglo XV', e-Spania [En línea], 12 | décembre 2011, Puesto en línea el 14 diciembre 2011, consultado el 30 julio 2012. URL: http://e-spania.revues.org/20680; DOI: 10.4000/e-spania.206; sobre las aficiones cinegéticas de Juan I cfr. Francisco de Paula CAÑAs GÁlvez, La cámara de Juan II: vida privada, ceremonia y lujo en la corte de Castilla a mediados del siglo XV, en Evolución y estructura de la Casa Real de Castilla (A. GAMBRA Gutiérrez, y F. LABrador Arroyo, coords.), vol. 1, Madrid, 2010, pp. 132-138.

207 Cfr. José Manuel Fradejas Rueda, Bibliotheca cinegetica hispanica: bibliografía critica de los libros de cetrería y montería hispano-portugueses anteriores a 1799, Londres, 1991, pp. 37-38; Ana María Rico Martín, “Libro de las aves que cazan” de Juan de Sahagún: edición crítica, Madrid, 1997; María del Pilar CARCELler CERVIÑo, La imagen nobiliaria en la tratadística caballeresca: Beltrán de la Cueva y Diego Enríquez del Castillo, "En la España medieval”, 24 (2001), pp. 271 y ss.

208 Cfr. César Olivera Serrano, La memoria de Aljubarrota en Castilla, en Actas das VI Jornadas Luso-Espanholas de Historia Medieval, vol. II, Universidade de Coimbra, 2009, pp. 277-294. Algunos ecos internacionales de la interpretación de Aljubarrota como castigo divino en Ignacio IÑARREA LAS Heras, Castilla y la Guerra de los Cien Años, entre 1337 y 1366, en la literatura francesa del siglo XIV, "Revista de literatura medieval", 24 (2012), pp. 137-138. Sobre la batalla añádase a la bibliografía citada Aljubarrota revisitada (J. G. MonteIro, coord.), Coimbra, 2001; João Gouveia MonteIRo, Aljubarrota, 1385. A Batalha Real, Lisboa, 2003. 
dos años hasta su clausura en las Cortes de Briviesca de $1387^{209}$. Cesar Olivera considera que este severo examen de conciencia motivó la revisión de la justicia y la reforma religiosa emprendida por el monarca para enmendar el yerro y recobrar el favor divino en un nuevo intento de recuperar la corona de Portugal ${ }^{210}$. A la irreductible conciencia de sus derechos sucesorios, Juan I añadía ahora un deseo de purificación de la memoria mancillada en Aljubarrota, que obedecía a una hipertrofia del sentido de la honra y una interpretación voluntarista de lo caballeresco ${ }^{211}$. Fernão Lopes lo expresa claramente al señalar que las reformas militares emprendidas en 1390 obedecían a "seu porfiado desejo de buscar todas as maneiras como da pasada deshonra podesse haver comprida vingança" ${ }^{212}$. El pecado y la incompetencia militar de aquella jornada aciaga debían ser expiados por una caballería reinventada donde la santidad y el coraje garantizaran el éxito de la nueva campaña, concebida como un acto de catarsis caballeresca y redención histórica.

La actitud del segundo Trastámara tuvo importantes consecuencias en la renovación emblemática incoada tras la derrota -con la difusión del Agnus Dei o Cordero pascual representado en las acuñaciones de 1386- y culminada en el marco de las Cortes de Guadalajara de 1390 con la creación de las divisas del Espíritu Santo y la Rosa. Se trató de una mutación simbólica que llevó al progresivo abandono de las criaturas exhibidas en la fracasada campaña por signos inequívocamente cristianos. Esta decisión no era completamente nueva. Respondía a la creciente sensibilidad del rey hacia este tipo de expresiones religiosas, como muestra la modificación de la era hispánica por la era cristiana en la Cortes de Segovia (1483) o la recuperación de las fórmulas medievales más solemnemente confesionales, con invocaciones verbales a la Virgen María o a la Santísima Trinidad especialmente desarrolladas ${ }^{213}$. Decisiones que no debían quedar en meras fórmulas cancillerescas en un monarca que clausuró la época de los bastardos reales y -a juicio de Villasandino- "por santo deviera ser canoniçado" 214 .

Los nuevos derroteros emblemáticos coincidían de hecho con una basculación religiosa de la caballería regia, que pasó del intento de crear una nueva orden militar de tintes cruzadistas, a fundar dos órdenes laicas de nuevo cuño vinculadas a las

${ }^{209}$ Las consecuencias en las costumbres lúdicas de la corte en Ramón MenÉndez PidAL, Poesía juglaresca y orígenes de la literaturas románicas, Madrid, 1957, p. 217.

${ }^{210}$ César Olivera Serrano, Devociones regias y proyectos políticos: los comienzos del monasterio de san Benito el Real de Valladolid (1390-1430), “Anuario de Estudios Medievales", 43-2 (2013), pp. 799-832.

${ }^{211}$ Cfr. Jorge Norberto Ferro, Ayala y la aventura portuguesa de Juan I, “Incipit”, 22 (2002), pp. 133-143.

${ }^{212}$ En otro lugar el cronista portugués insiste en la misma idea al afirmar que Juan I fundó las dos divisas para "cobrar Portugal e haver vingança da des'onra que na batalha [de Aljubarrota] decebera"; LoPes, Chronica de El-Rei D. João, ob. cit., vol. IV, cap. CXLIII, p. 67.

${ }^{213}$ María Luisa Pardo Rodríguez, Aportación al estudio de los documentos emitidos por la cancillería de Juan I de Castilla, "Historia. Instituciones. Documentos", 6 (1979), pp. 249-280; Elena E. Rodríguez DíAz, Un privilegio rodado extra-cancilleresco: La donación de la Casa de Noreña a la iglesia de Oviedo por Juan I de Castilla, "Asturiensia Medievalia", 6 (1991), pp. 234-235; Remedios Morán Martín, Eduardo Fuentes Ganzo, Ordenamiento, legitimación y potestad normativa: justicia y moneda, en Orígenes de la monarquía hispánica, ob. cit., p. 233.

${ }^{214}$ Cancionero de Juan Alfonso de Baena, ob. cit., p. 75. 


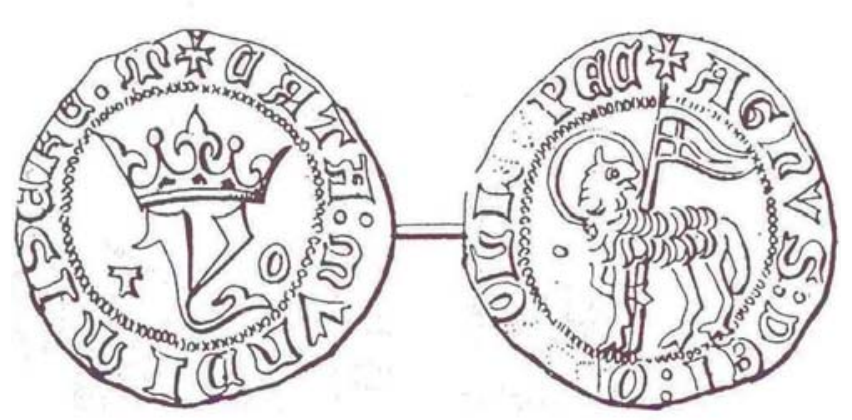

Fig. 22: "Y[oannes]" coronada (anverso), y Cordero pascual o Agnus Dei (reverso). Moneda Blanca del Agnus Dei acuñada por Juan I. Toledo.

divisas regias. Para Juan I, ya no serían grifos y dragones fabulosos, sino palomas pneumatológicas y corderos pascuales, los símbolos que guiarían a su nueva caballería refundada bajo el amparo de la Providencia. Con ello el rey mostraba una constante de su carácter: lo personal de la mayoría de sus decisiones y su disposición, por otra parte, a escuchar y a ser convencido ${ }^{215}$.

No es difícil advertir en la génesis de estos cambios, una frustración profética expresada por López de Ayala al aludir a los «libros de deuaneos, de mentiras prouadas» en su Rimado de Palacio ${ }^{216}$ y, años después, por Gutierre Díez de Gamés, al quejarse de la costumbre de aplicar profecías al nuevo rey, en vez de atenerse a la voluntad de $\operatorname{Dios}^{217}$. Si la derrota de Aljubarrota echaba un jarro de agua fría a los vaticinios de los Trastámara, la pérdida de sus enseñas dañaba el prestigio de unas divisas que debían renovarse para dotar al rey de un perfil más espiritual y, virtualmente, menos agresivo. Un cambio que puede estar relacionado con la emblemática defensiva y mariológica de su rival João de Avis, que usaba por divisa un matorral de espino con una rama florecida (pilriteiro) hacia 1385-1387218.

La primera de estas marcas fue el Agnus Dei o Cordero pascual importado de la iconografía francesa y grabado masivamente en las acuñaciones de 1386 para hacer frente a los gastos de la guerra contra portugueses e ingleses (Fig. 22) ${ }^{219}$. Al identificarse con la inicial del rey "Y[oannes]" coronada y grabada en su anverso,

${ }^{215}$ Gimeno Casalduero, La imagen del monarca en la Castilla del siglo XIV, ob. cit., p. 162.

${ }^{216}$ Pero López de Ayala, Rimado de Palacio, ed. de G. Orduna, Pisa, 1981, c. 163b.

217 "E si bien paras mientes, como viene rey nuevo, luego fazen Merlín nuevo. Dizen que aquel rey ha de pasar la mar e destruyr toda la morisma, e ganar la casa santa e á de ser emperador"; DíEZ DE GAMÉs, El victorial, ob. cit., cap. 19, p. 325.

${ }^{218}$ PaÇo D’Arcos, O pilriteiro, ob. cit., pp. 57-66; Laurent Hablot, “Aubépine (pilriteiro)”. Devise - CESCM - Maison de Portugal | Jean Ier de Portugal | Les familles. [En línea] Publicado en línea el 21 mayo 2013.URL : http://base-devise.edel.univ-poitiers.fr/index.php?id=235. Consultado el 15/01/2014.

219 Son las "blancas" del Agnus Dei con el Cordero pascual grabado en el anverso y la inicial del rey (la Y coronada) en el reverso; cfr. Felipe Mateu y Llopis, Acerca de la política monetaria de Juan I. La carta a la ciudad de Burgos sobre la baja de los blancos, 1388, "Boletín de la Comisión Provincial de Monumentos Artísticos e Históricos de Burgos y de la Institución Fernán González", 111 (1950-1951), pp. 483-489; Ricardo IzQuiERDo BENITO, La reforma monetaria de la segunda mitad del siglo XIV en Castilla y su reflejo en la documentación: los contratos de arrendamiento de la catedral de Toledo, en Actas del III Congreso Nacional de Numismática, Barcelona, 27 febrero - 1 marzo 1978, Madrid, 1979, pp. 491-497; José María de Francisco Olmos, La moneda en la Castilla bajomedieval. Medio de 
aquel Cordero pascual -símbolo de Cristo sacrificado en la cruz (Jn 1, 29-34) y de Cristo triunfante que recibe la adoración de las criaturas celestes (Ap. 5,8; 7, 10)ofrecía una imagen antitética a la del rey-halcón que en Aljubarrota se limitaba a usar su inicial sin corona ni referencias religiosas. Juan I deja de ser un conquistador para convertirse en víctima inocente -y al final victoriosa- de la reacción portuguesa y la campaña de Juan de Gante para ocupar el trono castellano ${ }^{220}$.

La letra Y o littera pythagorae asumía además una simbología cristológica al coronarse, representando la realeza de "Yesus" como señalan autores ibéricos del siglo XIV ${ }^{221}$. El segundo Trastámara apuntala así el sentido místico de su inicial, dotándola de una función emblemática sacra como referente de la majestad de Jesucristo. En el contexto de esta teología política, la corona proporciona una cierta legitimación, y la bifurcación o bivium representada en su angulosa grafía expresa la elección deliberada del monarca. No era un recurso novedoso. Pedro I ya había usado su inicial coronada en sus acuñaciones ${ }^{222}$, pero quizá sea ahora cuando esta representación adquiere una carga simbólica semejante a la empleada por su adversario portugués, João I, que usa la misma inicial a partir de 1415, en sus monedas de esta época o en la decoración arquitectónica de la iglesia de Santa Maria da Pena (Leiria) ${ }^{223}$. Este fenómeno supondría un nuevo caso de mimetismo emblemático entre dos monarcas rivales que acabaron usando los mismos signos en su discurso político.

El Cordero pascual no fue el único signo religioso que asumió el segundo Trastámara tras el varapalo militar. En los sellos de placa de 1387 y 1389 el rey hizo representar los dos escudos acolados de Castilla-León y Portugal, sostenidos por dos ángeles ${ }^{224} \mathrm{o}$ cuatro leones ${ }^{225}$, y timbrados con coronas de tres florones. Menéndez Pidal considera estos ejemplares como una de las primeras veces que se representan timbradas con corona las armas de Castilla ${ }^{226}$, aunque existe algún testimonio de tiempos de Enrique II en el palacio de Tordesillas y en la Capilla Real de Córdoba

propaganda e instrumento económico, en II Jornadas cientificas sobre Documentación de la Corona de Castilla (siglos XIII-XV) (J. C. Galende Díaz, coord.), Madrid, 2003, pp. 314-315.

${ }^{220}$ Sobre la simbología del cordero cfr. François Boespflug, Agneau, en Christianisme: dictionnaire des temps, des lieux et des figures (André Vauchez, dir.), París, 2010, pp. 17-19; Raquel Torres Jiménez, El cordero místico. Espiritualidad, iconografía y liturgia en la Edad Media, en Animales simbólicos en la historia, ob. cit., pp. 231-252.

${ }^{221}$ Agradezco a Laurent Hablot esta sugestiva referencia; cfr. Saul António Gomes, A Littera Pythagorae e a sua simbologia cristológica na Idade Média portuguesa, "Humanitas", 60 (2008), pp. 177-203.

${ }^{222}$ Elisa RuIz GARCíA, El poder de la escritura y la escritura del poder, en Orígenes de la monarquía hispánica, ob. cit., p. 308; González Díez, y MarTínez Llorente, El blasón heráldico, ob. cit., pp. 221-222.

${ }^{223}$ Gomes, A Littera Pythagorae, ob. cit., pp. 189-191; también Miguel Metelo de SeIXAs, Héraldique et inscriptions dans les monnaies portugaises de la dynastie d'Avis de Jean ler à Manuel $1^{\text {er }}$ (13831521), en Actes du colloque international Héraldique et numismatique III, Presses Universitaire du Havre, 2014 (en prensa). A quien agradezco la consulta de este trabajo antes de su publicación.

${ }^{224}$ Guglieri Navarro, Catálogo de sellos, ob. cit., vol. I, pp. 200-201 (n. 273).

${ }^{225}$ Filemón Arribas Arranz, Sellos de placa de las cancillerías regias castellanas, Valladolid, 1941, pp. 104-105 (n. 15-II). Una reproducción en AMADOR DE Los Ríos, José, Historia de la villa y corte de Madrid, vol. I, Madrid, 1860, p. 388.

${ }^{226}$ Menéndez Pidal, Heráldica de la casa real, ob. cit., pp. 285-286. 
$(1371)^{227}$. Al expresar el carácter institucional de la monarquía, la corona constituía el símbolo de una función, no de un hombre ni solamente de una dinastía ${ }^{228}$. Con ella se resaltaba la dignidad y el título del usufructuario de las armas, dialogando con los ángeles tenantes que sostienen las armas de Castilla y Portugal expresando el acto de dádiva divina que refuerza el carácter sagrado del pacto que une al rey y a Dios y resalta el apoyo de la Providencia a la unión de ambos reinos.

El propósito de enmienda de Juan I no sólo afectó a su emblemática. Su caballería, culpable de la derrota y dramáticamente golpeada por el brazo divino, también debió revisar sus presupuestos y acometer su propia conversión. Mientras se impulsaban las nuevas fundaciones monásticas, el rey quiso extender la reforma a sus tropas creando una nueva orden militar, imitando el ejemplo de Alfonso $\mathrm{X}$ al fundar la efímera Orden de Santa María de España (1272) ${ }^{229}$ o el de su abuelo Alfonso XI al intentar crear un ordo militiae que tampoco llegó a cuajar ${ }^{230}$. A diferencia de sus ancestros, Juan I tuvo éxito y, tras solicitar a la Santa Sede los permisos oportunos, erigió en Tarifa en 1388 -in opposito regni Benemarin- la nueva orden de San Bartolomé; advocación del monasterio jerónimo de Lupiana, muy vinculado al monarca ${ }^{231}$, y del colegio homónimo de la Universidad de Salamanca (1401) fundado por Diego de Anaya y Maldonado, asesor del monarca y posible impulsor de esta iniciativa caballeresca ${ }^{232}$.

La bula de Clemente VII señala como objetivo la defensa del reino y el pueblo cristiano contra las incursiones de los benimerines (ad defendendum regna tua et populum christianum ab incursibus infidelium), situando a la nueva orden en un horizonte más ideológico que funcional, pues no se registraron en aquellos años tensiones con los Meriníes o los Nazaríes ${ }^{233}$. La iniciativa también puede enmarcarse en el proceso de control monárquico sobre las órdenes militares que Juan I estaba promoviendo al obtener de la Curia aviñonense el derecho de proponer maestres

227 Pavón Maldonado, Nuevas aproximaciones, ob. cit., p. 175. En Aragón, Pedro IV usó un timbre de estas características en un contrasello de 1344, y en Portugal se documenta en tiempos de Fernando I (1367-1383); Mário Gomes Marques, Moedas de D. Fernando, Lisboa, 1978. En cuanto a los ángeles tenantes, la primera representación portuguesa se remonta al rey Dionís, en sus armas esculpidas del torreón del castillo de Estremoz, difundiéndose especialmente durante el reinado João I de Avis; João Paulo de Abreu e Lima, Armas de Portugal. Origem. Evolução. Significado, Lisboa, 1998, pp. 136 y ss.

${ }^{228}$ SeIXAs, El simbolismo del territorio, ob. cit., p. 298.

229 Eduardo Pardo de Guevara, La Orden de Santa María de España. Historia de una efimera fundación de Alfonso X, en Actas del Coloquio Internacional "Devoción Mariana y Sociedad Medieval", Ciudad Real, 1988, pp. 321-331; Miguel Ángel Rodríguez de la PeÑa, La Orden de Santa María de España y la Orden Teutónica: Apuntes en torno a un modelo de relación entre las Órdenes Militares y las monarquías europeas en el siglo XIII, "Mélanges de la Casa de Velázquez", 32-1 (1996), pp. 237-246; Juan Torres Fontes, Santa María de España, en Bériou, N., y Josserand, Ph. (dir.), Prier et combattre, ob. cit., pp. 845-846.

${ }^{230}$ Peter Linehan, Ideología y liturgia en el reinado de Alfonso XI de Castilla, en Génesis medieval del estado moderno: Castilla y Navarra (1250-1370) (A. RucQuoI, coord.), Valladolid, 1987, pp. 229-243.

${ }^{231}$ Bula de Clemente VII a Juan I, 28 enero 1388; en Luis SuÁrez Fernández, Castilla, el cisma y la crisis conciliar (1378-1440), Madrid, 1960, pp. 171-172.

${ }^{232}$ Sugestiva intuición que nos comunicó César Olivera Serrano. Una reciente aproximación al personaje en José María Monsalvo Antón, Diego de Anaya, fundador del Colegio de San Bartolomé y la política de su tiempo, en Miguel AnXo Pena (coord.), La Universidad pontificia de Salamanca en la Edad Media, Salamanca, 3-5 de diciembre 2013.

${ }^{233}$ Cfr. Ayala Martínez, San Bartolomé de Tarifa, ordre de, en Prier et combarte, ob. cit., p. 839. 
para las tres órdenes en $1384^{234}$. Como creador de la orden de San Bartolomé, el rey se erigía en caput militiae y restaurador de los antiguos ideales reconquistadores, aunque la falta de testimonios permite conjeturar el fracaso de aquel proyecto ante las nuevas formulaciones laicas que se estaban imponiendo en el mundo caballeresco.

Juan I optó por esta solución en 1390 creando dos nuevas divisas vinculadas a sus respectivas órdenes caballerescas, esta vez laicas y sometidas a la autoridad del rey. El segundo Trastámara imitaba de esta forma el ejemplo de Alfonso XI al crear la orden de la Banda sobre el proyecto enterrado de la frustrada ordo militiae. Sin embargo, la decisión regia se situaba en un marco más ambicioso de reforma general del reino, concretado en tres líneas de acción:

a) la reforma militar de la Cortes de Guadalajara, concluidas un mes antes de las fundaciones caballerescas, donde se pusieron las bases del nuevo ejército regio más reducido y ligado al rey (ordenamiento de lanzas) ${ }^{235}$;

b) la reforma nobiliaria tendente a desbancar a los antiguos parientes de Enrique II -los "epígonos" Trastámara- con una nueva "nobleza de servicio" más dócil a su idea de fortalecimiento monárquico ${ }^{236}$.

c) la reforma religiosa que, una vez asegurada en el sector monástico y el clero secular, debía alcanzar a los guerreros laicos poniéndolos bajo la tutela de las nuevas órdenes caballerescas ${ }^{237}$.

${ }^{234}$ SuÁrez Fernández, Historia del reinado de Juan I, ob. cit., vol. I, p. 355.

${ }^{235}$ Sobre las importantes Cortes de Guadalajara cfr. Cortes de los antiguos reinos, ob. cit., vol. II, pp. 460-464; Pedro López de Ayala, Crónica de Juan I, en Crónicas de los reyes de Castilla, ed. C. Rosell, Biblioteca de Autores Españoles, vol. 68, Madrid, 1953, pp. 132-133; y los análisis de Emilio Mitre Fernández, Las Cortes de Guadalajara de 1390 en el marco de la crisis política del siglo XIV, "Wad-al-Hayara: Revista de estudios de Guadalajara", 18 (1991), pp. 241-250; sobre la reforma militar Miguel Ángel LADERo QueSADA, La organización militar de la Corona de Castilla durante los siglos XIV y XV , en La incorporación de Granada a la Corona de Castilla (M. Á. LADERo QuesADA, ed.), Granada, 1993, pp. 195-227; ID., La organización militar de la Corona de Castilla en la Baja Edad Media, en Castillos Medievales del Reino de León, Madrid, 1989, pp. 11-34; Miguel Ángel de Benito Rodríguez, Estructura y organización del Ejército Trastámara. Aproximación a la Historia Militar castellana en la Baja Edad Media, "Revista de Historia Militar", 78 (1995); Fernando CAstillo CÁCEREs, La guerra y el ejército en los reinos cristianos peninsulares durante los siglos XIV y XV, en Aproximación a la historia militar de España, Madrid, 2006, pp. 143-166.

${ }^{236}$ Marie-Claude Gerbet, Las noblezas españolas en la Edad Media: siglos XI-XV, Madrid, 1997, pp. 179-182.

${ }^{237}$ Sobre el impulso dado a la reforma del clero secular y regular, y su apoyo a las nuevas fundaciones de cartujos y jerónimos cfr. Rafael SÁnchez SeSA, Don Pedro Tenorio y la reforma de las órdenes monásticas en el último tercio del siglo XIV: La vinculación del prelado a la espiritualidad jerónima, "En la España Medieval", 18 (1995), pp. 289-302; Santiago Cantera Montenegro, Los cartujos en la religiosidad y sociedad española, 1390-1563, vols. I-II, Salzburg, 2000; Vicente Ángel Álvarez Palenzuela, Historia de la Iglesia y religiosidad: nuevas perspectivas, en Medievalisme: noves perspectives (reunió científica: VII Curs d'Estiu Comtat d'Urgell, Balaguer, julio de 2002), Lérida, 2003, pp. 63-79; sobre el Ordenamiento de prelados aprobado el 27 de abril de 1390 para reformar las costumbres del clero (honestidad, guarda del celibato, salvaguarda de los bienes de la Iglesia, preocupación por la cultura del bajo clero, etc) cfr. SuÁrez Fernández, Historia del reinado de Juan I, ob. cit., vol. I, pp. 363 y ss. 
Los tres vectores apuntaban a una trasformación del gobierno, la Iglesia y el ejército ante la nueva campaña contra Portugal anunciada en las Cortes de Guadalajara de $1390^{238}$.

Restablecida la amistad con Inglaterra mediante el matrimonio de su primogénito con Catalina de Lancaster (1388), Juan I pudo retomar su proyecto militar bajo la nueva legitimación religiosa reflejada en sus divisas personales: la paloma del Espíritu Santo y la Rosa probablemente mariana; signos de inspiración cristiana que, en vez de anunciar profecías incumplidas, debían garantizar la protección divina y llevar a sus caballeros a la victoria. Estos signos daban forma a sus respectivas órdenes clientelares que proporcionaban cuadros organizativos sólidos a las tropas reales para "atender por força a os medos onde quer que lhe aviessen, ca não embargando o que lhe acontecera, ainda elle tinha outra vez vontade de vir contra o reino de Portugal" 239 .

Para llevar a cabo esta empresa cabía una nueva poética caballeresca que renovara el desprestigio de la Banda, despojada de su pendón y de su alférez, con nuevas devisas personales ${ }^{240}$. La "orden" generada por cada una creaba una caballería dentro de la caballería con un carácter restrictivo bajo el control del monarca ${ }^{241}$. Desde el punto de vista militar, la fórmula tenía sus ventajas. Juan I había tomado buena nota de los errores de Aljubarrota donde la vanguardia de sus tropas -"caballeros del Rey, que eran omes mancebos, e nunca se vieran en otra batalla"- arrastró al resto de las unidades a la trampa tendida por el Maestre de Avis ${ }^{242}$. Era preciso reforzar, por tanto, el control sobre aquella aristocracia indisciplinada que "con la voluntad que avian de pelear-escribía el rey a la ciudad de Murcia- fueronse sin nuestro acuerdo allá" ${ }^{243}$.

${ }^{238}$ Lopes, Chronica de El-Rei D. João, ob. cit., vol. IV, cap. CXLII, pp. 65-66.

${ }^{239}$ Ibidem, vol. IV, cap. CXLII, p. 67.

240 Sobre estas órdenes curiales surgidas del humus caballeresco tardomedieval véanse las interpretaciones - no siempre coincidentes- de Johan HuIzInGA, El otoño de la Edad Media. Estudios sobre la forma de vida y del espíritu durante los siglos XIV y XV en Francia y en los Países Bajos, Madrid, 1967, pp. 130-145; KeEN, La caballería, ob. cit., pp. 237-264; el pormenorizado análisis de Boulton, The knights of the crown, ob. cit.; y las síntesis recientes de Olivier MatTÉONI, Chevalerie (Ordres de), en Dictionnaire du Moyen Âge (C. Gauvard; A. DE Libera; M. ZInK, dirs.), París, 2004, pp. 282-284; D’Arcy Jonathan Dacre Boulton, Ordres laïques de chevalerie, en Prier et combattre, ob. cit., pp. 667-669; en ámbito castellano el tema ha sido tratado por MenÉndez PIDAL, Heráldica de la casa real de León y de Castilla, ob. cit., pp. 291-292; Torres FonTEs, Don Fernando de Antequera y la romántica caballeresca, ob. cit., pp. 83-120; y las obras citadas de Alfonso de Ceballos Escalera y Jesús Rodríguez Velasco.

${ }^{241}$ Rodríguez Velasco, El debate sobre la caballería, ob. cit., p. 122.

${ }^{242}$ En una de las notas a la Crónica se dice que Diego Gómez Manrique y Diego Gómez Sarmiento fueron los responsables del prematuro ataque que desencadenó la ofensiva de la vanguardia castellana; López de Ayala, Crónica de Juan I, ob. cit., cap. XIV, p. 103; circunstancia ponderada en MonTEIRO, Aljubarrota, ob cit., p. 104; Luis SuÁrez Fernández, Don Pedro López de Ayala. Un alavés clave de tres reinados, en Autour de Pedro López de Ayala (R. Amran, coord.), París, 2009, p. 78; en tiempos de los Reyes Católicos, Diego Rodríguez de Almela vuelve referirse al desorden de las tropas castellanas como causa determinante de las derrotas de Juan I ante los portugueses; Diego Rodríguez DE ALMELA, Copilación de las batallas campales, [Murcia, 1483], Cieza, 1963; cfr. Olivera Serrano, La memoria de Aljubarrota, ob. cit., p. 280.

${ }^{243}$ Carta de Juan I a la ciudad de Murcia, 26 agosto 1385; en López DE Ayala, Crónica de Juan I, ob. cit., cap. XIV, p. 152. 
Para solucionar estas carencias, el ordenamiento de lanzas de Guadalajara y las órdenes clientelares posteriores creaban una especie de ejército permanente usando los cuadros palatinos, robusteciendo los lazos entre el rey y sus guerreros en la línea ideológica del Bien Común impulsada para unir a los miembros de la sociedad política $^{244}$. Para sellar este acuerdo se establecía un nuevo juramento sagrado sellado con la entrega de un collar que funcionaba como emblema de alianza o vasallaje ${ }^{245}$. Las cláusulas de este pacto quedaron recogidas en el libro de ciertas condiciones que el rey mostró el día de la inauguración, comprometiéndose a completar con unas muy buenas ordenanzas pensadas, en el fondo, para paliar la mala ordenanza que provocó el descalabro de $1385^{246}$.

Junto a los objetivos militares, las nuevas órdenes tenían una función social: la renovación de las estructuras de la nobleza castellana, diezmada en Aljubarrota y en ambiguas relaciones con el rey. Los principales linajes que apoyaron a Enrique II en el conflicto sucesorio estaban desarbolados, y los parientes reales no dejaban de conspirar tratando de ejercer el poder de manera colegiada contra la autoridad real. Para neutralizar esta oposición, Juan I decidió en sus últimos años renovar el sector nobiliario con miembros de la segunda generación que le habían servido en sus empresas bélicas ${ }^{247}$. Se trataba de una "nobleza de servicio" reclutada de la aristocracia urbana y de la nobleza no titulada que triunfó en las Cortes de Guadalajara y debió promover las nuevas fundaciones como vías de promoción caballeresca. Al conceder estas marcas de distinción el rey reforzaba su autoridad como criador e fazedor de nobles $^{248}$, y al mismo tiempo dotaba a sus novi homines de una plataforma cortesana que oponer a los viejos cuadros de la Banda donde se parapetaban los parientes reales y los antiguos linajes petristas ${ }^{249}$. En el fondo, era la plasmación caballeresca de su idea de gobierno, consistente en fortalecer su autoridad y asegurar a su gobierno la participación funcional de un equipo de colaboradores ${ }^{250}$.

${ }^{244}$ Sobre el impulso de este principio jurídico-político durante el reinado de Juan I cfr. José Manuel Nieto Soria, Los fundamentos ideológicos, ob. cit., pp. 148-190.

${ }^{245}$ Keen, La caballería, ob. cit., p. 242.

${ }^{246}$ Así lo expresa Alfonso Álvarez de Villasandino en sus versos dedicados A la tumba del rey don Juan, recordando que en Aljubarrota "por mala ordenanza fue desbaratado"; en Cancionero de Juan Alfonso de Baena, ob. cit., p. 76.

${ }^{247}$ Los vientos de renovación soplaron en las Cortes de Guadalajara con el triunfo de la aristocracia urbana y la nobleza no titulada sobre los parientes reales de Enrique II; cfr. SuÁrez Fernández, Historia del reinado de Juan I, ob. cit., vol. I, pp. 380-381; GeRBEt, Las noblezas españolas, ob. cit., pp. 189-191.

${ }^{248}$ Sobre las consecuencias juridico-políticas de esta idea cfr. José Manuel NiETo Soria, La realeza caballeresca en la Castilla de mediados del siglo XV: representación literaria y formalización jurídicopolítica, en La chevalerie en Castille à la fin du Moyen Âge. Aspects sociaux, idéologiques et imaginaires (G. MARTin, dir.), París, 2001, pp. 61-80.

${ }^{249}$ Cfr. María Estela González de Fauve, Isabel J. Las Heras, y Patricia de Forteza, Simbología del poder en un linaje castellano: los descendientes de Pedro I excluidos de la línea sucesoria, "Cuadernos de Historia de España", 78 (2003-2004), pp. 47-66; ver también los linajes que incorporan la Banda y recoge Alonso de Torres en su Blasón y recogimiento de armas, finalizado en 1514-1515; Martín de RiQuer, Heráldica castellana en tiempos de los Reyes Católicos, Barcelona, 1986, pp. 108 y ss.

${ }^{250}$ Gimeno Casalduero, La imagen del monarca en la Castilla del siglo XIV, ob. cit., pp. 172-173. 


\subsection{LOS CABALLEROS DEL ESPÍRITU SANTO}

Los hechos han sido relatados por el canciller Ayala en un capítulo de su crónica titulado De las divisas que el rey don Juan fizo. Era el verano de 1390. El monarca pasaba los cinco primeros días de julio en el monasterio cisterciense de Sotos Albos en Collado Hermoso (Segovia) ${ }^{251}$. Allí mantuvo importantes conversaciones para la fundación de la cartuja de San María del Paular, que completaba la erección de Guadalupe efectuada el año pasado ${ }^{252}$. A la reforma de los religiosos siguió la de los caballeros, llevada a cabo en Segovia veinte días después de la entrada del monarca en la ciudad ${ }^{253}$. Durante este tiempo Juan I debió preparar las constituciones de las nuevas divisas y el acto de inauguración, celebrado en la catedral en una fecha cuidadosamente escogida: el 25 de julio, fiesta del apóstol Santiago patrono de la caballería.

"é el día de Santiago en la Iglesia mayor de la dicha ciudad dixo el Rey públicamente, que él avía ordenado de traer una devisa, la qual luego mostró allí, que era como un collar fecho como rayos de sol, e estaba en el dicho collar una paloma blanca, que era representación de la gracia del Espíritu Santo, e mostró un libro de ciertas condiciones que avía de aver el que aquel collar troxiese; e tomó el rey aquel collar de sobre el altar, e dióle a ciertos caballeros suyos. Otrosí fizo otra devisa que traían escuderos suyos, que decían la Rosa, é los que querían provar los cuerpos justando, o en otra manera, la traian. E por quanto á pocos días después desto finó el rey, non se troxieron más aquellas devisas, é non fablaron dello. Pero todo esto fizo con muy buen entención que, é si la voluntad de Dios fuera que él viviera, su voluntad era de facer muchas buenas ordenanzas ${ }^{\prime 254}$.

Se trata de un acto público de creación de dos devisas y sus correspondientes órdenes caballerescas. La doble fundación no suponía la extinción de la orden de la Banda -cuya insignia era complementaria con la nueva- pero ponía fin a su antiguo monopolio, estableciendo nuevas vías de promoción más especializadas y ligadas al rey. Tales órdenes mantenían la línea aperturista de la Banda -única orden monárquica que no requería para su ingreso la investidura caballeresca inusual a fines del siglo $\mathrm{XIV}^{255}$-, pero exigían a los candidatos su condición de vasallo, distinguiendo a los caballeros que habían recibido la investidura (orden del Espíritu Santo), de los escuderos que no la habían obtenido (orden de la Rosa). Esta distinción inexistente

${ }^{251}$ Se trataba de un inmenso cazadero de Alfonso XI; José Antonio VALVERDE, Anotaciones al Libro de la Montería del Rey Alfonso XI, Salamanca, 2009, pp. 724-725.

${ }^{252}$ Suárez Fernández, Historia del reinado de Juan I, ob. cit., vol. I, pp. 370, 389 y 414; ID., Juan I de Trastámara, ob. cit., p. 282.

${ }^{253}$ Luis Suárez documenta la estancia del rey en la ciudad el 5 de julio; BNE, Ms. 13.103, ff. 92rv; SuÁrez Fernández, Historia del reinado de Juan I, ob. cit., vol. I, p. 414.

${ }^{254}$ Ibidem, cap. XVIII de 1390; se reproduce la misma información en Lopes, Chronica de El-Rei D. João, ob. cit., vol. IV, cap. CXLII, p. 66.

${ }^{255}$ Boulton, The knights of the crown, ob. cit., pp. 46 y ss; Peter Linehan, Historia e historiadores, ob. cit., pp. 616 y ss. 
en la orden de la Banda introducía, por tanto, una nueva y elemental jerarquización en la caballería del rey ${ }^{256}$.

El ritual de inauguración sólo resulta comprensible a luz de los cambios operados en el pensamiento político a fines de su reinado. Como ha mostrado Gimeno Casalduero, la fundamentación enriqueña fue paulatinamente abandonada desde que João de Avis adoptara los mismos argumentos basados en la comunidad para defender su sucesión al trono portugués. Juan I reaccionó fundando sus derechos en la sangre a través de su matrimonio con Beatriz de Portugal (1483), o para defender su condición de rey de Castilla apelando a su entroncamiento con los Infantes de la Cerda, sucesores legítimos de Alfonso X, a través de su madre Juana Manuel, declarando ilegítimos a todos los descendientes de Sancho IV, segundogénito del rey sabio: no sólo Pedro I -con quien entroncaba el duque de Lancaster por su matrimonio con su hija Constanza-, sino su propio abuelo Alfonso XI y su padre Enrique II ${ }^{257}$.

Apoyándose en la concepción organicista, Juan I enfatizó su posición de cabeza del cuerpo del reino usando por primera vez clausulas identificadoras del poderío real absoluto ${ }^{258}$. Según la teoría de Walter Ullmann ${ }^{259}$, se estaría dando una paulatina basculación de la concepción "ascendente" del poder - prevalente en tiempos de Enrique II- a una concepción "descendente" que estrechaba los vínculos del rey con la divinidad sin cerrar a la comunidad el acceso al gobierno, como prueba la creación del Consejo Real a partir del pasaje mosaico de Ex. 18, 13-27260. Tomaba forma una peculiar teología política que en el plano eclesiológico llevará al abandono del conciliarismo por la defensa del papa de Aviñón, Clemente VII, a quien Juan I confió en 1385 la resolución del conflicto portugués ${ }^{261}$.

Desde el punto de vista ritual, el nuevo orden legitimador exigió la sustitución de las antiguas ceremonias de cooperación (juramentos e investiduras) por nuevos ritos con una mayor carga religiosa y una mayor dimensión dinástica que pivotaban sobre los

${ }^{256}$ En este sentido habría que corregir la afirmación de Rafael Ramírez de Arellano, que considera la presencia de la Banda entre los escuderos como un signo de devaluación de la orden en tiempos de Juan II; Ramírez de Arellano, La Banda Real de Castilla, ob. cit., p. 39.

${ }^{257}$ Sobre los testimonios que recogen este viraje legitimador cfr. Fernando GómEz Redondo, Don Juan Manuel, Trastámara, "Cahiers de Lingüistique et de civilisation hispaniques hispaniques médiévales", 25 (2002), pp. 163-181; Fernando Arias GuILLÉn, El linaje maldito de Alfonso X. Conflictos en torno a la legitimidad regia en Castilla (c. 1275-1390), "Vínculos de Historia", 1 (2012), pp. 147-163.

${ }^{258}$ Salustiano DE Dios, El ejercicio de la gracia regia en Castilla entre 1250 y 1530. Los inicios del Consejo de la Cámara, "Anuario de historia del derecho español”, 60 (1990), p. 332; José Manuel NIETO SORIA, La nobleza y el "poderío real absoluto" en la Castilla del siglo XV, "Cahiers de linguistique et de civilisation hispaniques médiévales”, 25 (2002), p. 240.

259 Walter Ullmann, Historia del pensamiento político en la Edad Media, Barcelona, 1983.

${ }^{260}$ No es extraño que el reinado de Juan I haya sido considerado el momento más intenso del proceso constitucional castellano, y al segundo Trastámara precursor del monarquismo constitucionalista; Modesto Lafuente, Historia General de España, vol. V, Barcelona, 1888, p. 255; recientes reflexiones al respecto en François Foronda, El Consejo de Jetró a Moisés (Ex. 18, 13-27) o el relato fundacional de un gobierno compartido en la Castilla de Trastámara, en Modelos culturales y normas sociales al final de la Edad Media (P. Boucheron; F. Ruiz Gómez, coords.), Universidad de Castilla-La Mancha, 2009, pp. 75-112.

${ }^{261}$ La sombra de Pedro Tenorio se advierte tanto en el discurso al duque de Lancaster, como en el nuevo rumbo eclesiológico de la corte castellana; SÁnchez SESA, Santiago contra Sao Jorge, ob. cit., p. 463. 
miembros de la familia real. Bajo este prisma cabría interpretar la solemnidad de las bodas de Juan I con Beatriz (1383), el alzamiento de ambos esposos en Toledo como reyes de Portugal, el matrimonio del heredero Enrique con Catalina de Lancaster (1388), la entrega de las insignias al nuevo príncipe de Asturias o la ceremonia de creación de las nuevas divisas regias (1390). En la mayor parte de los casos llama la atención el protagonismo de las personas reales y la exhibición de sus símbolos de poder. En las bodas de Badajoz ${ }^{262}$, Juan y Beatriz compartieron "un rico estrado" y entraron en la ciudad bajo palio dorado, retomando la insignia documentada por primera vez en la entrada sevillana de Alfonso XI (1337) ${ }^{263}$. El rey compareció entonces "muj reallmente" portando una corona de oro adornada de perlas ${ }^{264}$, como correspondía a un soberano que justificaba el uso de las insignias reales con el refrán: "quien bien se anunçia, bien le viene" 265 . De ahí que solemnizara la investidura de nuevos cargos cortesanos (1382) con la entrega de objetos simbólicos ${ }^{266}$, destinara importantes cantidades de dinero a embellecer las vestiduras regias ${ }^{267}$, y ostentara el estoque real en la recepción de León V de Armenia (1383) pues "do traen el espada alzada, viene el Rey de Castilla"'268.

${ }^{262}$ Sobre las bodas de 1383 contamos con el trabajo sin aparato crítico de Esteban RodRíGUEZ AmaYA, Bodas de Juan I de Castilla y Beatriz de Portugal (1383), "Revista de Estudios Extremeños", 1-2 (1948), pp. 67-93.

${ }^{263}$ Esta referencia al palio cubre el vacío documental existente entre el reinado de Alfonso XI y las entradas reales de los últimos Trastámara. Juan I pudo recuperar esta insignia por su afición a los usos ceremoniales de su abuelo que se habrían difundido en las ciudades de frontera. Fernão Lopes anota que el rey se dirigió a la catedral bajo un "pano douro temdido em astas, que cobria elle [Juan I] e o caballo [...] e tragiam quatro homrrados senhores"; Fernao Lopes, Cónica do senhor rei dom Fernando, nono rei destes regnos, Oporto, 1966, p. 459. Su hijo Enrique III volvió a usar esta insignia en su primera entrada en Segovia en junio de 1392; Diego de Colmenares, Historia de la insigne ciudad de Segovia, Segovia, 1637, p. 308. Cabe recordar otras formas de tronos adoselados como el magnífico ejemplar dibujado en la Genealogía de los Reyes de Castilla de Alonso de Cartagena (c. 1463); Biblioteca del Palacio Real (Madrid), Ms. 2.L1.2 ó Ms. II-3.009; ChaO CASTRo, Imágenes de poder de los reyes Trastámara de Castilla, ob. cit., n. 24. Sobre el palio como insignia de la realeza cfr. Félix MArTínez, El Palio: consideraciones histórico-canónicas en torno a un emblema pontificio, "Anales Melitenses", I (2002-2003), pp. 379-446; Fernández de Córdova Miralles, Los símbolos del poder real, ob. cit., pp. 37-58; Ana Isabel CARRASCo MANCHADO, Símbolos y ritos: el conflicto como representación, en La monarquía como conflicto, ob. cit., pp. 544-545; Teófilo F. Ruz, The Symbolic Meaning of Sword and Palio in Late Medieval and Early Modern Ritual Entries: The Case of Seville, "Memoria y Civilización", 12 (2009), pp. 13-48.

${ }^{264}$ No es extraño que Juan I sea considerado el primer monarca que incorporó la corona como timbre de sus armas; MenÉndez Pidal, La Heráldica medieval española ob. cit., p. 177. Gastos de seda para el bordado de la corona instalada en el sombrero del rey, o para embellecer la corona de la reina, en Villalobos y Martínez-Pontrémuli, Las gestiones hacendisticas de Diego López de Estúñiga, ob. cit., pp. 194 y 202; Martínez Martínez, La imagen del rey a través de la indumentaria, ob. cit., p. 286. ${ }^{265}$ Dicho refrán fue pronunciado por Juan I en las Cortes de Briviesca (1387); Cortes de los antiguos reinos, ob. cit., vol. II, p. 398; recordado oportunamente por NiETo SoRIA, La Realeza, ob. cit., p. 215.

266 Véase nuestra nota anterior y la descripción de la ceremonia de investidura de condestable en Salazar de Mendoza, El origen de las dignidades seglares, ob. cit., pp. 319-320.

${ }^{267}$ Cabe citar, por ejemplo, los 4.000 maravedíes gastados en Burgos por "dos pieças de panno imperiales coloradas" (1380); Villalobos y Martínez-Pontrémuli, Las gestiones hacendísticas de Diego López de Estúñiga, ob. cit., p. 184; sobre la cámara de los paños en tiempos de Juan I cfr. CAÑAS GÁlvez, La cámara de Juan II, ob. cit., pp. 149-152.

268 Según López de Ayala, ante la pregunta del armeno por la identidad del rey, le respondieron: "En esta gente que agora viene delante vos, do traen el espada alzada, viene el Rey de Castilla"; LóPEz 
Juan I fue más allá de la sensibilidad de su progenitor, que falleció en la cama real con "una vestidura de oro, e un manto de oro cubierto enforrado en peñas veras" 269 , pues trató de extender ciertos privilegios simbólicos y ceremoniales a los miembros de la familia real, especialmente su esposa y el príncipe heredero. En el primer caso ordenó que las ciudades juraran a Beatriz en 1383 "según se acostunbró fazer a las otras reynas que fueron en Castiella"270; y aunque su proclamación como reyes de Portugal "non plogo a todos los del su consejo", quiso celebrarla en el espacio propio de las coronaciones: la catedral de Toledo. Allí se asistió a una verdadera trasmutación de las personas reales al sustituir los "pannos pretos" del duelo por paños de oro forrados de armiño, y proceder al nombramiento del nuevo alférez real y al alzamiento del pendón de la doble corona ${ }^{271}$.

En este esfuerzo de legitimación dinástica el heredero fue promocionado al principado de Asturias (1388) mediante la solemne entrega del manto, corona y cetro $^{272}$. Era la consecuencia de una evolución ideológica que dotaba a las insignias reales de un valor dinástico reconocido por Juan I al ordenar en su testamento que su sucesor heredara "las coronas e las espadas de virtud" 273 . Se comprende así el trauma que supuso la pérdida en Aljubarrota del pendón real, los vasos y ornamentos de la capilla real, y el cetro de cristal y plata dorada -con delicadas labores de buril- que acabó en el convento lisboeta del Carmen ${ }^{274}$. De aquel desastre se salvó el yelmo coronado del rey ("bacinet du roy à tout le chappel d'or et de pierres") valorado en 20.000 francos que el caballero Martin Harens devolvió al soberano tras la batalla ${ }^{275}$.

La ceremonia segoviana de 1390 se sitúa en esta decantación del pensamiento Trastámara hacia una concepción descendente del poder. Así lo refleja la dimensión religiosa de aquellos actos que guardan más semejanza con ritos inaugurales que

DE AyALA, Crónica de Juan I, ob. cit., año 1383, cap. II, p. 81; algunos gastos en los estoques reales se comentan en CAÑas Gálvez, La cámara de Juan II, ob. cit., p. 153. Sobre el uso de esta insignia cfr. Fernández de Córdova Miralles, Los símbolos del poder real, ob. cit., pp. 50-52.

${ }^{269}$ López de Ayala, Crónica de Enrique II, ob. cit, año 1379, cap. III, p. 55.

${ }^{270}$ Véase la carta del rey al concejo de Murcia, 1 junio 1383; en Documentos de Juan I (J. M. Díez Martínez, A. Bejarano Rubio, Á. L. Molina Molina, ed.), Murcia, 2001, p. 229. César Olivera considera que el rey hizo una interpretación un tanto sui generis del derecho castellano, pues no había tal costumbre de jurar a la reina consorte; Olivera Serrano Beatriz de Portugal, ob. cit., p. 90.

${ }^{271}$ La frase es de López de Ayala, Crónica de Juan I, ob. cit., año 1383, cap. II, p. 81; y la ceremonia se describe en Lopes, Chronica de El-Rei D. João, ob. cit., vol. I, pp. 158-161; sobre este acto y sus consecuencias heráldicas cfr. Fernández de Córdova Miralles, Los emblemas de la conquista, ob. cit., pp. 232-233.

${ }^{272}$ En la descripción de Salazar de Mendoza, se dice que el príncipe fue asentado en "trono real" y el rey "vistióle un manto, y púsole un Chapeo en la cabeza, y en la mano una vara de oro, y dióle paz en el rostro, llamándole Príncipe de Asturias"; cfr. Pedro Salazar de Mendoza, El origen de las dignidades seglares, ob. cit., pp. 334-335.

${ }^{273}$ Schramm añade que, entre las disposiciones de su testamento, Juan I hizo figurar la de que su sucesor debía heredar "las coronas e las espadas de virtud"; Schramm, Las insignias de la realeza, ob. cit., p. 68.

${ }^{274}$ Era uno de los despojos de la batalla tomados por el condestable de Portugal, Nuno Alvares Pereira, y cedidos después al monasterio donde se hizo enterrar; Joseph Pereira DE SANTA AnNA, Chronica dos carmelitas da antiga e regular observancia nestes Reynos de Portugal, Algarves, e seus Dominios, vol. I, Lisboa, 1745, pp. 479-480.

275 Véase el relato de Froissart, Chroniques, ob. cit., vol. XI, pp. 184-189. 
con las ceremonias de cooperación y promoción de inicios del reinado ${ }^{276}$. El diálogo entre rey y súbditos que estas ceremonias suelen materializar quedó eclipsado por el protagonismo del soberano que convirtió a sus caballeros en meros espectadores de un acto del que es el absoluto dueño. La razón es que no se trataba de una mera investidura, sino de la fundación de un orden caballeresco que debía reflejar la nueva ideología monárquica, como hiciera el rey de Sicilia, Luis de Tarento, hacia 13521354 cuando creó la orden de la compañía del Espíritu Santo (Noud o compagnie du Saint-Esprit) para apuntalar su autoridad en un momento particularmente delicado en la consolidación dinástica ${ }^{277}$. Como el soberano napolitano, Juan I también usó la advocación al Espíritu Santo y la simbólica cristiano-caballeresca para redefinir su poder, pero su ideal no apelaba a la quimérica recuperación de Jerusalén, sino a la conquista del trono portugués que acariciaba desde su matrimonio con Beatriz de Avis.

Por su carácter inaugural, la ceremonia segoviana parece recuperar ciertos elementos de la coronación burgalesa. Como en 1379, se escogió la festividad del apóstol Santiago y el espacio sagrado de una catedral. El relato de López de Ayala y Fernão Lopes describen dos partes diferenciadas: la fundación de las órdenes caballerescas, y la entrega de sus insignias. El polo simbólico de la primera fase se sitúa en el altar ${ }^{278}$. Como ara del sacrificio de Cristo, constituía el lugar más sagrado del templo, y como representación del corazón del cristiano (Guillermo Durando) un lugar idóneo para exhibir los nuevos collares que adornarían el pecho de los caballeros ${ }^{279}$. El monarca acapara entonces toda la atención litúrgica en un acto también político pues "dixo el Rey públicamente, que él avía ordenado de traer una devisa".

A la disposición regia siguió la exhibición de la insignia ("la qual luego mostró allí") y del libro de sus estatutos ("e mostró un libro de ciertas condiciones que avía de aver el que aquel collar troxiese") estableciendo una curiosa analogía con los objetos propios de la ostensión litúrgica (ostensio): el Evangelio y la Sagrada Forma. El alzamiento del collar con la paloma del Espíritu Santo rodeada de rayos de sol guardaría cierta semejanza con la elevación de la custodia empleada en las

${ }^{276}$ Sobre las ceremonias de otorgamiento de dignidades Fernández de Córdova Miralles, La corte de Isabel I, ob. cit., pp. 360-365; Alfonso de CeBallos-Escalera Gila, Norma y ceremonia de los Almirantes de Castilla, Madrid, 2007; María Concepción Quintanilla Raso, El engrandecimiento nobiliario en la Corona de Castilla. Las claves del proceso a finales de la Edad Media, en ID. (dir.), Títulos, Grandes, del Reino y Grandeza en la sociedad política. Fundamentos en la Castilla Medieval, Madrid, 2006, pp. 19-31; NiETo SoRIA, Ceremonia y pompa, ob. cit., p. 64.

277 Cfr. Nicolas Bock, L'Ordre du Saint-Esprit au Droit Désir: enluminure, cérémonial et idéologie monarchique au XIVe siècle, en Art, cérémonial et liturgie au Moyen Age (Nicolas Bock, Peter KuRmanN, dir.), Roma, 2002, pp. 415-460; Boulton, The knights of the crown, ob. cit., pp. 211-240. No hemos consultado Alessandra Perriccioli Saggese, Gli Statuti dell'Ordine dello Spirito Santo o del Nodo. Immagine e ideologia del potere regio a Napoli alla metà del Trecento, Arturo Carlo Quintavalle (dir), Medioevo: immagini e ideologie", Milán, 2005, pp. 519-524.

${ }^{278}$ La deposición super altare ya se hacía con objetos simbólicos análogos en otros tipos de investiduras; Jacques Le GoFf, El ritual simbólico del vasallaje, en ID., Tiempo, traba jo y cultura en el Occidente medieval, Madrid, 1983, p. 374.

279 Guillermo Duranti, Rationale divinorum officiorum: libri I et III, ed. Stefano Della Torre, Massimo Marinelli, Massimo Marinelli, Ciudad del Vaticano, 2001, pp. 30-40; Dominique Iogna-Prat, Autel, en Christianisme: dictionnaire des temps, des lieux et des figures (André Vauchez, dir.), París, 2010, p. 67. 
exposiciones solemnes, especialmente con motivo de la festividad del Corpus Christi ${ }^{280}$. Las características de la custodia con un aro central (viril) -donde se coloca la Sagrada Forma- a modo de sol rodeado de rayos dorados recuerda el aspecto del collar Trastámara ${ }^{281}$. La ostensión de las constituciones también podría relacionarse con el alzamiento del Evangelio tras la lectura del Antiguo Testamento como anuncio de su proclamación, teniendo en cuenta el valor de este gesto en la proclamación del soberano en Castilla, simbolizada con el alzamiento del pendón regio ${ }^{282}$. A la luz de estas consideraciones, no es difícil advertir el trasfondo litúrgico de la ceremonia segoviana, donde los nuevos collares reciben una suerte de "consagración" sobre el modelo eucarístico para sellar el vínculo entre el monarca y sus hombres ${ }^{283}$.

López de Ayala describe la insignia del Espíritu Santo como "un collar fecho como rayos de sol, e estaua en el dicho collar una paloma blanca que era representación de la gracia del Spiritu Sancto" (Fig. 23a y 24a). No se trata de una vaga referencia a la tercera persona de la Santísima Trinidad, sino al descenso del Paráclito en Pentecostés: una representación impulsada al compás del desarrollo de la iconografía trinitaria ${ }^{284}$ y de la literatura catequética del siglo XIV ${ }^{285}$. Pentecostés constituía la festividad predilecta de la caballería para impartir la investidura, profesar los votos o convocar a sus miembros según el modelo literario del rey Arturo ${ }^{286}$, que siguen los estatutos de la Banda al reunir a sus caballeros en esta festividad, como más tarde

${ }^{280}$ Es en la primera mitad del siglo XIV cuando se va introduciendo la costumbre de exponer a vista de los fieles la Sagrada Hostia consagrada que dará pie al ceremonial del Santísimo Sacramento y el uso de custodias procesionales; cfr. Enrico Cattaneo, Il culto cristiano in Occidente. Note storiche, Roma, 1978, pp. 394 y ss; Cándido Pozo, Notas sobre la historia de la piedad eucarística, en ID., Estudios sobre Historia de la Teología: volumen en homenaje en su 80 aniversario, Toledo, 2006, pp. 275-277; Fermín Labarga García, Algunas notas sobre la fiesta del Corpus Christi, en Antonio Linage Conde (dir.), Minerva. Liturgia, fiesta y fraternidad en el barroco españo. Actas del I Congreso Nacional de Historia de las Cofradias Sacramentales, Segovia, 2008, pp. 75-89.

${ }^{281}$ Mario RighetTi, Historia de la Liturgia, vol. I, Madrid, 1954, pp. 520-540; Aimé Georges MARTIMORT, La Iglesia en oración, Barcelona, 1967, pp. 501 ss. y 510-519; sobre la evolución de la custodia en la península Ibérica véanse los trabajos generales de Manuel Trens, Las custodias españolas, Barcelona, 1952; Maria Victoria Herráez Ortega, Orfebrería y liturgia en la Baja Edad Media. El programa iconográfico de la custodia procesional de Córdoba, "Anales de la Historia del Arte", 4 (1993), pp. 783-791.

282 Armando Represa Rodríguez, El Pendón Real de Castilla y otras consideraciones sobre el reino, Valladolid, 1983, pp. 11-12 y 21-36.

${ }^{283}$ Aunque es difícil sostener un origen genético del ritual eucarístico, la ceremonia segoviana muestra signos evidentes de su inspiración.

${ }^{284}$ Sobre la iconografía del Espíritu Santo cfr. Stephan Seeliger, Die Ikonographie des Pfingstwunders, Munich, 1956; François Boespflug, Figurer l'Esprit Saint, "Les dossiers de la Bible", 39 (1991), pp. 14-18; José Antonio ÍÑguez, La iconografía del Espíritu Santo en la Iglesia latina, "Scripta Theologica", 30/2 (1998), pp. 559-586; Rosanna Ferrari, Pentecoste, en Iconografia e arte cristiana (L. CAstelfranchi; M. A. CripPa, dirs.), vol. II, Milán, 2004, pp. 1052-1053; Michel Gitton, Esprit Saint, en Christianisme: dictionnaire des temps, des lieux et des figures (André Vauchez, dir.), París, 2010, pp. 206-210.

${ }^{285}$ Véase, por ejemplo, la miscelánea catequética conservada en el Ms. 77 de la Biblioteca Menéndez Pelayo, de la primera mitad del XIV, donde se explora la simbología de los bestiarios con referencia a la Paloma y sus siete virtudes (f. 384); cfr. Fernando Gómez Redondo, Historia de la prosa medieval castellana, ob. cit., vol. II, pp. 1861-1871.

${ }^{286}$ Porro GIRARDi, La investidura de armas en Castilla, ob. cit., p. 329. 


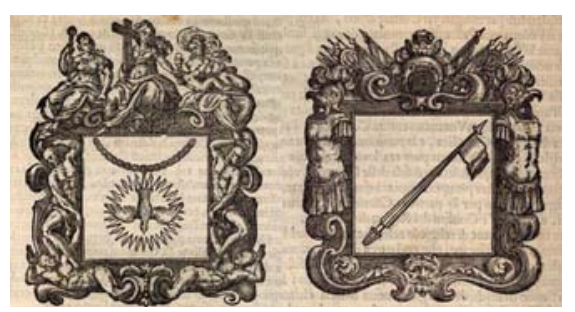

Fig. 23: a) y b) Insignias de la orden de la Paloma y de la Razón, reproducidas por Bernardo Giustiniani en sus Historie cronologiche dell'origine degl'ordini militari (1672).
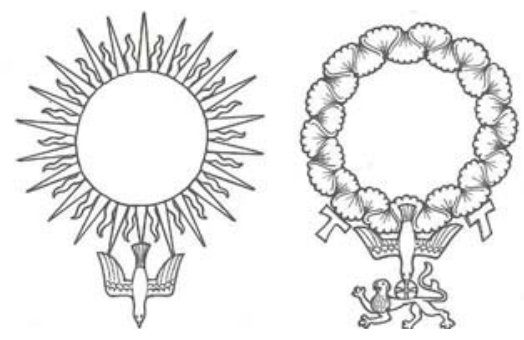

Fig. 24: a) y b) Collar del Espíritu Santo de Juan I de Castilla (1390) en la versión hipotética de Boulton (izquierda), y representación que figura en la lápida de Nicolas von Diesbach (derecha), probablemente el collar de San Antonio de Cleves. Dibujos: D'Arcy Jonathan Dacre Boulton.

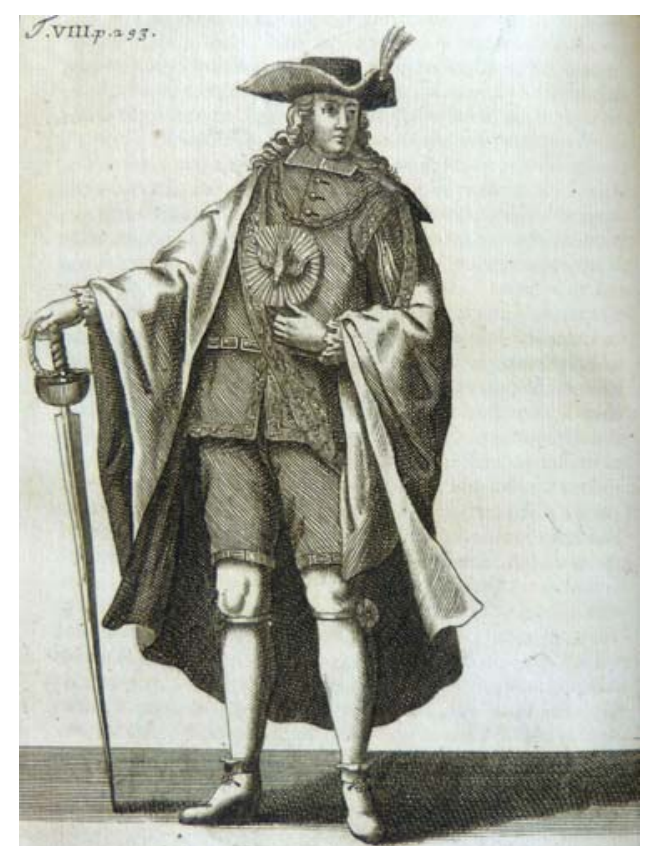

Fig. 25: Miembro de la orden del Espíritu Santo (Chevalier de la Colombe). Grabado reproducido en Pierre Hélyot, Histoire des ordres monastiques, religieux et militaires, et des congregations seculieres, vol. VIII, París, 1719, cap. 42, p. 293 (ilustración n. 51).

hará la fraternidad de la Tabla Redonda creada por Eduardo II de Inglaterra ${ }^{287}$. La entrada en la nueva corporación se equipara ahora a la efusión pneumatológica del amor divino que desciende en forma de llamas de fuego sobre el colegio apostólico ${ }^{288}$. Estos "rayos de sol" despliegan su potencia lumínica en el grabado del diccionario de Pierre Hélyot, editado a principios del siglo XVIII (Fig. 25) ${ }^{289}$, pero desaparecen en el retrato de Juan I de Castilla (1848) realizado Vicente Arbiol y Rodríguez (Fig. 26), que se limitó a representar la paloma como pinjante del collar ${ }^{290}$.

287 Véanse las constituciones analizadas por RodríguEz Velasco, Ciudadanía, soberanía monárquica, ob. cit., pp. 200 y 213. La posible inspiración castellana de la orden inglesa se fundamenta en las relaciones de Castilla e Inglaterra que llevaron a los earls de Derby y Salisbury a participar en el sitio de Algeciras en el otoño de 1343; Boulton, The knights of the crown, ob. cit., pp. 109-110; Hugh E. L. Collins, The Order of the Garter, 1348-1461: chivalry and politics in late medieval England, Oxford, 2000, p. 8.

${ }^{288}$ La caridad se interpreta en la versión carismática de San Pablo, como un don gratuito otorgado para la construcción del cuerpo de Cristo (1 Co 12,4).

289 Pierre HéLYot, Histoire des ordres monastiques, religieux et militaires, et des congregations seculieres, vol. VIII, París, 1719, cap. 42, p. 293 (ilustración n. 51).

${ }^{290}$ Se trata del lienzo que forma parte de la "Serie cronológica de los reyes de España" encargada por José de Madrazo a diversos pintores en 1847. Tras exponerse durante un tiempo en el museo del Alcázar 
Desde el punto de vista caballeresco, la paloma pneumatológica podía simbolizar la fidelidad y fraternidad entre los miembros. Bajo la sombra protectora del Paráclito, el perfil del nuevo caballero se recorta sobre la silueta de los discípulos de Cristo mientras la corte del rey se convierte en reflejo de la Iglesia naciente ${ }^{291}$. Una imagen cada vez más familiar a una sociedad curial que había incorporado el misterio trinitario a los debates cortesanos ${ }^{292}$. La nueva fundación expresaba una clara teología política inspirada en el modelo eclesiológico descrito. La trasposición de elementos es elocuente: la unidad de la Iglesia/reino se fortalece con los dones del Espíritu Santo/ rey que se derraman sobre los nuevos apóstoles/caballeros renovados en el crisol de Pentecostés. El monarca se presenta como mandatario del Paráclito mostrando en una misma ceremonia su condición de caput militiae ("cabeza de la caballería") y hunctus rex ("rey ungido"); dos facetas -la caballeresca y la política- que venían aproximándose desde los inicios del reinado. La conexión entre una y otra venía dada por la tercera persona de la Santísima Trinidad, objeto de particular devoción de la realeza castellana y que Enrique II promovió como fundador de un grupo de clérigos "que llaman de Santi Espiritus" para rogar a Dios por el alma de su padre Alfonso XI y la suya $(1371)^{293}$. Con Juan I esta pietas dinástica no sólo se desarrolló con sofisticadas invocaciones a la Trinidad en sus privilegios reales, sino que adquiere una nueva dimensión ceremonial en la figura del "rey ungido" antes de que esta expresión se consolide en tiempos de Juan II y Enrique IV ${ }^{294}$.

Desde la perspectiva emblemática, la nueva orden asumió unos signos que no eran especialmente novedosos. Como hemos comentado, Luis de Tarento había usado la paloma con un haz de rayos como motivo de la orden del Nudo a mediados del

de Segovia, fue devuelto al Museo del Prado en 2004 (número de catálogo P06904), y depositado en el Congreso de los Diputados (Madrid); Alfonso Emilio Pérez Sánchez, La serie iconográfica de los Reyes de España en relación con el Alcázar de Segovia, Segovia, 1989; Cien años de pintura en España y Portugal (1830-1930), vol. II, Madrid, 1991, p. 200; ver también la ficha del museo en la dirección electrónica: www.museodelprado.es/coleccion/galeria-on-line/galeria-on-line/obra/juan-i-decastilla/?no_cache $=1$.

${ }^{291}$ Un topos recurrente que reaparece en las justas de Valladolid de 1428, cuando Juan II compareció disfrazado de Dios Padre rodeado por sus nobles, identificados con los doce apóstoles con su rótulo respectivo y la señal del martirio; Lope DE BARRIentos, Refundición de la crónica del Halconero, ed. J. de M. Carriazo, Madrid, 1956, p. 63; Pedro Carrillo de Huete, Crónica del Halconero, ed. J. de M. Carriazo, Madrid, 1946, p. 25; el análisis tan discutible como sofisticado de Teófilo F. RuIz, Fiestas, torneos y símbolos de realeza en la Castilla del siglo XV. Las fiestas de Valladolid de 1428, en Realidad e imágenes del poder, ob. cit., pp. 258-260; estas nuevas formas de expresión política tenían sin embargo raíces profundas, como puso de manifiesto Manuel GarCíA-Pelayo, El Reino de Dios, arquetipo político: (estudio sobre las formas políticas de la Alta Edad Media), Madrid, 1959.

${ }^{292}$ Cfr. José L. Labrador Herráez, Las preocupaciones doctrinales de los poetas del Cancionero de Baena, "Boletín de la Institución Fernán González", 181 (1973), pp. 882- 915.

${ }^{293}$ Según Ambrosio de Morales estos clérigos celebraban "el primero dia de cada mes una Misa cantada en el altar mayor con gran solemnidad, es del Espiritu Santo y por el ensalzamiento de los Reyes de Castilla, y por su vida y salud"; Ambrosio de Morales, Relación del Viage que Ambrosio de Morales, cronista de S.M., hizo por su mandado el año de 1570 en Galicia y Asturias, en Las antigüedades de las Ciudades de España que van nombradas en la Corónica con las averiguaciones de sus sitios y nombres antiguos, Madrid, 1792, p. 164; citado por David Nogales Rincón, La representación religiosa de la Monarquía castellano-leonesa: la Capilla Real (1252-1504), Madrid, 2009, pp. 112-113.

${ }^{294}$ Nieto Soria, Los fundamentos ideológicos, ob. cit., pp. 60-65. Sobre las invocaciones verbales cfr. Rodríguez Díaz, Un privilegio rodado extra-cancilleresco, ob. cit., p. 234. 
siglo XIV, y en 1370 los Visconti la emplearon con un sentido legitimista ${ }^{295}$. Eran manifestaciones de la devoción trinitaria que estaba permeando la emblemática europea, incluida la península Ibérica donde el rey de Navarra, Carlos II de Évreux (1349-1387) eligió como divisa el trifolio o triple lazo - un cifrado de las tres Personas divinas- tal vez por imitación de su madre Juana de Francia ${ }^{296}$. En el caso castellano, es posible que la orden de San Francisco -tradicional difusora de la devoción pneumatológica ${ }^{297}$ - influyera en la opción emblemática de Juan I, poco antes de que su primogénito Enrique adoptara el cordón franciscano como divisa personal ${ }^{298}$.

En la literatura castellana, la paloma era considerada un animal "limpio et mesurado" que -como el Cordero pascual-expresaba los valores de inocencia, pureza y paz ${ }^{299}$. Su representación adornó el cetro de Alfonso X en su efigie de la capilla de la catedral de Sevilla, representando el gobierno pacífico inspirado y presidido por el Espíritu Santo que, en el rito de la unción, desciende sobre el soberano al recibir el santo óleo ${ }^{300}$. Signo de comunicación entre cielo y tierra, la paloma expresaba la concepción del poder que emerge en la última etapa del reinado de Juan I, con un rey que pretende resurgir de las cenizas de empresas fracasadas. Una visión redentora que está presente en relatos vinculados a la paloma como representación de la gracia que retorna al pecador arrepentido ${ }^{301}$, o que podía representar al propio rey ${ }^{302}$, por considerarse la más hermosa de las animalías ${ }^{303}$.

Desde la perspectiva caballeresca era un ave apta para recibir los votos o promesas por su parentesco con el pavo, a quien los caballeros apelaban en los famosos "votos

${ }^{295}$ Esta orientación se advierte en el lema A Bon Droit que los Visconti empleaban con la paloma, al menos desde tiempos de Valentina, casada en 1389 con Luis de Valois, hermano de Carlos VI y futuro duque de Orleans; Навцот, La devise, mise en signe du prince, ob. cit., p. 266.

${ }^{296}$ Cfr. Narbona Cárceles, Le roi de la Bonne Foy, ob. cit., p. 496.

${ }^{297}$ Cfr. François Vandenbroucke, Devotion a l'Esprit Saint, en Dictionnaire de spiritualité, ob. cit., vol. IV-2, col. 1316.

${ }^{298}$ Cfr. Fernández de CóRdova, El cordón y la piña, ob. cit.

${ }^{299}$ Nos referimos a los versos del arcipreste de Hita en su Libro del buen Amor (c. 1330-1343): "Sé como la paloma, limpio e mesurado / Sé como el pavón, loçano, sosegado"; María Rosa LiDA DE Malkiel, Juan Ruiz: selección del Libro de Buen Amor y estudios críticos, Buenos Aires, 1973, p. 63. Sobre la glorificación de la paloma como animal espiritual y puro en la tradición cristiana cfr. VOISENET, Bêtes et Hommes, ob. cit., pp. 133-134; Salvador Novo, Las aves en la poesía castellana, México, 2005, pp. 25 y ss.

${ }^{300}$ Memoria de Hernán Pérez de Guzmán sobre los sepulcros de la Capilla Real de Sevilla (1345) en Ortiz de ZúNIIGA, Anales eclesiásticos y seculares, ob. cit., vol. I, p. 144; Manuel García Pelayo, Ideología e iconografia, "Anthropos", 59 (1986), p. 25; también NogALEs RincóN, La representación religiosa, ob. cit., pp. 1101-1102. Las referencias a la paloma como símbolo de paz tomado del relato de Noé, y de elección divina, reflejado en el pasaje del bautismo de Cristo en el Jordán, se exponen en las Partidas, I, ley XLVII, pp. 104-106.

${ }^{301}$ Véase el relato atribuido a Dionisio Areopagita que se recoge en el Libro de los exemplos por A.B.C (c. 1435), donde la relación de Dios con un sacerdote arrepentido se expresa mediante una paloma que entra y sale de su boca; Clemente Sánchez de Vercial, Libro de los exemplos por A.B.C, ed. Andrea Baldissera, Pisa, 2005, pp. 113-114 (n. 110).

${ }^{302}$ Como sucede en los versos dedicados a Enrique III en Cancionero de Juan Alfonso de Baena, ob. cit., p. 149; cfr. Montero Curiel, y Montero Curiel, El léxico animal, ob. cit., pp. 322-323

${ }^{303}$ Véase el Libro de los gatos compuesto en la segunda mitad del siglo XIV; Libro de los gatos, ed. de B. Darbord, París, 1988, pp. 62-63. 
del pavón" (Vøeux du Paon) que empezaban a difundirse en Castilla en el último cuarto del siglo XIV ${ }^{304}$. La referencia al "libro de ciertas condiciones que avía de aver el que aquel collar troxise" permite sospechar la existencia de algún tipo de juramento o voto caballeresco relacionado con la aventura portuguesa $a^{305}$. El cuerpo de caballeros se cerraría con el nombramiento de un alférez portador del pendón de la orden, que recayó en Juan Álvarez Osorio II conde de Villalobos ${ }^{306}$.

La segunda etapa de la ceremonia consistió en la entrega de los collares a los nuevos miembros. El rey los tomó del altar y probablemente los fue imponiendo a cada uno en un gesto que recuerda la investidura caballeresca o la entrega de objetos simbólicos (anillo, estoque, estandarte) en las ceremonias de promoción a determinadas dignidades. Desde el punto de vista religioso, la imposición del collar puede relacionarse con la investidura del hábito (cordón, cinturón o escapulario) siguiendo la modalidad difundida por las órdenes mendicantes para el ingreso en la orden tercera o en cofradías afiliadas ${ }^{307}$. El collar caballeresco sería por tanto una estilización del hábito-escapulario cuya imposición simbolizaría el ingresoagregación del candidato ${ }^{308}$. Éste debía asumir los compromisos recogidos en el "libro de las condiciones" que garantizaban una mínima organización a esta "orden monárquica o curial", según la taxonomía de Boulton ${ }^{309}$. El texto presentado en Segovia se trataba, sin embargo, de un boceto que el monarca pensaba completar con unas "buenas ordenanzas", otorgándoles carácter legal como había hecho con el Segundo Ordenamiento de la Banda.

Junto a los aspectos institucionales, es preciso considerar los factores espirituales que explican el nacimiento de estas órdenes entre el proyecto enterrado de una orden militar y la envejecida orden de la Banda. Con fina intuición César Olivera ha detectado en las nuevas fundaciones la creación de "un tipo de caballero cristiano no vinculado al régimen de vida de las órdenes militares aunque sí especialmente unido a la corona, con una exaltación de virtudes castrenses y espirituales que no podemos precisar" ${ }^{\prime 10}$. El caballero del Espíritu Santo ya no era un simple torneador dispuesto a

${ }^{304}$ La ceremonia se documenta por primera vez en la fiesta de coronación de la última esposa de Pedro IV de Aragón, Sibilia de Fortià, en 1381; y después en Castilla, a tenor de la impronta que dejó en la Crónica carolingia escrita entre 1388 y 1390; cfr. BAUTISTA, Francisco, El motivo de los Nueve de la Fama en El Victorial y el poema de Los Votos del Pavón, "Atalaya", 11, Hétérogénéité et transferts, avril 2009 [en línea], puesto en línea el 20 abril 2009. Consultado el 04 marzo 2010.

305 Jesús Demetrio Rodríguez Velasco, Le sens du vœu dans les ordres chevaleresques européens du Moyen Age, "Cahiers du Centre de recherches historiques", 16 (1996), pp. 65-73.

306 Salazar de Mendoza, El origen de las dignidades seglares, ob. cit., pp. 354-355.

${ }^{307}$ El interés de Juan I por las asociaciones impulsadas por las órdenes mendicantes en Cortes de los antiguos reinos, ob. cit., vol. II, p. 303.

${ }^{308}$ Henri LeclercQ, Scapulaire, en Dictionnaire d'Archeologie chretien et liturgie, vol. XV, París, 1953, p. 986; A. Michel, Scapulaire, en Dictionnaire de Théologie, vol. XIV-1, París, 1939, cols. 12541259; especialmente García M. Colombás, y Ludovico SAGgi, Abito religioso, en Dizionario degli istituti di perfezione, vol. I, Roma, 1974, cols. 50-62; Ludovico SAGGI, Scapulaire, en Dictionnaire de spiritualité. Ascétique et mystique. Doctrine et histoire, vol. XIV, París, 1990, cols. 390-396.

${ }^{309}$ Según esta clasificación, la fundación de Juan I se distinguiría de los otros tres tipos de agrupaciones caballerescas (confraternales, fraternas y votivas); cfr. Boulton, The knights of the crown, ob. cit., pp. 326 y ss; aunque a veces se la considere una pseudo orden clientelar (cliental pseudo-order).

310 Olivera Serrano, Devociones regias, ob. cit., pp. 808-809. 
servir al rey -como los miembros de la Banda-, sino un caballero-apóstol, purificado por el fuego del Espíritu y revestido con el blanco emblemático de la paloma, símbolo de pureza, castidad e inocencia ${ }^{311}$.

Según Andrés Mendo, sus estatutos ofrecían un código ético basado en las virtudes de la castidad y la fortaleza para defender la fe frente a los musulmanes ${ }^{312}$, lo que supone un deslizamiento del antiguo ideal de la Banda-centrado en la lealtad al reyhacia una espiritualidad más interiorizada. Bernardo Giustiniani profundiza en esta idea al referirse al "religioso genio" de Juan I, "essemplare perfetto di Santità", que añadió a su orden unos compromisos morales y espirituales concretados en comulgar todos los jueves - día conmemorativo de la Última Cena- y guardar la castidad conyugal imitando la pureza de la paloma ${ }^{313}$; se reforzaba así el dispositivo ético de la caballería en búsqueda de una perfección laical dentro del status conyugal y el oficio de las armas. Aludiendo a una supuesta crónica atribuida a José de Sigüenza, también se recuerdan sus objetivos de "defensa de la fe católica y de los reinos de Castilla [y] el amparo de las doncellas, viudas y pupilos, estendiéndose a otros empleos piadosos respecto al estado eclesiástico, con la pension de rezar cada dia por el aumento de su órden y rogar por las almas de sus difuntos caballeros"314. Un programa de vida que retomaría Fernando de Antequera en 1403 al convertir la devoción mariana y la castidad personal en los puntales éticos de su orden de la Jarra y el Grifo.

El deseo de perfección laical no era nuevo. Don Juan Manuel ya había apelado a la santidad en el mundo como alternativa a la santidad religiosa ${ }^{315}$, estableciendo un paradigma reformulado por la novelística caballeresca desde Amadís de Gaula -que abandona su condición de ermitaño en busca del heroísmo cortesano- al protagonista

${ }^{311}$ López de Ayala afirma expresamente que la paloma del collar era blanca, color tal vez dominante en las vestes de la orden. En muchos lugares de la hagiografía castellana, el blanco es símbolo de pureza como sucede con aquellas palomas "más blancas que las nieves" que acompañan a las santas vírgenes hacia el Paraíso en el Poema de Santa Oria (c. XXXIIIc); cfr. Fernando Baños Vallejo, Simbología animal en la hagiografía castellana, en Actas del III Congreso Internacional de la Asociación Hispánica de Literatura Medieval, vol. I, Salamanca, 1994, p. 143. También cabe recordar la historia narrada por San Gregorio y recogida en el Libro de los exemplos por $A B C$ (c. 1435) de la muerte del santo monje del monasterio de Cample, de cuya boca Dios hizo salir una paloma para mostrar "con cuánta simpleza de coraçón éste le había servido"; SÁnChez DE VerCial, Libro de los exemplos por A.B.C, ob. cit., pp. 71-72 (n. 27). El infante Fernando de Antequera también escogió este color para su orden de la Jarra "a significança que dende en adelante que usasse de castidad"; Donatella Ferro (ed.), Le parti inedite della "Crónica de Juan II" di Alvar García de Santa María, Venecia, 1972, pp. 97-98; sobre los valores del blanco cfr. Pastoureau, Diccionario de los colores, ob. cit., pp. 82-83.

312 Andrés Mendo, De las ordenes militares, Madrid, 1681, p. 30.

313 Bernardo GIUSTINIANI, Historie cronologiche dell'origine degl'ordini militari e di tutte le religioni coualleresche infino ad hora instituite nel mondo, Venecia, 1672, pp. 274-275.

314 Así se expresan los autores del Suplemento al diccionario de teología del abate Bergier, Madrid, 1857, p. 675, apelando a "las crónicas de esta Orden [que] escribió en el siglo XVI el célebre P. Sigüenza, monje del Escorial, uno de nuestros clásicos mas apreciables".

315 Tema de amplio espectro que recorre las páginas de Yves Congar, Laic et laicat, en Dictionnaire de spiritualité, ob. cit., vol. 9, cols. 79-108; André VAUCHEZ, Les laics au Moyen Age. Pratiques et expériences religieuses, París, 1988. Agradezco a Luis Galván sus referencias a la literatura castellana; cfr. Ian MAcPHERSon, "Dios y el mundo": The Didacticism of El conde Lucanor, "Romance Philology", 24 (1970-1971), pp. 26-38; Inmaculada URZAINQUI, Más sobre la novedad didáctica de don Juan Manuel, "Bulletin hispanique", 92-2 (1990), pp. 701-728. 
de la Estoria del rrey Guillelme, que defiende la "carrera" del mundo hacia Dios sin abandonar la situación estamental ${ }^{316}$. El proceso alcanza un cierto climax espiritual a fines del siglo XIV, cuando se generan nuevos modelos caballerescos como los Nueve de la Fama que superaban los valores demasiado paganos de Arturo y Carlos Martel, y nuevas ceremonias como Los votos del pavón donde se mezclaba la exaltación del individuo con un renovado acento en la milicia cristiana ${ }^{317}$.

Finalmente, es preciso considerar el abandono de la estola o banda -ligado a la proeza individual- por la insignia del collar, que expresa la idea de "dependencia honorable" ligada al rey. Amador de los Ríos afirma que se trataba de un "Collar de Oro", metal que distinguía a los caballeros y volveremos a encontrar en los collares emblemáticos de Enrique III y Juan II $^{318}$. Su aparición en 1390 resultaba inédita en el espacio peninsular ${ }^{319}$ y pudo impulsar el despegue de esta insignia en Navarra donde Carlos III - casado con la hermana del rey castellano-adoptó un año después el collar de la Bonne Foy ${ }^{320}$, o en Aragón, donde Juan I fundó en 1392 su collar de la corona dobla que entregaba dorada a los caballeros y plateada a los escuderos ${ }^{321}$.

A la vista de estas consideraciones, la ceremonia segoviana admite varios niveles de análisis que partiendo de la emblemática nos ha llevado hasta la teología política del segundo Trastámara. Como un nuevo Luis de Tarento, Juan I buscó en la reinvención de su caballería una nueva reformulación de su poder que pasaba por la renovación espiritual y el mayor control de sus guerreros con vistas a la futura conquista de Portugal. Se trataba de un ambicioso proyecto de reconstrucción de la corte sobre el alveolo simbólico de la caballería y, en último término, de la Iglesia ${ }^{322}$. El monarca castellano rediseñaba de esta forma su propio sistema de representación en un marco

316 Juan Manuel CACHo Blecua, Amadis: heroísmo mítico cortesano, Madrid, 1979; y las páginas sobre la novelística caballeresca del período de Gómez Redondo, Historia de la prosa medieval castellana, ob. cit., vol. I. pp. 1126-1128.

317 Véase el trabajo citado de Francisco Bautista.

318 José Amador de los Ríos, Historia de la villa y corte de Madrid, vol. I, Madrid, 1860, p. 413.

319 Sus antecedentes inmediatos podrían ser los collares metálicos dotados de divisa que se difunden en la década de 1380, como el ideado por Juan IV de Bretaña en 1381 con su divisa del armiño y el mote $A$ ma vie, o el collar de vainas (la divisa de la cosse de genêt) distribuido en 1388 por Carlos VI de Francia; Lightвown, Mediaeval European Jewellery, ob. cit., pp. 258 y ss; НавLот, La devise, mise en signe du prince, ob. cit., pp. 415-418.

${ }^{320}$ Cfr. Ramos Aguirre, Cimeras, colores, divisas, ob. cit., pp. 361-374; y la original propuesta de Narbona, Le roi de la Bonne Foy, ob. cit., pp. 477-509.

${ }^{321}$ El infante Juan (I) adoptó a fines de la década 1370 la divisa de los "collares" que compartía con la reina y concedía a damas de su corte, antes de que el duque Jean IV fundara en 1381 la orden del Armiño, cuya insignia se considera el primer ejemplo conocido de collar metálico usado como divisa; cfr. Michael Jones, Les signes du pouvoir. L'ordre de l'Hermine, les devises et les hérauts des ducs de Bretagne au XV siècle, "Mémoires de la Société d'histoire et d'archéologie de Bretagne", 68 (1991), pp. 141-173; algunos datos de la divisa aragonesa en Josep Coroleu, Documents historichs catalans del sigle XIV: Colecció de cartas familiars corresponents als regnats de Pere del Punyalet y Johan I, Barcelona, 1889, pp. 111-112; Español Bertrán, Artistas y obras, ob. cit., pp. 270-271. Sobre la empresa de la correa fundada por el infante Martín entre 1385 y 1390, cfr. Henri BRESC, L'empresa de la Correge et la conquéte de la Sicile: Le royaume errant de Martin de Montblanc, "Anuario de Estudios Medievales", 23 (1993), pp. 197-220; sin embargo, sus estatutos de 1392 no aclaran el material de su insignia, probablemente elaborada con cuero, seda o algún metal.

322 Gómez Redondo, Historia de la prosa medieval, ob. cit., vol. II, pp. 1815-1816. 
que hacía emerger lo sagrado en el mundo ${ }^{323}$. No se trataba de una "sacralización" de su caballería, sino de una trasposición de realidades sagradas en la esfera temporal que ya había ensayado Alfonso XI en su autocoronación donde pretendió ligarse más directamente a la esfera de lo sagrado sin pasar por la mediación eclesiástica ${ }^{324}$. La fundación de la orden del Espíritu Santo refleja un análogo ideal "secularizador" al crear un espacio de poder con elementos de la liturgia cristiana bajo el dominio del rey. La diferencia es que ahora este espacio se proyectaba hacia las múltiples empresas políticas y religiosas impulsadas por este soberano reformador.

\subsection{LOS ESCUDEROS DE LA ROSA}

Junto a la orden y divisa del Espíritu Santo, los cronistas hablan de otra fundación análoga que pertenece al mismo proyecto caballeresco aunque en Segovia no gozara del mismo protagonismo litúrgico. Se trata de la orden de la Rosa, creada por Juan I como vía de promoción del cuerpo de escuderos que no habían recibido la investidura caballeresca y que, a partir de entonces, pudieron contar con su propio patrimonio simbólico adaptado a sus funciones militares y palatinas. López de Ayala afirma que el rey "fizo otra devisa que traían escuderos suyos, que decían la Rosa, é los que querían provar los cuerpos justando, o en otra manera, la traian". A diferencia de los caballeros del Espíritu Santo, mostraban su valor en la liza, participando en los espectáculos que les servían de entrenamiento durante su formación militar. Las justas eran por su carácter abierto el medio adecuado y más moderno de promoción frente a los torneos colectivos que practicaban los antiguos caballeros de la Banda y exigían la condición nobiliaria de sus participantes ${ }^{325}$.

Jerónimo Román la denomina orden de la Razón, precisando que estaba dirigida "para los escuderos e hijos dalgo" que mostraban ser "mas valiente(s) en la armas"326. La equivalencia entre hidalgo-escudero indicaría la necesidad de contar con cierta nobleza de origen aunque no se hubiera recibido aún la investidura ${ }^{327}$. Al fin y al cabo, los escuderos eran un grupo en evolución que servía de cantera de la orden del

${ }^{323}$ Cfr. Etienne AnHeIm, Lo sagrado en el mundo. La cultura cortesana del siglo XIVy su proyección, en Modelos culturales y normas sociales, ob. cit., pp. 311-330.

324 Tema desarrollado con diferentes matices - no desdeñables- por Bonifacio PALACIOS MARTín, Los actos de coronación y el proceso de "secularización" de la monarquía catalano-aragonesa (siglos XIII-XIV), en Etat et eglise dans la genese de l'etat moderne (J.-Ph. Genet; B. Vincent, coords), Madrid, 1986, pp. 113-128; José Manuel Nieto SoRia, Origen divino, espíritu laico y poder real en la Castilla del siglo XIII, "Anuario de Estudios Medievales", 27/1 (1997), pp. 43-100. Sobre los diferentes sentidos del concepto teológico de "secularidad" cfr. José Luis IlLANES MAEstre, La secularidad como elemento especificador de la condición laical, en Vocación y misión del laico en la Iglesia y en el mundo, Burgos, 1987, pp. 276-300; ID., Secolarità, en Dizionario enciclopedico di spiritualità, vol. III, Roma 1990, pp. 2278-2282.

325 Sobre esta temática cfr. Rosana DE ANDRÉs DíAz, Las fiestas de caballería en la Castilla de los Trastámara, "En la España medieval”, 8 (1986), pp. 81-108; Noel FALlows, Jousting in Medieval and Renaissance Iberia, Woodbridge, 2010.

326 Jerónimo Román, Republicas del mundo. Divididas en tres partes, vol. I, Medina del Campo, 1595, p. 431; Andrés Mendo señala que en ella "no entrauan sino los notoriamente nobles"; MENDO, De las ordenes militares, ob. cit., p. 30.

327 Ferrán Mexía, Nobiliario vero, ed. facsímil, Madrid, 1974, lib. II, f. IV. 
Espíritu Santo, como los donceles respecto a la orden la Banda. Su ámbito natural era por tanto el de los jóvenes aristócratas que se educaban en la corte desempeñando funciones ceremoniales, de vigilancia o aparato, y formaban una guardia personal que "acompañauan al Rey, quando salía a la guerra", llevando cada uno "su lança, que remataua en forma de Estandarte" de color "blanco liado de gules y suspendido de una cadena de oro" (Fig. 23b) ${ }^{328}$.

La representación de la divisa debía ser una Rosa, flor de densas evocaciones cristológicas y marianas muy difundidas en la época ${ }^{329}$. La lírica castellana la exaltaba como reina de las flores, símbolo de la aurora y de la primavera, que se identifica con la Virgen María en un marco de finalidad, de logro absoluto y perfección ${ }^{330}$. Juan I mostró por la Madre de Dios una particular devoción ${ }^{331}$, que pudo llevarle a poner a sus escuderos bajo su protección ${ }^{332}$ para inspirarles la "generosa animosidad y de constancia frente a los abatimientos de la fortuna" ${ }^{333}$. La rosa también podía asumir los valores cortesanos del Roman de la Rose como alegoría que guía a los jóvenes por el sendero del amor cortés, acechado por la maledicencia, la sospecha y el desdén ${ }^{334}$; una didáctica amorosa asumible por el ideal caballeresco de la nueva orden, como

${ }^{328}$ Mendo, De las órdenes militares, ob. cit., p. 30; la descripción del estandarte procede de Bruno Rigalt y Nicolás, Diccionario histórico de las órdenes de caballería, religiosas, civiles y militares de todas las naciones del mundo, Barcelona, 1858, p. 165. Resume estas noticias y añade una representación gráfica Giustiniani, Historie cronologiche dell'origine degl'ordini militari, ob. cit., pp. 275-276.

329 Además de la simbología mariana desarrollada por San Bernardo de Claraval, es preciso recordar la Rosa de oro, símbolo de Cristo y metáfora de lo efímero del poder, que el pontífice entregaba anualmente el día de Pentecostés al príncipe que se hubiera distinguido por favorecer a la Iglesia o extender la fe cristiana; Elisabeth CoRnIDES, Rose und Schwert im päpstlichen Zeremoniell von den Anfängen bis zum Pontifikat Gregors XIII, Viena, 1967; Agostino Paravicini Bagliani, Le chiavi e la tiara. Immagini e simboli del papato medievale, Roma, 1998, pp. 53-55; Anna Maria CorBo, Cantori, artisti e condottieri alla Corte dei Papi nel secolo XV, Roma, 1999, pp. 49-52; CirLot, Diccionario de símbolos, ob. cit., pp. 392-393; PÉREZ RioJA, Diccionarios de símbolos, ob. cit., pp. 373-374.

${ }^{330}$ Cfr. Vicente Beltrán, La cantiga de Alfonso XI y la ruptura poética del siglo XIV, "Crotalón. Anuario de Filología Española”, 2 (1985), pp. 259-273. Los poetas de cancionero también usan referencias de este tipo, como Garci Fernández de Gerena al llamar a la Madre de Dios "Virgen, flor de espina", o Ferrán Manuel de Lando al considerarla "preciosa margarita, lirio de virginidad, rosa de pureza"; sin olvidar otras referencias del marqués de Santillana, Juan de Mena o Jorge Manrique; cfr. Juan Pérez de Guzmán, La Rosa. Manojo de la poesía castellana, vol. I, Madrid, 1891, pp. 32-35.

331 Juan I hizo incluir en el protocolo de los privilegios rodados una frase que -según Suárez Fernández- no debe calificarse de formularia: "La Virgen gloriosa Santa María, a quien nos tenemos por señora y por abogada en todos nuestros hechos"; en SuÁrEz Fernández, Historia del reinado de Juan I, ob. cit., vol. II, pp. 24-25.

332 La Virgen como "caudillo" de la caballería aparece en la biografía de Pero Niño (1378-1453) redactada por DíEZ DE GAMÉs, El victorial, ob. cit., p. 209.

333 Pedro Joseph de AldazÁBal y Murguía, Compendio Heráldico, Pamplona, 1775, pp. 123-125.

334 La difusión de esta obra a fines del siglo XIV y su importancia como clave interpretativa de muchos poemas alegóricos del Cancionero de Baena es ponderada por Frederick Bliss LUQUIENS, The Roman de la Rose and Medieval Castilian Literature, "Romanische Forschungen", 20 (1907), pp. 284320. Véase también el Roman de la Rose en francés ilustrado con veintiocho miniaturas del siglo XIV conservado en la Biblioteca Nacional de España (Madrid), vitr. 23-11, que fue propiedad del caballero Alain de la Houssaye. Entrado ya el siglo XV, el marqués de Santillana consideraba que en el célebre poema "el arte de amor es tota inclusa"; Gerli (ed.), Poesía cancioneril castellana, ob. cit., p. 166. Sobre las discusiones en torno al Roman de le Rose en las Universidades de París y Toulouse en este período cfr. Huizinga, El otoño de la Edad Media, ob. cit., pp. 180-185. 
la cortesía lo había sido para la Banda ${ }^{335}$. Finalmente, la rosa también expresaba los valores de la juventud o el ascenso social que la literatura sapiencial otorga a aquel servidor de bajo linaje identificado con la flor que todos alaban "aunque es nacida de espinas" ${ }^{\prime 3} 36$.

La creación de una orden específica para los escuderos constituía una novedad que se ajusta a su creciente protagonismo militar. Pedro I les otorgó un encuadramiento como guardia personal compuesta de veinticuatro peones y doscientos de a caballo bajo las órdenes de un caudillo de los escuderos del cuerpo del Rey; "oficio muy principal en la casa del Rey" que porta en su titulación al concepto nuclear del imaginario cortesano: el cuerpo del rey ${ }^{337}$. En 1352 su titular era Diego Gómez de Toledo - I señor de Casarrubios y guarda mayor del rey- que actuaba en misiones de orden público y protección, ostentando el privilegio de portar el pendón real ${ }^{338}$. En el bando enriqueño, Juan González de Avellaneda lideraba a los escuderos de Vizcaya en la defensa de algunas plazas contra las tropas de Pedro I en 1351 y $1355^{333}$. Como había sucedido con Gómez de Toledo, desde 1383 era también alférez del pendón real ${ }^{340}$, escoltando al rey y probablemente dirigiendo a aquellos "cavalleros e escuderos que eran ordenados para la guarda de su cuerpo" ${ }^{341}$. En Aljubarrota estos hombres formaban una especie de guardia personal del monarca, portando su litera, protegiendo su huida y encargándose del pendón real que perdieron cuando el frente castellano se desplomós ${ }^{342}$. En este sentido, es posible que Juan I quisiera restaurar su prestigio dotándoles de una nueva poética caballeresca.

335 En su ordenamiento la fidelidad a la amada se erige en metáfora de la lealtad política del caballero de la Banda, vertebrando su corrección moral; cfr. KEEN, La caballería, ob. cit., p. 24; RoDRÍGUEZ Velasco, Ciudadanía, soberanía monárquica, ob. cit., pp. 203-204.

336 Con esta expresión se marca el contraste entre apariencia y realidad: "Non desalaban a la rosa aunque es nacida de espinas", SÁnchez de Vercial, Libro de los exemplos por A.B.C, ob. cit., pp. 148149 (n. 183).

$337 \mathrm{Su}$ desarrollo cortesano tuvo lugar en el reinado de Sancho IV con la formación de una tropa de 23 escuderos de a pie que actuaba como guardia personal del monarca, y debió consolidarse en el reinado de Pedro I con la creación de una "buena compaña, fasta doscientos de caballo de buenos escuderos", bajo el mando de un caudillo de los escuderos del cuerpo del Rey; Jerónimo de ZuRITA, Anales de la Corona de Aragón, Libro IX, cap. XVIII, vol. IV, Valencia, 1973, p. 362; cfr. Torres SANZ, La administración central, ob. cit., pp. 273-280; LADERO QUESADA, La organización militar de la Corona de Castilla, ob. cit., p. 223; SAlAzAR y Acha, La Casa del Rey de Castilla y León, ob. cit., pp. 329-330.

338 Véase por ejemplo el asalto a Aguilar (Córdoba) a principios de 1352 encomendado a Gómez de Toledo, que portaba el pendón real cuando los rebeldes lo rasgaron de un saetazo; Pedro LóPEZ DE AYALA, Crónica Del rey don Pedro, ed. C. Rosell, Biblioteca de Autores Españoles, vol. 68, Madrid, 1898, pp. 425 y 428-429; Luis Vicente Díaz Martín, Los oficiales de Pedro I de Castilla, Valladolid, 1975, p. 68; SAlazAr y Acha, La Casa del Rey de Castilla y León, ob. cit., pp. 547 y 558 . Más adelante el cargo debió cambiar de titular, pues en 1358 lo ocupa Juan Álvarez de Toledo, señor de Valdecorneja; Crónica Del rey don Pedro, año 1358, cap. XI, p. 486.

339 Enrique II mucho en la eficacia militar de los escuderos durante la batalla de Nájera (1367) y Juan I los incorporó como consejeros en calidad de vasallos junto a los caballeros en las Cortes de Burgos de 1379; Cortes de los antiguos reinos, ob. cit., vol. II, p. 286.

340 Marqués de Siete Iglesias, Los alféreces mayores del rey, "Hidalguía", 50 (1962), p. 146; Salazar y Acha, La Casa del Rey de Castilla y León, ob. cit., p. 441.

341 López de Ayala, Crónica de Juan I, ob. cit., año 1385, cap. XIV, p. 104.

${ }^{342}$ Años después Diego de Valera justificaría su reemplazo por considerarla enseña de dignidad y no de linaje; cfr. Schramm, Las insignias de la realeza, ob. cit., pp. 70-71. 
Sea como fuere, el cuerpo de escuderos se afianzó en la corte, distinguiéndose de otras guardias palatinas como los ballesteros - tan activos en tiempos de Alfonso XI y Pedro $\mathrm{I}^{343}$ - o los donceles que formaban la cantera de la Banda. González de Avellaneda debió encargarse de su encuadramiento bajo la Rosa Trastámara, pues conservó su oficio hasta su fallecimiento en 1393 en que fue sustituido por su primogénito Pedro Núñez de Avellaneda (1393-1415), y éste por su hijo Juan de Avellaneda (1415-1426). Con el tiempo los escuderos no perdieron su vinculación

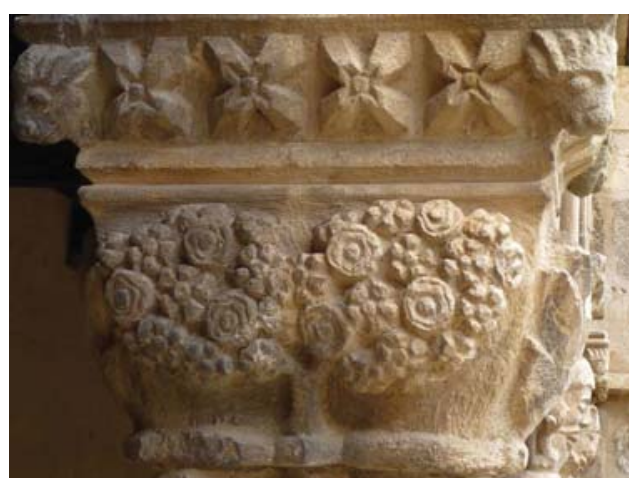

Fig. 26: Floración de Rosas de Catalina de Lancaster. Capitel del Claustro. Monasterio de Santa María la Real de Nieva (Segovia). con la emblemática regia pues en 1446 les dirigía Carlos de Arellano, perteneciente a la familia que patrimonializaba el cargo de alférez del pendón de la divisa, sin que podamos precisar la morfología de este signo ${ }^{344}$.

Desde el punto de vista emblemático, la flor Trastámara pudo inspirarse en la rosa Lancaster, difundida en Castilla a raíz del matrimonio del primogénito Enrique con Catalina Lancaster en 1388. Lo mismo había sucedido poco antes cuando João de Avis adoptó la divisa floral del espino (pilriteiro) por influencia de su esposa Felipa de Lancaster. La rosa de los mercenarios ingleses -denominados caballeros rosas durante el conflicto sucesorio ${ }^{345}$ - se convertía ahora en signo de la concordia anglo-castellana exhibido quizá por los justadores que intervinieron en las fiestas nupciales ${ }^{346}$. Años después Catalina representará su flor lancasteriana en los capiteles del monasterio de Santa María la Real (Fig. 26) mientras difundía el collar de la Jarretera entre sus fieles ${ }^{347}$. En el siglo XIX Vicente Arbiol y Rodríguez, imaginó el collar Trastámara como una sucesión de rosas doradas, grandes y pequeñas en el retrato de Juan I de Castilla (1848) (Fig. 27) ${ }^{348}$. Su color emblemático sería el rojo de la flor inglesa, asumiendo los valores de "magnanimidad o grandeza de coraçon" propios de esta tonalidad que también asignaba a su estandarte Bruno Rigalt ${ }^{349}$. Su combinación con

${ }^{343}$ Díaz Martín, Los oficiales de Pedro, ob. cit., pp. 49-50; Torres SAnZ, La administración central, ob. cit., pp. $278-280$.

${ }^{344}$ Sobre el cuerpo de escuderos de a caballo y los escuderos de a pie en la corte de Juan II cfr. CAÑAS Gálvez, La cámara de Juan II, ob. cit., p. 121.

${ }^{345}$ Cfr. Pérez de Guzmán, La Rosa. Manojo de la poesía castellana, ob. cit., pp. 34-35.

346 Ayala señala que Juan I premió a algunos de ellos con sus propias joyas (¿emblemáticas?); López DE Ayala, Crónica de Juan I, ob. cit., año 1388, cap. IV, p. 121.

347 Fernández de CóRdova, El cordón y la piña, ob. cit.

${ }^{348}$ Sobre este lienzo véase la nota anterior.

349 En su Vocabulario Alonso de Palencia señala que la rosa "es manera de flor dicha rosa por tener color bermeja [...] Rosa de color quermesí muy vistosa et fermosa"; en Nuevo tesoro lexicográfico, ob. cit., vol. IX, pp. 8596-8597. Diego de Valera también indica en su Tratado de los rieptos y desafíos (c. 1458-1567) que "el colorado, en los elementos asimesmo, es comparado al fuego: a cosas elementadas, 


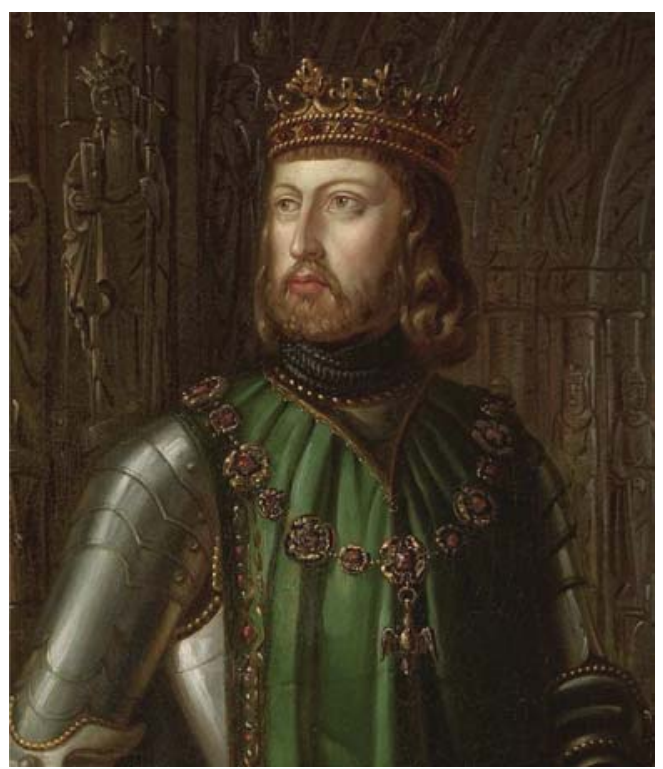

Fig. 27: Retrato de Juan I, elaborado a mediados del siglo XIX, portando un collar que integra las rosas y la paloma (como pinjante), divisas fundadas en 1390. Juan I de Castilla (detalle), Vicente Arbiol y Rodríguez. 1848. Museo del Prado (Madrid) el blanco del Espíritu Santo permitía además reproducir el bicromatismo de las armas reales castellanas siguiendo una tendencia a mantener los colores regios como sucede en el escudo de la Banda y en la emblemática posterior ${ }^{350}$.

El experimento de Juan I no llegó demasiado lejos. Su repentino fallecimiento tres meses después truncó aquel proyecto que fue inmediatamente arrinconado: "no se troxieron más aquellas devisas, e no fablaron dello", escribe el canciller Ayala ${ }^{351}$. Más modernamente Diego de Colmenares apostilló: "Todo pereció en flor, como su dueño", lamentando la extinción de aquella iniciativa "de grandes aumentos, porque lo merecían el intento y fundador" 352 . Este deliberado abandono levanta sospechas sobre la oposición de determinados grupos de grandes, refractarios al ordenamiento de lanzas o vinculados a la orden de la Banda, que veían con recelo el ascenso

de estos nuevos caballeros procedentes probablemente de las clases urbanas como los emergentes procuradores de las ciudades con voto en Cortes $^{353}$. La minoría de Enrique III les permitió hacer valer sus reivindicaciones impidiendo cualquier otra iniciativa fundacional pues el rey Doliente se limitó a adoptar una divisa personal que no se materializó en ninguna orden ${ }^{354}$.

Sin embargo, contamos con algunas noticias sobre la posible vigencia de los collares de Juan I y su ostentación con la Banda. Es el caso del condestable Ruy López Dávalos a quien Villasandino elogiaba hacia 1399 como «bien digno e mereçedor / del Collar [¿el de Juan I o el de Enrique III?] e de la Vanda» al comentar sus hazañas contra el enemigo portugués en singular coherencia con el mensaje emblemático de

a los relámpagos, al rubí al aranbre, a la rosa: en virtudes a la magnanimidad o grandeza de coraçon"; Prosistas castellanos del siglo XV, ed. P. F. Rubio, Madrid, 1959, p. 110; los valores positivos del rojo en la simbólica medieval (vida, amor, alegría) parten de su asociación al rojo redentor de la charitas, es decir, de la sangre derramado por y para Cristo; cfr. PAstoureau, Diccionario de los colores, ob. cit., pp. $69-70$ y $259-262$.

${ }^{350}$ Sobre la combinación del blanco y el rojo como colores de la Reconquista cfr. GonzÁLEZ ARCE, El color como atributo simbólico del poder, ob. cit., pp. 103-108.

${ }^{351}$ López de Ayala, Crónica de Juan I, ob. cit., cap. XVIII, p. 143.

${ }_{352}$ Colmenares, Historia de la insigne ciudad de Segovia, ob. cit., cap. XXVI, p. 525

${ }^{353}$ Michel García, Crónica anónima de Enrique III de Castilla (1390-1391), Madrid, 2013; pp. 169 y ss.

${ }^{354}$ Cfr. Fernández de CóRdova, El cordón y la piña, ob. cit. 
las fundaciones de $1390^{355}$; o la "Vanda e Collar" que Villasandino se enorgullecía de haber recibido de Juan $\mathrm{I}^{356}$, considerándolas expresión de la vida caballeresca laica: "Pues yo dexo el çendal, / Oro e Vanda e aun Collares / andaré royendo altares por monge conventual" 357 .

Como es sabido, el infante Fernando recuperó la idea de su padre creando en 1403 su propia orden y divisa de la Jarra y el Grifo ${ }^{358}$. Se conjugó entonces la insignia del collar con una estola, introduciendo algunos cambios cromáticos y para distinguirla y equipararla sutilmente a la Banda. El infante mantuvo el color blanco de la paloma Trastámara, empleó un nuevo motivo floral, el lirio o azucena, que comparte con la rosa su evocación mariana, y añadió el grifo que recibiera de su padre en 1390. Para solemnizar su fundación, se repitió el esquema celebrativo segoviano con la presentación de los estatutos y la entrega de los collares en la iglesia de Santa María la Antigua en Medina del Campo (Valladolid), centro de sus señoríos. Sin embargo, nadie podía prever entonces el éxito de aquella orden caballeresca que proporcionó un fabuloso aparato propagandístico al infante en su meteórico ascenso como regente de Castilla (1406-1416) y rey de Aragón desde su elección en Caspe (1412-1416).

Algunos autores consideran que los sucesores de Juan I debieron restaurar la orden del Espíritu Santo introduciendo ciertas modificaciones en su insignia, que ha sido identificada en algunos sepulcros o monumentos de la segunda mitad del siglo $\mathrm{XV}^{359}$. En estas representaciones, el collar estaría formado por una serie de nubes estilizadas -semejantes a las que rodean el nimbo místico del Cielo-, con varias "T" repetidas a lo largo del collar y un doble colgante formado por una paloma explayada boca abajo unida a un león pasante por medio de una cruz patada inscrita en un círculo. Sin embargo esta insignia debe tratarse del distintivo de la Fraternidad de San Antonio

355 Dezir contra un portugués compuesto en 1399; en Cancionero de Juan Alfonso de Baena, pp. 103-104; sobre el personaje y la datación del poema cfr. Óscar PEREA Rodríguez, "El Cancionero de Baena como fuente historiográfica de la Baja Edad Media castellana: el ejemplo de Ruy López Dávalos", en Jesús L. Serrano Reyes (ed.), Cancioneros en Baena. Actas del II Congreso Internacional Cancionero de Baena. In memoriam Manuel Alvar, vol. I, Baena, 2003, pp. 293-334.

356 Se trata del relato autobiográfico contenido en su dezir querellándose al señor Rey de los otros que usan d'este arte, que debió componer entre 1419 -fecha de la mayoría de edad de Juan II- y el fallecimiento del poeta hacia 1424; en Cancionero de Juan Alfonso de Baena, ob. cit., pp. 253-254, donde se ofrece una datación (1406) que debería corregirse teniendo en cuenta las precisiones de Porro Girardi, que considera a Juan II el auténtico destinatario del poema; Nelly Raquel PorRo GIRARDI, El ingreso de Villasandino en la caballería, "Cuadernos de historia de España", 61-62 (1977), pp. 376378; Carlos Mota Placencia, La obra poética de Alfonso Alvarez de Villasandino, Bellaterra, 1992, pp. 823-824.

357 Se trata del Dezir para el Rey nuestro [señor] e por manera de reqüesta contra los trobadores, que debió componerse entre 1406 y 1417; en DutTon y GonzÁlez CuencA, Cancionero de Juan Alfonso de Baena, ob. cit., pp. 226-227. Para datar el poema me baso en la identificación de los personajes citados: el "Rey de vista angelical" [el jovencísimo Juan II], el "Mariscal" [seguramente el mariscal Pedro García de Herrara (1390-1455) nombrado por Enrique III], el “de Estúñiga” [Diego López de Estúñiga (1350-1417) Justicia Mayor y tutor del joven Juan II] y "Cañizares” [Álvaro de Cañizares, criado de la reina Catalina de Lancaster en 1418].

358 Véase la bibliografía anteriormente citada.

359 Boulton, The knights of the crown, ob. cit., pp. 327-328 y 483-484. Algunas estelas en Ottried NeUBeCKer, Le grand livre de l'heraldique: l'histoire, l'art et la science du blason, París, 1993, pp. 215 y 218. 


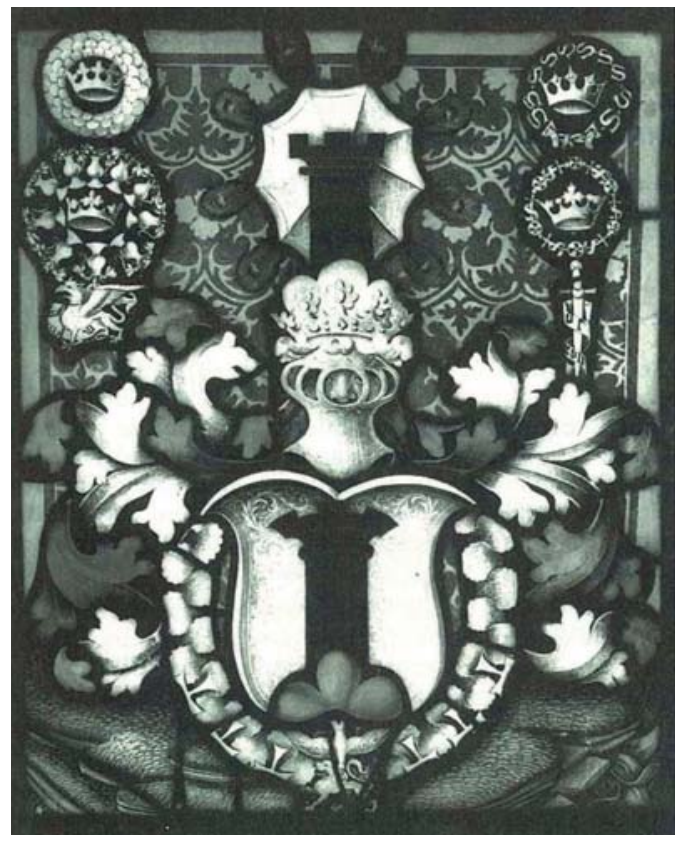

Fig. 28: Vidriera con las armas de Conrad de Scharnachtal, rodeadas de sus órdenes y divisas (posterior a 1474). Iglesia parroquial de Saint André de Hilterfingen (Thoune-Suiza). El collar que orla el escudo ha sido identificado con el collar del Espíritu Santo, aunque puede tratarse del Collar de San Antonio de Cleves. Fotografía: Werner Paravicini

(Bruederschap Sent Anthony) fundada después de 1430 por Adolf II y IV de la Marck para reunir a los príncipes de Alsacia bajo la influencia del ducado de Borgoña (Fig. $24 \mathrm{~b})^{360}$.

Entre los posesores de esta insignia se cuentan caballeros suizos como Louis de Diesbach $(† 1453)$-miembro de una importante familia de Berna- que pudo recibir el collar del Espíritu Santo durante su viaje a la península Ibérica entre 1447 y $1450^{361}$. También se ha conjeturado su recepción, junto a la Banda y el collar de Escama, por Conrad de Scharnachtal a su paso por Castilla en el verano de 1447, tal y como figura en su vidriera armoriada de la iglesia de Saint-André de Hilterfingen (posterior a 1474) (Fig. 28) ${ }^{362}$. Finalmente, el mismo collar se representa en la lápida sepulcral de

${ }^{360}$ Véase el capítulo que le dedica Boulton, The knights of the crown, ob. cit., pp. 576-581.

${ }^{361}$ Las ediciones del relato de su viaje y la referencia a las vidrieras de Worb y Pérolles que lo recuerdan en Werner Paravicini, Seigneur par l'itinérance? Le cas du patricien bernois Conrad de Scharnachtal, en L'itinérance des seigneurs (XIVE-XVIe siècles) (A. PARAVICINI Bagliani; E. Pibiri; D. REYNARD, eds.), Lausanne, 2003, p. 41; el mismo collar identificado con el del Espíritu Santo también figura en la lápida de Nicolas von Diesbach; reproducida en Boulton, The knights of the crown, ob. cit., p. 328; y en otra representación caballeresca de Nicolas von Diesbach reproducida en Ottfried NeUBECKER, Wappenkunde, München, 1980, p. 206.

362 Paravicini, Seigneur par l'itinérance, ob. cit., pp. 52-53; donde el autor identifica en la vidriera el collar castellano del Espíritu Santo orlando las armas centrales con una paloma explayada y un león 
un caballero desconocido en Neuberg (Fig. 29) ${ }^{363}$. Aunque estas atribuciones no se han confirmado aún, la perpetuación de la divisa de Juan I no sería extraña en una dinastía acostumbrada a mantener-al menos en una generación- la emblemática heredada, como sucedió con el cordón de San Francisco de Enrique III, la Escama de Juan II o las granadas de Enrique IV, conservadas e incluso otorgadas por sus respectivos sucesores. Todavía en 1672 Bernardo Giustiniani aseguraba que se conservaba la memoria de estas órdenes en Andalucía y otras zonas de Castilla, aunque no mantuvieran las obligaciones de sus estatutos ${ }^{364}$.

\section{CONCLUSIONES}

La historiografía ha interpretado el reinado de Juan I como la piedra angular del establecimiento de los Trastámara en el trono castellano. Si las reformas emprendidas coadyuvaron a ello, no es menos cierto que la política emblemática del rey enriqueció los sistemas de representación regia sosteniendo la legitimidad y el prestigio de la dinastía. En continuidad con la herencia recibida de Enrique II, el segundo Trastámara enriqueció su patrimonio iconográfico e impulsó una mejor adaptación de las divisas a su proyecto político aprovechando su potencial simbólico y su valor estético. No se trataba de una labor de maquillaje, sino de dotar a la nueva monarquía de sus propios signos identificativos y una simbólica caballeresca capaz de galvanizar a la aristocracia castellana bajo su sombra.

Este proceso de construcción identitaria no tuvo una evolución lineal. Como un Jano bifronte, el sistema emblemático de Juan I nació como un recurso legitimador que miraba al pasado de Alfonso XI (orden de la Banda) y a un futuro de unificación y victoria que derivó hacia perfiles más religiosos en los últimos años del reinado. Su gobierno comenzó bajo el signo de la Banda, que coincidía con el orden de Enrique II basado en el apoyo nobiliario. Juan I dotó de fuerza legal a sus estatutos y buscó nuevos soportes iconográficos que reforzaron su imagen caballeresca.

pasante como colgantes, y armoriada (posterior a 1474) en p. 55; las referencias documentales en pp. 56-62.

363 Una reproducción en Boulton, The knights of the crown, ob. cit., p. 483.

${ }^{364}$ Giustiniani, Historie cronologiche dell'origine degl'ordini militari, ob. cit., p. 276. 
Durante su reinado enriqueció la emblemática zoomórfica paterna que se movía entre las modas aristocráticas y los vaticinios proféticos (dragón, grifo) aportando nuevas criaturas para expresar sus proyectos de conquista (halcón) y ensayando nuevos soportes (sellos, enseñas y tal vez monedas) para aumentar su visibilidad. Aquella pulsión emblemática sufrió un serio revés en los campos de Aljubarrota con la pérdida de sus enseñas y la frustración de los valores proféticos que vehiculaban. Fue un punto de inflexión que hizo bascular la emblemática regia hacia motivos más religiosos que respondían a la interpretación providencialista de la tragedia. Comenzó entonces la segunda etapa de la parábola caballeresca de Juan I que finaliza en 1390 con la fundación de las divisas del Espíritu Santo y la Rosa. Una medida que despojó a la Banda del monopolio caballeresco y dotó a los nuevos emblemas de una función integradora, reuniendo a los grupos aristocráticos dispuestos a colaborar en su proyecto de reconstrucción monárquica con sus correspondientes reformas militar, religiosa y administrativa impulsadas en las Cortes de Guadalajara. La ceremonia celebrada en Segovia expresaba, con su ritual y su teología política, la concepción descendente del poder que consolidaba los derechos dinásticos y fortalecía los vínculos del rey con su caballería en la línea secularizadora emprendida por Alfonso XI.

Las medidas de Juan I fueron más un boceto incoado que una obra terminada. Sin embargo, constituyeron una fuente de inspiración fundamental para sus sucesores. Enrique III (1393-1406) conservó la inspiración religiosa de su emblemática adoptando el cordón de San Francisco como divisa personal e insignia para reunir a su clientela. Su hermano el infante Fernando de Antequera retomó la iniciativa fundacional de Juan I al crear la orden de la Jarra con una dimensión fuertemente propagandista, y probablemente impulsó la creación de la orden y divisa de la Escama para dotar el jovencísimo Juan II (1406-1454) de sus propios cuadros aristocráticos en el difícil interregno que se avecinaba.

En 1409 la difusión de las divisas reales había llegado a tal punto que fue necesario prohibir su uso abusivo. Era el final de un proceso de maduración que desembocará en los dispositivos emblemáticos de Catalina de Lancaster, los murales de Juan II y la apabullante exhibición heráldica de los Reyes Católicos. En el origen de esta transformación se hallaba la herida abierta por una derrota militar que no dejará de supurar durante el siglo XV y que en el ánimo de Juan I adquirió una particular dignidad. Tal vez sea ésta la peculiar grandeza de un rey que en su empeño por destejer el tiempo, y de modificar el pasado, convirtió su propia emblemática en un sugestivo ejemplo de superación política y espiritual. 